\title{
Cooperation, fairness and civic capital after an earthquake: Evidence from two Italian regions
}

\author{
Francesca Pancotto ${ }^{\mathrm{a}}$, Francesca Giardini $^{\mathrm{b}}$, Simone Righi $^{\mathrm{c}}$ \\ a Universita' di Modena e Reggio Emilia \\ ${ }^{b}$ University of Groningen \\ 'Universita' Ca' Foscari
}

\begin{abstract}
Natural disasters put an enormous strain on civic capital, which can result in a decrease in trust and cooperation in the affected communities. However, the existing level of civic capital can buffer the effects of the disaster, determining completely different dynamics even in neighboring regions. In order to investigate the determinants of long-term resilience to natural disasters, we designed a 2x2 lab in the field experiments conducted in Marche and Emilia-Romagna, two Italian regions that were affected by major earthquakes in 2016 and 2012, respectively. We collected data in neighboring and comparable municipalities that were affected or not by earthquakes and we compared inhabitants' prosocial choices in a Public Good Game and a Distribution game. Our results show that people affected by the earthquake were more prosocial in general, while at the individual level the effect of the earthquake is present only in people who suffered material damage via their increased desire for redistribution. We also show that civic capital was not different among regions or among people living inside or outside the earthquake area.
\end{abstract}

Keywords:

\section{Introduction}

Communities in which individuals help each other out, trust each other, and uphold norms of cooperation are more resilient. Social capital, norms and trustworthiness are pivotal to achieving cooperation and solving collective action problems, and they play a major role both in the immediate aftermath of disasters and even more so in the following months and years, i.e., during the reconstruction period (Nakagawa and Shaw, 2004). Regardless of the kind of hazard, being it natural like an earthquake or man-induced like the explosion of a chemical plant, the physical destruction can be so profound to affect the fabric of society. Disasters can jeopardize cooperation and drastically reduce the ability of the community to bounce back to the pre-disaster situation in terms of livability and individual well-being. With the impact of disasters and hazards around the globe steadily growing (UNDRR, 2019), it becomes essential to understand the determinants of resilience and the factors affecting the way in which communities cope with disasters and what makes some of them more successful than others (Loenhout, 2020).

Resilience, i.e., the ability of actors to bounce back and recover from crises, has been conceptualized in several ways (see Tierney 2006), and the literature points to various aspects that can be linked to the ability of communities to go back to pre-disaster levels of cooperation (Renschler et al., 2010; Cutter et al., 2008). Despite a growing amount of work on disaster resilience, there is still a limited understanding of its determinants. Moreover, variation in post disaster resilience across communities, countries and situations is striking: research on natural disasters show that they might create social divisions within communities (e.g., Aeta after the eruption of Mt. Pinatubo, the Philippines in 
1991, as mentioned by Nakagawa and Shaw 2004), as well as induce exceptional levels of self-sacrifice and unconditional help (Imperiale and Vanclay, 2019; Aldrich and Meyer, 2015).

Resilient communities tend to be characterized by high levels of social capital. Aldrich (2012) shows that in major disasters across the globe, high levels of social capital served as 'the core engine of recovery' (p. 15). Social capital helps explaining how communities recover after disasters, but it is difficult to link it to individual choices and to their collective outcomes. On the other hand, attempts to test the effects of natural disasters on individual behaviors like cooperative choices in more controlled settings with economic games, lab-in-the fields and surveys, report incoherent results (Whitt and Wilson, 2007), showing how difficult it is to define and measure post disaster resilience in a simple and straightforward way.

In this work, contribute to the literature on post-disaster resilience by conducting an empirical study on cooperation and fairness in seven municipalities in central Italy. Three of them were affected by two different earthquakes in two different moments, whereas the remaining four municipalities were close but unaffected. By means of lab-in-thefield experiment and survey questions we investigated how resilience, which we operationalized as a combination of cooperation and fairness, varied across communities which experienced severe earthquakes in two neighboring Italian regions. Emilia and Marche were affected by a sequence of earthquakes in 2012 (Emilia) and 2016 (Marche), but within each region the distribution of casualties, impact and economic damages were heterogeneous. Thanks to this difference, we can compare the decisions of citizens residing outside the seismic area with those of people directly affected by the disaster, both within and between regions. Although being close to each other, Marche and Emilia differ in terms of GDP, economic activities and characteristics of the territory, thus making this comparison especially interesting. Furthermore, while cross-country comparisons are quite common in the disaster literature, a more limited number of contributions addresses within-country comparisons of disasters' effects (duPont and Noy, 2015; Russo and Pagliacci, 2019). Moreover, in the economic and sociological literature there is a tradition of studies on the variation in cooperation and social capital among distant cultures (Herrmann et al., 2008; Henrich et al., 2001, 2010; Grimalda et al., 2015) as well as between Italian regions that are geographically and culturally distant, e.g., the North-South divide (Battiston and Gamba, 2016; Bigoni et al., 2019; Helliwell and Putnam, 1995; Ichino and Maggi, 2000; Putnam et al., 1994). Experimental evidence points to the existence of a substantial differences in behavior between participants in economic experiments in a representative sample of Northern and Southern Italy in terms of their ability to achieve and sustain cooperation (Bigoni et al., 2016), even if the reasons for this difference are still not fully understood (and historical analysis prove that the difference is more multifaceted than it is usually portrayed, cf. Felice 2018; Felice and Vecchi 2015).

The aim of this paper is twofold. First, we intend to test whether norms of cooperation and fairness differ between people who were affected by an earthquake and people who lived nearby but did not suffer from it. We compare choices in a Public Goods Game (PGG) and in a Distribution Game (DisG) made by two groups of participants, those who experienced a series of earthquakes in 2012 and 2016 and those who lived outside the affected area. Second, we explore the determinants of cooperative behavior and fairness, two important components of resilience, at the individual level, with the aim to identify the elements that were influenced by the event. We investigate individual characteristics (age, gender, occupation), the earthquake experience (amount of damage and housing conditions), and the characteristics of the region, while controlling for civic capital, identified in the literature as a fundamental component of resilience. We 
control for long term persistence using civic capital indicators, such as survey questions about electoral participation and blood donation (Guiso et al., 2004) and self-reported measures of generalized trust.

The rest of the paper is organized as follows. First, we introduce a theory of resilience as a combination of cooperation, fairness and civic capital. Second, we delineate the context, describing the territories, their characteristics and briefly sketching their histories. Third, we describe the experimental setup and procedure. We then present the results of the study and, finally, we discuss conclusions and future work.

\section{Theory}

If a system exhibits the capacity 'to return to equilibrium after a displacement' (Norris et al., 2008), then that system is considered resilient. A resilient community is one in which its members actively contribute to (re)build the tangible and intangible environment after an external shock or a crisis. Investing time and resources in helping others, volunteering, and participating in community life are individual choices that can definitely benefit one's community, and they can all be described as social dilemmas, in which individuals' benefit is at odds with collective welfare (Ostrom, 1990). Resilience does not only stem from individual preferences for helping others, but it is also the result of community norms and values that create a trusting and supportive environment. In this work, we test separately three determinants of resilience: cooperation and fairness are tested directly by means of individual choices in labin-the-field experiments, while civic capital is measured in terms of responses to a post-experimental survey. We measure contributions in a PGG and allocations in a DisG as measures of individual preferences for cooperation and fairness respectively, whereas we use survey questions about socio-demographic elements, trust and embeddedness as indications of civic capital, which is closely linked to community resilience. We conceptualize resilience as a compound concept resulting from the interaction between three elements: a) cooperation, intended as a willingness to contribute to the collective good at a cost for oneself, b) fairness, intended as a preference for equitable outcomes, and c) civic capital. Since cooperation and the ability to contribute to the rebuilding of the community are key aspects of resilience (Norris et al., 2008), in this study we look for variations in these three facets as an effect of exposure to earthquakes in Italy. More specifically, we are interested in comparing individual behavior of participants living in small towns and villages hit by earthquakes and participants living in the nearby areas that were not affected.

Cooperation. Propensity to exhibit prosocial behavior increases during or immediately after a disaster (Jonas, 2012; Eränen and Liebkind, 1993; Kaniasty and Norris, 1995), but the behavioural patterns become less clear over time. Indeed, while the danger and emotional distress experienced during and in the aftermath of disaster makes cooperating with others more likely to happen, these prosocial feelings can fade away and the individuals and their communities will be unable to experience a full recovery. In fact, individual attitudes and social mechanisms can loose their influence when individuals need to focus on primary needs after a disaster (finding shelter, protecting their families, finding food, etc.), and this makes cooperation even more brittle. On the other hand, the common experience of a disaster can shape an in-group identity that will make individuals more willing to cooperate because of their previous cooperative experiences. Previous studies of natural-disaster victims provide contrasting evidence about their effects on cooperative choices. Individuals affected by natural disasters show significantly less trustworthy behavior (Fleming et al., 2014) but exhibit greater trust in both experiments (Cassar et al., 2017) and survey studies with hypothetical scenarios (Veszteg et al., 2015; Rao et al., 2011). 
The case of Italy is especially interesting because the institutional context provides a natural way to isolate the effects of the earthquake. Municipalities within the seismic area and their residents receive government subsidies in different forms, and the affected households receive subsidies to rebuild or fix damaged houses, which can be interpreted as an exogenous difference. By comparing the behavior of people living in similar and close municipalities inside or outside of the area institutionally recognized as affected by the earthquake we want to identify the effect of the disaster on contributions to a PGG. There are two alternative hypotheses that we will test: Hp1a. Individuals living in the affected are are more willing to contribute to the common good because of the positive effect of the disaster in enforcing a norm of mutual help and cooperation. However, cooperation is brittle and enforcing it, especially in the years following a disaster, can be difficult. Material damage, physical and psychological trauma, and lack of support are all factors that can make cooperation difficult, while increasing individuals' focus on themselves and their needs. In areas affected by major disasters a feeling of helplessness and the psychological consequences of trauma can make people more inward looking and proself, therefore cooperation to a common good should be lower than in areas that were not affected. Hp1b. Individuals living in the affected are are less willing to contribute to the common good because of the negative effect of the disaster as enforcing proself behaviors.

Fairness. Fairness is the extent to which individuals are willing to engage in distributive justice (Mayer, 2007), and it plays a important role in motivating prosocial behaviors (Fehr and Fischbacher, 2004; Fehr et al., 2002). In societies in which wealth is predominantly attributed to merit and individual willpower, the demand for redistribution is lower (Alesina and Angeletos, 2005). On the contrary, when people believe that luck plays a major role in determining people's outcomes, then there is a more positive attitude, and a request for, redistributive policies (e.g. Alesina and Angeletos 2005; Alesina and Ferrara 2005; Bénabou and Tirole 2006). Fairness has been studied in relationship with disasters because the desire to equalize outcomes can result in cooperative choices and less inequalities. Gualtieri et al. (2018) investigated the relationship between a natural disaster (the L'Aquila earthquake, one of the more disruptive earthquakes occurred in Italy since 1980) and the demand for redistribution. Their results show that individuals who experienced the earthquake have a significantly stronger preference for redistributive policies.

This preference can also be linked to the amount of property damage suffered, which is known to affect prosocial choices (Vardy and Atkinson, 2019). We thus hypothesize that Hp2a. Individuals who were affected by the earthquake are more inclined to engage in redistribution as a compensation Hp2b. Individuals' willingness to engage in redistribution is predicted by the size of material damage suffered.

Civic capital. Studies on post-disaster recovery consistently show that the difference between communities that manage to rebuild themselves effectively and those that are unable to do so can be found in social capital (Aldrich, 2012; Aldrich and Meyer, 2015). In Putnam's words, social capital 'refers to connections among individuals - social networks and the norms of reciprocity and trustworthiness that arise from them. In that sense social capital is closely related to what some have called 'civic virtue'. The difference is that 'social capital' calls attention to the fact that civic virtue is most powerful when embedded in a dense network for reciprocal social relations' (Putnam et al., 1994).

By analyzing different kinds of data coming from communities hit by major disasters (the earthquakes in Tokyo in 1923 and Kobe in 1995, the Indian Ocean Tsunami in 2004 and the Hurricane Katrina in 2005), Aldrich (2012) and Aldrich and Meyer (2015) explained the differences in recovery by the role of social capital across diverse societies, cultures and economic backgrounds. 
Guiso et al. (2011) propose the concept of 'civic capital' as the 'values and beliefs that help a group overcome the free-rider problem in the pursuit of socially valuable activities'. The concept of civic capital emphasizes the importance of individuals' values and beliefs, their sharing and persistence over time, because they are passed on to community members through inter-generational transmissions, formal education, or socialization. Civic capital has been used to explain financial development in those contexts in which high civic capital generates high generalized trust which, in turn, leads to the signing of financial contracts (Guiso et al., 2004). In a similar manner, civic capital supports cooperative choices that are necessary to rebuild material and immaterial communities after catastrophic events, and its persistence over time could explain the current variation between communities. Inter-generational transmission of civic capital can explain long-term within-country variation of cooperative behaviors. Bracco et al. (2015) report evidence showing that within country substantial variations in civic capital can be traced back to specific historical episodes, no matter how far back in time. They report data on the differences in civic capital between communities of Italians and Albanians following a unique and geographically concentrated immigration event in 16th century Italy. These so-called Arberesh communities are perfectly integrated in the Italian society, but they still display different behavior consistent with an original tradition of higher civic capital compared to the hosting Italian communities.

\section{The context}

Because of its existing vulnerabilities, Italy offers an interesting test bed for the study of post-disaster resilience. Also, the fact that Italy was unified only recently and there are still persistent differences across regions makes comparison between regions especially interesting. Together with persistent differences due to alternative historical developments, disasters contribute an additional dimension of variation within the same region by hitting close locations in different ways. This difference between affected and unaffected locations is very relevant, not only because of its immediate consequences but also for its long-term effects.

Marche and Emilia Romagna are neighboring regions in whose coastal areas runs undivided (Costa Adriatica) whereas the Apennines creates a natural boundary between the Po plain (Pianura Padana) in Emilia and the mountain rural areas in the inner Marche. Although close to each other, these two regions were historically belonging to different realms until the country unification in 1861.

These different realms were also characterized by different institutional settings, with Marche being part of the highly centralized Stato Pontificio, ruled by the pope, and Emilia being divided into small state-cities with a strong civic tradition and an active aristocracy. Secondly, most of the territory in Marche is mountainous and rural, with only 10 per cent of flat land and many small villages scattered across the Apennines. On the contrary, Emilia is mostly flat, which means that villages and towns have been always much more connected to bigger centers and among themselves. These geographical differences could partially explain the current economic divide between these regions. Emilia is a rich industrial area, with many small and medium sized enterprises (GDP per capita in 2017 was 35.323,80 Euros), whereas Marche's inhabitants main source of income is tourism, especially on the coast (GDP per capita of Marche Region in 2017 was 26.597,17 Euros). As much of the Italian territory, both Emilia Romagna and Marche are seismic areas, and both regions were hit by major earthquakes in the last few years. Between May and June 2012 a total of seven strong and destructive earthquakes hit Emilia-Romagna (damage estimated at around 12 billion Euros, 27 victims). In August and October 2016 Central Italy was hit by several major earthquakes, which caused a total 

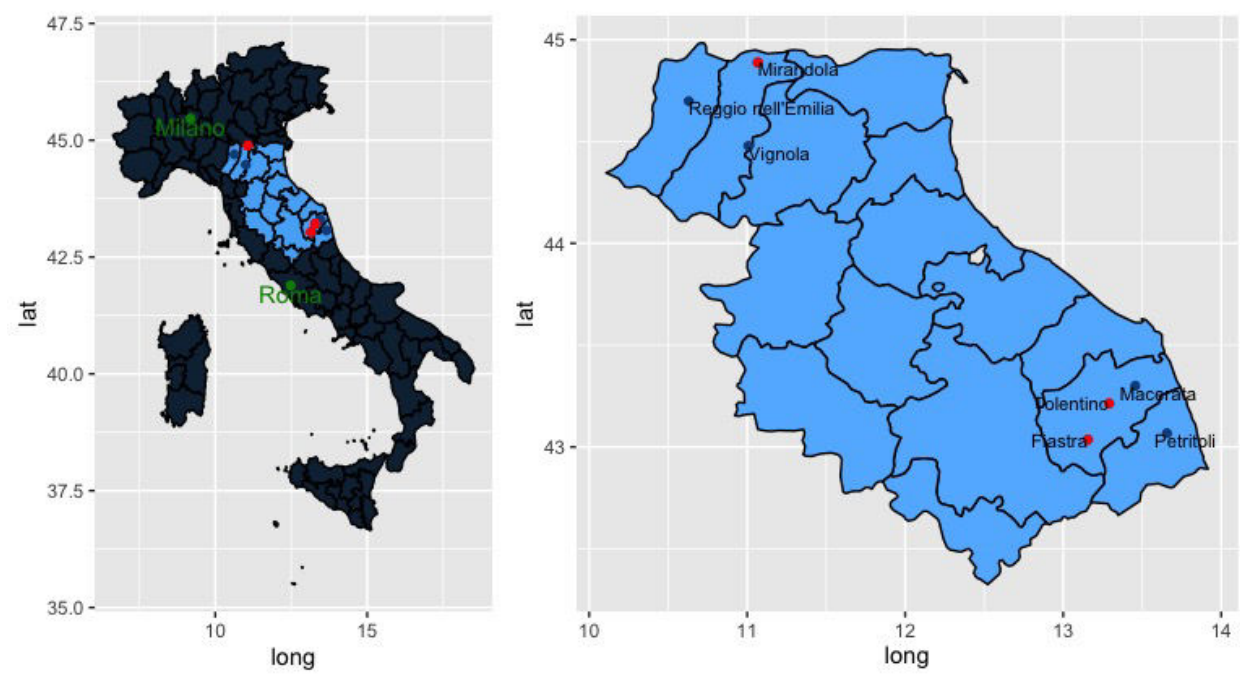

Figure 1: Left: map of Italy, dots identify locations of the experiments. Right: focus on center east area with locations indicated with coloured dots. Red dots are cities inside the crater, blue dots are cities outside the crater.

damage estimated in 27 billion euros and killed 299 people. Marche was one of the regions affected, and the number of people who were forced to leave their houses was 32000 (over a total of 39800 dislocated people in the four affected regions).

After an earthquake the Italian government makes an immediate estimation of the damages and it creates a sharp distinction between those parts of the territory that are to be considered affected areas and those parts that are not. This administrative distinction brings about many important consequences, because it determines the distribution of subsidies for individuals, households, and firms. Communities within the seismic area, cratere sismico in the Italian bureaucratic language, receive immediate aid and structural funding for rebuilding private houses and public buildings, whereas villages, towns and cities outside the area are not eligible for economic aid. This creates the condition for a comparison between damaged and undamaged communities within each of the two regions. On the basis of this distinction, we identified seven locations with varying features (see Fig. 1). For Emilia-Romagna, we chose Mirandola as city belonging to the seismic area, whereas Reggio Emilia and Vignola were locations outside it. Vignola is a smaller town and more comparable to Mirandola in terms of city size and structure, with respect to Reggio Emilia which is a larger city. For Marche, we selected Petritoli and Macerata as towns outside the seismic area and Fiastra and Tolentino as locations inside. Concerning town structure, Petritoli can be considered half way size between Fiastra, which is a tiny village on the mountains, and Tolentino, which is a medium size town with an industrial cluster and larger population.

Experimental sessions were held in easily accessible public locations (city councils, city library and classrooms ${ }^{1}$ ). Sessions were run between November 2015 and May 2019. We are aware that the selected municipalities are not totally comparable because of the existing differences between the distribution of the population in these two regions, their socio-economic history and geographical/geomorphic features. Nonetheless, we believe that these differences make our

${ }^{1}$ Details on the sessions are reported in Supplementary Material 
comparison even more relevant.

\section{Experimental design}

In order to test the effects of the earthquake on cooperation and fairness, we run a between-subject design in which we compared locations inside and outside the earthquake area. The planning of the experiment was conceived in response to Emilia Earthquake in 2012: however, sessions started only in 2016. By coincidence, several earthquakes hit Marche in 2016, thus allowing us to use the same structural design to collect data in Marche as well. This extension implicitly added a between-region comparison to the design, which required however to take into account regional-level elements that are potential confounding factors. We report a general description of locations features in Supplementary Material.

\subsection{General sample of the population}

We selected a sample from the general national population at the time of the experiment. The composition of our sample in terms of demographics and working conditions are reported in Table 1, together with indications of any difference between the experimental sample and the general population. The actual sample over-represents females, students and younger individuals and under-represents retired, inactive and older people, with respect to the Italian population as photographed by the 2019 census. Even if our sample is not fully representative, it still incorporates a wide spectrum of the population. The total number of participants recruited was 252, distributed across locations as reported in Table 2 .

\begin{tabular}{lcclrl}
\hline \multicolumn{3}{c}{ Italy } & Sample & \multicolumn{3}{c}{ Italy } & Sample \\
\hline \multicolumn{3}{c}{ Age Class } & \multicolumn{3}{c}{ Gender } \\
$18-25$ & $10 \%$ & $37 \%$ & Male & $49 \%$ & $37 \%$ \\
$26-35$ & $15 \%$ & $21 \%$ & Female & $51 \%$ & $63 \%$ \\
$36-45$ & $19 \%$ & $12 \%$ & Occupational Status \\
$46-55$ & $18 \%$ & $14 \%$ & Employed & $57 \%$ & $49 \%$ \\
$56-65$ & $15 \%$ & $17 \%$ & Retired/Inactive & $31 \%$ & $19 \%$ \\
$65+$ & $25 \%$ & $7 \%$ & Students & $12 \%$ & $33 \%$ \\
\hline
\end{tabular}

Table 1: Sample Demographics

\subsection{Recruitment}

Potential volunteers were invited to register for the experiment through a web-form, by email or by phone. Registered individuals were then randomly assigned to one of the sessions of the experiments conducted in their hometown. In order to reach potential participants, 1000 letters were sent to random families selected from the lists of residents in the municipalities involved. Moreover, written advertisements (flyers and posters) were posted in a large number of restaurants, bars, and shops. Further general diffusion was obtained with ads through the municipalities newsletters and a Facebook page. Finally, thanks to the administrative offices of the University, we had the opportunity to send 


\begin{tabular}{ccc}
\hline & Inside earthquake & Outside earthquake \\
\hline Marche & 28 & 48 \\
\hline $\mathrm{N}=76$ & $\begin{array}{c}\text { Fiastra (12) } \\
\text { Tolentino (16) }\end{array}$ & $\begin{array}{c}\text { Petritoli (36) } \\
\text { Macerata(12) }\end{array}$ \\
\hline Emilia & 80 & 96 \\
\hline $\mathrm{N}=176$ & Mirandola (80) & $\begin{array}{c}\text { Vignola (32) } \\
\text { Reggio Emilia (64) }\end{array}$ \\
\hline
\end{tabular}

Table 2: Sessions

emails to about 4000 ex-students from all faculties of the University of Modena and Reggio Emilia (graduated from 2009 to 2015), inviting them to spread the researchers contacts and information about the experiment to their relatives and friends who could qualify to participate. The objective of this procedure was to obtain the highest possible level of diversity of the subjects included, keeping a rigid selection concerning the birth and residence of each subject to the location selected. The sample is not a representative one because we did not stratify the participants according to the criteria. Ours can be considered as a sample of the general population as we included participants according to specific features and aimed at generating the highest possible variance with respect to gender, age class and occupational status within the boundaries that are required to generate the comparative sample needed to test the effect of the earthquake. We set a time frame beyond which we decided to interrupt recruitment and sessions (Details on the dates of the sessions are reported in Table S3 of SOM.) The pool of candidates registered for the experiments were selected for sessions imposing two restrictions. First, the candidate had to be 18 years or older at the time of the experiment (this restriction was required for legal reasons). Second, only residents of either the municipalities in which the session was run, or of the neighbouring ones, could participate in an experiment run there (locations of the sessions, dates, times are reported in Table S19). A final requirement was imposed by the Italian law, i.e. participants should not have criminal charges.

Procedures. Participants were informed that they were allowed to leave at any moment and obtain the show up fee, but nobody left any session. Participants were made aware of the fact that oral communication was forbidden during the experimental sessions. Moreover, mobile cubicles were used to make visual contact among participants impossible.

All instructions were read aloud by an experimenter, the same person for all the sessions. The instructions could be consulted during the experiment, thanks to a specific button present in the software which would re-open the instructions page at any time during the study. The experiment was conducted with the use of a mobile laboratory for experimental economics, using the Reggio Emilia Behavioural Economics Laboratory (REBEL). ${ }^{2}$.

The experimental software was developed in Python using the o-Tree platform Chen et al. (2016): experiments were run on tablets with touch screens and a web-based graphical user interface. These tools were specifically conceived to make the study more accessible to the general population by reducing issues related to the potential lack of computer

\footnotetext{
${ }^{2}$ Details on the events with pictures are available on the web site of the lab : www.rebel.unimore.it,
} 
proficiency. A small exercise to practice with the use of the tablet was requested to the participants before the beginning of the sessions.

Average session time was one hour, and payoffs were expressed in experimental points (tokens), with each token corresponding to 4 euro cents. Subjects received a 5 Euros show up fee and on average extra 15 Euros for the decisions made in the experiment. Payments were made privately and in cash at the end of each session.

We used comprehension questions but we did not exclude subjects who gave wrong responses. In case of incorrect answers, the participants were informed by the software of the incorrect answer and given an explanation of the mistake, in order to help them to fully understand the game. This procedure was intended to overcome potential issues of understanding due to the variance of education levels and age of participants.

The number of participants for each session was planned to be 16. In few cases, due to last minute dropouts, we run sessions of 12 subjects. All sessions were run on Saturdays in order to favour a wider and more diverse participation.

The experiment was conducted in accordance with regulations and relevant guidelines for experiments with human subjects of the REBEL (Reggio Emilia Behavioural Economics Laboratory) at the University of Modena and Reggio Emilia and therefore approved by the REBEL ethics committee. All participants signed a privacy consent form and an information flyer in which allowed they were informed about the anonymized use of the data and the general procedures of the study.

\subsection{Measures}

The experiment consisted of a sequence of tasks, including games and a survey. In the current paper we present only the choices related to the first round of Public Good Game (PGG from now on) and the Distribution Game (DisG from now on $)^{3}$. The survey was presented at the end of the experiment. In each stage of the experiment, subjects were asked to answer 3-4 control questions and they were informed they would not affect their final earnings. In order to prevent between-game learning, no feedback was given between games before the end of the entire experiment. ${ }^{4}$

\subsubsection{Public Goods Game - $P G G$}

Our PGG is a discrete form of Public Goods Game: all group members receive an endowment of $e=40$ experimental points and must decide simultaneously how much of their endowment to invest in a common project, choosing a contribution level among the following possible values, $\left(c_{i} \in 0,10,20,30,40\right)$, knowing that the residual $\left(e-c_{i}\right)$ would remain in their private account. Every point invested in the group account is then doubled and shared equally among group members and individual earnings are determined as follows:

$$
\pi_{i}=e-c_{i}+\alpha \sum_{j=0}^{N} c_{j},
$$

where $\alpha$ is the marginal per capita return (MPCR) of the public good. Free-riding is the dominant strategy for rational self-interested individuals, when MPCR is above $1 / \mathrm{N}$ and below 1 . Social welfare is instead maximised when everyone contributes the whole endowment. The discrete contributions framework, based on Rand and Nowak (2011), is chosen with the aim to facilitate calculations and understanding of the decision structure.

\footnotetext{
${ }^{3}$ The instructions for all tasks are reported in the supplementary material, and results concerning tasks not studied here are reported in Pancotto and Righi (2021)

${ }^{4}$ Further technical details concerning the general design are reported in Supplementary Material.
} 
Table 3: Parameters of the Distribution Game

\begin{tabular}{|c|c|c|c|}
\hline Player & Choice A & Choice B & Choice C \\
\hline Person 1 & 51 & 45 & 42 \\
\hline DICTATOR & 30 & 27 & 24 \\
\hline Person 3 & 9 & 15 & 18 \\
\hline Person 4 & 6 & 9 & 12 \\
\hline Total Income & 96 & 96 & 96 \\
\hline \multicolumn{4}{|l|}{ Criteria } \\
\hline Population Variance & 328.5 & 189 & 126 \\
\hline Bolton-Ockenfels (ERC) & -6.25 & -3.13 & 0 \\
\hline F\&S Strict & -22 & -16 & -12 \\
\hline Minimax & 6 & 9 & 12 \\
\hline Average Person 1-3-4 & 22 & 23 & 24 \\
\hline \multicolumn{4}{|c|}{$\begin{array}{l}\text { Notes: Population Variance is the variance of the pay- } \\
\text { offs of each choice. Bolton \& Ockenfels(ERC) is calculated } \\
\text { as } E R C=-a b s\left(\frac{\text { DictatorPayoff }}{96}-\frac{1}{4}\right) . \quad F \& S \text { Strict }= \\
-\frac{1}{4} \sum a b s\left(\text { Payoff } f_{i}-\text { DictatorPayoff }\right) \text {. Minimax is the value } \\
\text { of the minimum payoff among the four components of the group } \\
\text { in each presented possible choice. Average is the simple average } \\
\text { of the payoffs of the group in each choice excluding the dictator. }\end{array}$} \\
\hline
\end{tabular}

\subsubsection{Distribution Game}

The second experimental task is a distribution game (DisG) Engelmann and Strobel (2004), in which each participant must select one out of three different allocations of the same amount of experimental points to anonymous members of their group. The game can be regarded as a modified dictator game because, after all choices are made, the computer will randomly select only one participant per group whose choice will be used to determine the actual payoffs for every participant in the game. Participants are informed of the structure of the game and aware of the fact that only one of them, selected randomly, will determine with his choices the distribution of resources in the group. This strategy allows to treat the choices made by each participant as salient, given that they should play as if they were selected as dictators. The choices are presented as an option between three cake graphs, each of which has the same size with a different distribution of payoffs.

We propose alternative allocations of the same income (total income always equals 96) among four participants in order to eliminate any potential confound related to efficiency motivations (which would involve options including higher total income, identified in the literature as highly salient (Engelmann and Strobel, 2004)). Parameter values are reported in Table 3 while choice screens presented to subjects are shown in Fig. 2. Parameter values are chosen in order to stress the opposition between a selfish and a pro social choice, keeping total income constant. The pro social choice (Choice C in Table 3) is selected according to F\&S (see Fehr and Schmidt 1999), ERC (see Bolton and Ockenfels 2000) and the Minimax criterium, against the selfish one (Choice A) as codified in Engelmann and Strobel (2004). Participants were not informed of the outcome of the PGG before playing the DisG. 


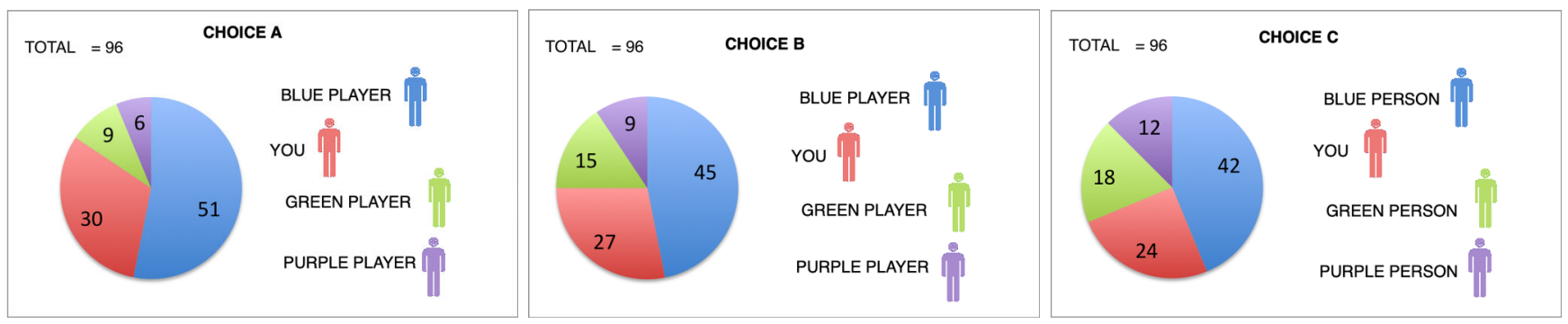

Figure 2: Choices in the DisG as translated in English from the Italian original figure. The size of the pie chart is the same for the three choices because total income is constant and equal to 96 . In the chart, the color of the share corresponds to the color of the person: for example BLUE PERSON takes the blue share of the pie.

\subsubsection{Survey}

The full list of survey questions (translated from the original Italian survey) are reported in the Supplementary Material. Survey questions in our design were especially important because they allowed us to complement the behavioral measures with self-reported measures of civic capital, trust and information about their own experience of the earthquake. We asked participants to answer a set of different questions about:

- Personal information: citizenship, age, gender, composition of the household, proxies of income, number of siblings, work status.

- Embeddedness: All the participants were resident in the village, town or city selected in the design, at the time of the experiment. Nonetheless, we also wanted to capture how rooted each participant and their families were in the region, given the importance of embeddedness and persistence for civic capital. Therefore we chose to ask first about where the participant attended primary school, because we considered it to be a reliable indicator of the fact that primary socialization happened within that community or elsewhere. Secondly, we asked about the parents' birthplace as a proxy of family roots (birthplace of mother and father). Finally, we asked whether the participant attended primary school inside or outside the region or county of residence. We created an indicator of embeddedness which summarizes these four responses. The embeddedness index ranges between 4 - when the participant is born in the region, has gone to primary school in the region and his mother and father are born in the region as well - and 0 if neither she/he nor the parents were born in the region, and she/he did not go to elementary school there. This indicator generates a discrete variable that measures approximately the degree of embeddedness of the participant. The variable used in the analysis is embeddeddness. Summary statistics about this variable are reported in SOM (Table S4 in Supplementary Material).

- Damage: In the survey we asked our participants a set of questions related to their personal experience with the earthquake and the direct effect it had on their material conditions. These questions are useful to get insights about the actual material losses the participants experienced, and the consequences on their living arrangements. We asked participants about the amount of damage suffered by their houses, i.e., the habitability of their house at the time of the experiment in order to have a better overview of the situation at the time of the data collection (which was performed three years after the earthquake in Emilia and one year after the event in Marche). If the house was still inhabitable and though the Italian government offered alternative housing solutions in the proximity of the place of residence, serious damage usually resulted in displacement and relocation which is important for the individual perception of damage but also for the disruption of social ties that emerge with 
displacement. The variable used in the analysis is damage.

- Trust We used a sub-sample of questions from the World Value Survey to measure the participants' level of generalized trust (WVS, 2020).

- Civic capital - CK: Building upon the work of Guiso et al. (2004) and Cartocci (2007), we measured civic capital by means of the answer to three different questions, each one related to a different form of solidarity. The three questions were about blood donation in the previous year, voting in the previous European elections (2014) and in the most recent European referendum (we did not specify which one to avoid potential confound related to the political content of the referendum itself). We created a synthetic indicator of civic capital that takes value from 0 to 3 . We use this indicator instead of the single survey answers in an attempt to overcome the problem of missing values related to potential inability to engage in one of the chosen behaviors (such for instance health issues making blood donation unsafe or impossible, or being underage at the time of the elections and referendum). ${ }^{5}$ The variable used in the analysis is $C K$.

\section{Analysis of aggregate data}

As a first step, we report mean values of PGG and DisG (Table 4). As we compare average values of discrete values (which do not easily allow to compare mean distributions) and as the size of the two samples were different, we compare frequencies of contribution inside the seismic area (ISA) as compared to outside (OSA), with the latter taken as a reference. We test whether the difference is significant with respect to the reference (Cohen, 1988) using a chi-square goodness of fit test.

We find that the average contribution $(\mathrm{PGG})$ from people living inside the seismic area (mean PGG ISA $=25.55$ ) is significantly higher than the contribution of those who live outside of it (mean PGG OSA $=25.34$ ), with a chi-square significant at $95 \%(\mathrm{X}$-squared $=11.746, \mathrm{df}=4, \mathrm{p}$-value $=0.01935) .{ }^{6}$

RESUlT 1. Average contribution in the PGG is higher among participants living in the areas affected by the earthquake (inside seismic area), in accordance with H1a.

We replicate the same analysis for the DisG, separating the choices of participants living inside and outside the seismic area. We codify selfish choices as 1 , intermediate as 2 and fair choices as 3 , and calculate an average indicator of fairness per each sub sample: a higher value would correspond to fairer choices on average. For participants inside the seismic area (ISA), the average value of this indicator is 2.425926, while for participants outside is 2.291667. In order to compare the two values, we again implement a chi-square test of frequencies comparison. The difference is significant according to the chi-square test only at $90 \%(\mathrm{X}$-squared $=5.293, \mathrm{df}=2, \mathrm{p}$-value $=0.0709$.

RESULT 2. The frequency of fair allocations in the DisG is higher among participants living in the areas affected by the earthquake, in accordance with H2a.

\footnotetext{
${ }^{5}$ To treat these variables we use the following codification for example to blood donation: 1 , the person has donated blood, 0 the person has not donated blood, NA, the participant could not donate for other reasons.

${ }^{6}$ The power of the chi-square test of association between frequencies here represented, is $98 \%(\mathrm{w}=0.3297838, \mathrm{~N}=252, \mathrm{df}=4$, sig.level $=0.05$ ).
} 
Table 4: Comparison ISA (inside sismic crater) vs OSA (outside sismic crater) and damaged vs no damage

\begin{tabular}{lcccc}
\hline \multicolumn{7}{l}{ ISA vs OSA } \\
\hline task & ISA & $\mathrm{X}, \mathrm{p}$-value & OSA & $\mathrm{df}$ \\
\hline PGG & 25.55 & $11.746, \mathrm{p}=0.019$ & 25.34 & $\mathrm{df}=4$ \\
DisG & 2.42 & $5.29, \mathrm{p}=0.07$ & 2.29 & $\mathrm{df}=2$ \\
\hline Damage & vs no damage & & \\
\hline task & damage & $\mathrm{X}, \mathrm{p}$-value & no-damage & $\mathrm{df}$ \\
\hline PGG & 31.05 & $8.738, \mathrm{p}=0.06799$ & 24.91 & $\mathrm{df}=4$ \\
DisG & 2.68 & $4.78, \mathrm{p}=0.09$ & 2.31 & $\mathrm{df}=2$ \\
\hline
\end{tabular}

Table 5: ISA vs OSA unpacked by region

\begin{tabular}{lll}
\hline \multicolumn{3}{c}{ PGG } \\
\hline Marche & Emilia \\
ISA & $26(9.73)$ & $24.05(12.09)$ \\
vs. & p-val=0.0002 & p-val=0.03 \\
OSA & $23.8(10.92)$ & $27.42(12.00)$ \\
\hline & & DisG \\
\hline & Marche & Emilia \\
ISA & $2.4(0.73)$ & $2.4(0.81)$ \\
vs. & p-val=0.0012 & p-val=0.34 \\
OSA & $2(0.84)$ & $2.3(0.84)$ \\
\hline
\end{tabular}

Given the structure of our sample and the procedure implemented to collect data, which involves two regions affected by disasters similar in nature but different in effects and timing, we also explored the variations at the regional level. The top half of Table 5 shows that in Marche PGG values are significantly higher for ISA participants, as compared to OSA (26 vs 23.8, p-value: 0.0002). The opposite is true for Emilia-Romagna (ISA $=24.05$ vs OSA = 27.42, p-val: 0.03), where people who were not affected by the earthquake were more generous in the PGG. Concerning DisG, Table 5 shows that in Marche ISA values are significantly higher than for OSA participants, while in Emilia no significant difference emerges in the measures for the two subgroups. We also tested whether the amount of damage suffered is related to the preference for redistribution and we found that the damage suffered, which was significantly higher for inhabitants of Marche, affects the preference for redistribution.

In Table 6 we further decompose the results by looking at contribution levels of the seven municipalities.

Looking at city level, cities affected by the earthquake in Marche contribute more on average than the others; the difference being even bigger for the DisG (Fiastra 2.58, and Tolentino 2.56 are the locations with the highest percentage of fair allocations). The opposite is true for Emilia when it comes to PGG, where Vignola, outside of the seismic area, presents the highest average contribution (27.5) followed by Mirandola. No apparent pattern emerges according to 
Table 6: Aggregate data summary

\begin{tabular}{|c|c|c|c|c|c|c|}
\hline Region & Crater & City & $\begin{array}{l}\text { PGG } \\
\text { mean(sd) }\end{array}$ & $\begin{array}{l}\text { DisG } \\
\text { mean(sd) }\end{array}$ & $\begin{array}{l}\text { CK index } \\
\text { mean }(\mathrm{sd})\end{array}$ & $\begin{array}{l}\text { Embed. } \\
\text { mean(sd) }\end{array}$ \\
\hline & YES & Fiastra & $26.7(8.88)$ & $2.58(0.66)$ & $1.42(0.9)$ & $0.38(0.90)$ \\
\hline & YES & Tolentino & $26.9(8.73)$ & $2.56(0.72)$ & $1.75(1.06)$ & $0.08(1.06)$ \\
\hline & $\mathrm{NO}$ & Petritoli & $24.7(11.8)$ & $2.08(0.80)$ & $1.78(0.54)$ & $0.4(0.54)$ \\
\hline & $\mathrm{NO}$ & Macerata & $25(6.74)$ & $2.42(0.66)$ & $1.5(0.79)$ & $0.44(0.79)$ \\
\hline \multirow[t]{2}{*}{ Marche } & & & $25.52(9.99)$ & $2.32(0.77)$ & $1.67(0.77)$ & $0.34(0.54)$ \\
\hline & vs & X-sq $\rightarrow$ & $11.922(0.01794)$ & $7.3365(0.025)$ & $8.69(0.03)$ & $185(2.2 \mathrm{e}-16)$ \\
\hline \multirow[t]{4}{*}{ Emilia Romagna } & & & $25.39(12.1)$ & $2.36(0.82)$ & $1.60(0.91)$ & $0.96(0.50)$ \\
\hline & YES & Mirandola & $25.1(11.6)$ & $2.38(0.83)$ & $1.74(0.92)$ & $1(0.92)$ \\
\hline & NO & ReggioEmilia & $24.7(12.1)$ & $2.44(0.79)$ & $1.39(0.97)$ & $0.8(0.97)$ \\
\hline & NO & Vignola & $27.5(13.7)$ & $2.19(0.85)$ & $1.66(0.7)$ & $1.19(0.7)$ \\
\hline
\end{tabular}

the ISA versus OSA dimension here, when unpacked by region. For DisG, figures are reversed: the fairest location in Emilia is Reggio Emilia, while the least fair is Vignola.

To control if the results presented may be ascribed to pre-existing conditions or confounding factors, we report aggregate values of CK index and Embeddedness in the same Table (last columns). Here we see that, in general, civic capital is higher in Marche than in Emilia, but the pattern is not associated with the ISA variable. This allows us to rule out the possibility that our results can be ascribed to preexisting differences in terms of civic capital. On the contrary, for Emilia, the highest civic capital is in Mirandola, consistently with the results of the DisG. Finally, embeddedness should capture how homogeneous the community is in terms of participants origins: here we do not see patterns associated with the disaster, although we definitely captured a more embedded sample in Emilia with respect to Marche (Significant difference 0.96 versus 0.34, X.sq 185, p-val: 2.2e-16).

RESULT 3. In Marche people living inside the seismic area contribute more and have a stronger preference for fairness, while in Emilia we observe significantly higher contributions outside it.

This result requires to control for alternative explanations. Since the timing of the experiment with regard to the earthquake is different between the two locations, we cannot exclude that this played a role. However, we decide to look into heterogeneity between individuals in order to identify possible explanations of the observed differences.

\section{Analysis of individual data}

\subsection{Contributions to the $P G G$}

In order to study the determinants of contributions, we first run a linear regression on the PGG variable. Regressors included are selected according to the theoretical background of the study, while taking into account a preliminary analysis of cross correlations, reported in Supplementary Material (Table S5). We study the following linear regression 
model: ${ }^{7}$

$$
P G G=\beta_{1} D i s G+\beta_{1} c k+\beta_{3} I S A+\beta_{4} \text { Damage }+ \text { controls }
$$

The first explanatory variable for contribution levels in the PGG is the choice in the DisG, the variable indicating the preference for a fairer distribution of income. The second explanatory variable refers to civic capital $(c k)$, which should capture the strength of the relationship between civic capital and cooperation in the PGG. Further, we check whether the effect of the disaster has changed the behavior in our two samples by introducing a dummy earthquake, that takes value 1 when the participants declared to be present and resident in the seismic area at the time of the event. To capture the actual degree of damage suffered by the households, we use the current habitability variable, which indicates whether the house of the family is currently habitable or not (damage indicator). We also includes group level controls - a dummy Region - and individual level controls such as age, employment condition and the embeddedness indicator, which include both demographics and indicators more specifically related to the event.

In Table 7 we see the results of this regression. The coefficient of the variable civic capital (CK) is strongly significant in almost all models (1 to 10): people that declare to engage everyday in cooperative activities contribute more to the PGG. The second evidence is that participants with a preferences for fairer distributions contribute more. The latter result is robust to all specifications. Our control variable related to the presence inside the seismic area of the participant (SA) is not significant. Also, there is no substantial significance for the regional dummy.

The degree of damage suffered by the subject's main home (variale current_habitability), is an important control variable because it is a direct measure of losses suffered by individuals because of the disaster. This variable is included in Model 6 to 10 where instead ISA is excluded, given that these variables are strongly correlated $(\mathrm{t}=-3.3849$, $\mathrm{df}=$ 245 , $\mathrm{p}$-value $=0.0008291)$. If we substitute the current_habitability variable to the ISA variable, we find a negative effect on contributions in the PGG. This means that people which did not suffer a damage (their homes are habitable) are on average contributing less, whereas people with damaged houses contribute more (as predicted by Hp2a). The fact that here the ISA variable is not significant - as instead emerged in the aggregate analysis - is not contradictory, but it is qualified by the presence of the habitability indicator that offers a more specific measure of the real impact of the earthquake as the amount of damage suffered.

RESULT 4. Higher contribution to the $P G G$ is a result of the material damage suffered in the earthquake, while controlling for civic capital and fairness, both positively correlated with cooperation.

Further controls include age, which is positive and significant, suggesting that older people are more cooperative (Gutiérrez-Roig et al., 2014), but given that age is also strongly correlated with social capital indicator (cor $=0.39, \mathrm{t}$ $=6.5758, \mathrm{df}=241, \mathrm{p}$-value $=2.976 \mathrm{e}-10)$, we postpone the analysis of the indicators of social capital in a specific regression (indeed in Model 9 the introduction of age renders ck indicator non significant). Current habitability is also positively correlated with age, suggesting that older people have been affected more by the event $(\mathrm{t}=-3.049$, $\mathrm{df}=$ 238 , p-value $=0.002555)$.

Given that our research question relates to assumed difference between the two regions, for robustness we use a cross-section multilevel analysis, in which we use interaction term models that capture subgroups of participants

\footnotetext{
${ }^{7}$ The results of an ordered logit estimation of the same models is provided in the Supplementary Material.
} 
Table 7: Determinants of contribution in the PGG

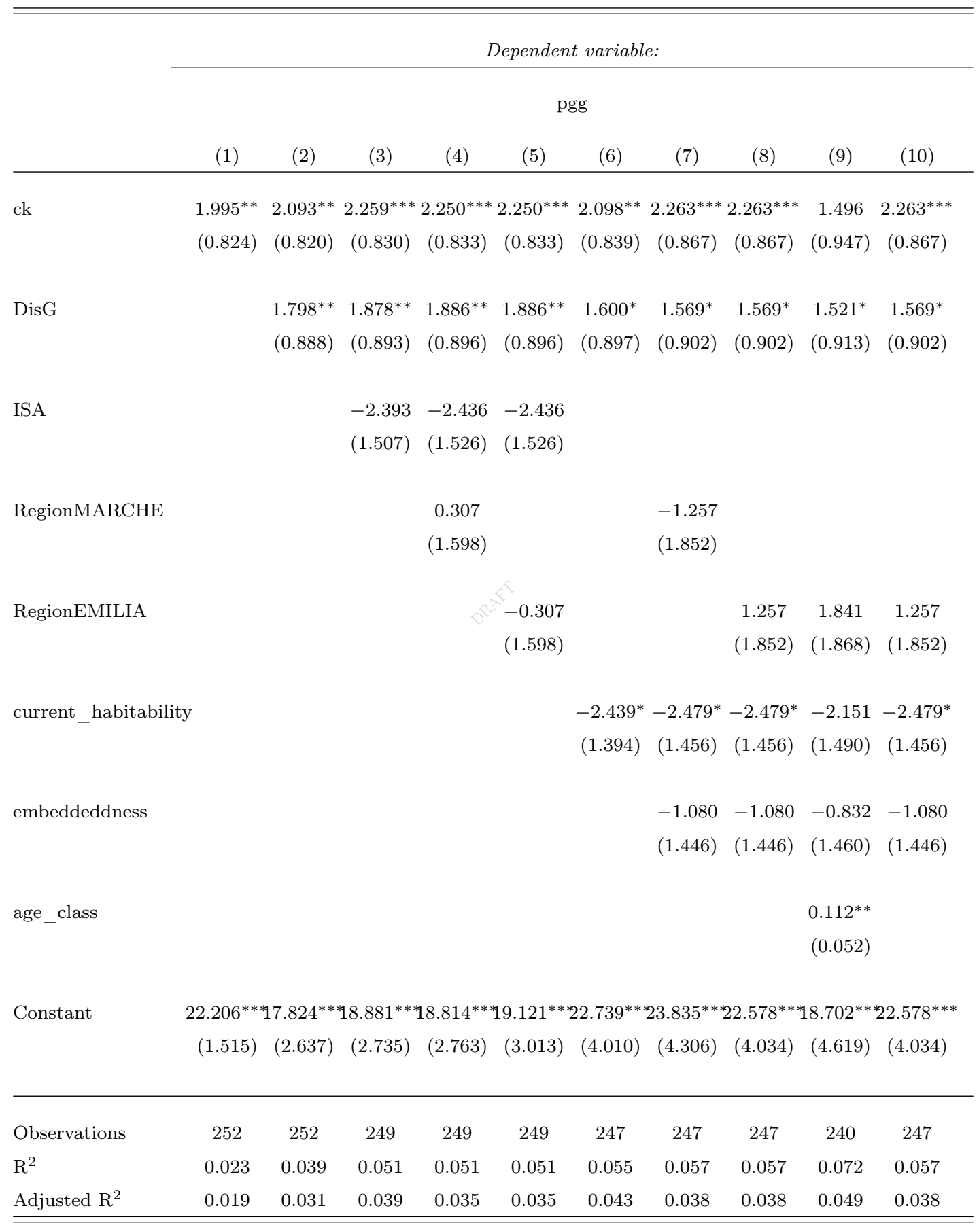

Note:

${ }^{*} \mathrm{p}<0.1 ;{ }^{* *} \mathrm{p}<0.05 ;{ }^{* * *} \mathrm{p}<0.01$ 
created with these variables. Given that these results do not report significant differences between the regions, we can conclude that our result is robust to this control $^{8}$

${ }^{8}$ A Bayesian factor approach suggests a mild relevance of a factor indicating higher contribution. Results are in Supplementary Material. 


\subsection{Preference for redistribution (DisG)}

Our first result indicates that higher contributions of people who directly suffered damages from the earthquake are strongly associated with being fair in the DisG and have high civic capital. To explore this result, here we analyze the individual determinants of fairness preferences. We use as explanatory variable the following: age, current house habitability, civic capital indicator, earthquake dummy, region dummy and embeddedness indicator. The estimated linear equation is:

$$
D i s G=\beta_{1} C K+\beta_{2} I S A+\beta_{3} \text { damage }+ \text { controls. }
$$

The results from different models with different combinations of these variables are reported in Table 8. The first result that stands out is that our CK indicator does not explain choices in the DisG, differently from what happens with the PGG. On the contrary, two results are consistent with what found in the PGG regression: first we find that current_habitability of the house (damage) is negatively related to fairness which suggests again that those who suffered direct damage from the disaster prefer fairer choices. Also, ISA, which identifies individuals residing in the seismic area, is not significant in the DisG regression, which is coherent with the idea that what matters at the individual level is the individual damage suffered. Given that current_habitability is correlated with residence in the seismic area $(\mathrm{t}=-3.3849, \mathrm{df}=245, \mathrm{p}$-value $=0.0008291)$ with age $(\mathrm{t}=-3.049, \mathrm{df}=238, \mathrm{p}$-value $=0.002555)$ and with Region $(\mathrm{t}=-4.2035, \mathrm{df}=245, \mathrm{p}$-value $=3.685 \mathrm{e}-05)$, in Model $(7)$ we test a model without these controls to test for potential variance inflation and verify that the indicator of current habitability is robustly significant also without these controls. This evidence suggests the following result:

RESUlT 5. Actual damages suffered because of the disaster (house in-habitability) predicts preference for fairness: people who suffered more damage have a stronger preference for a fairer distribution of resources. 
Table 8: Determinants of fairness in the DisG

\begin{tabular}{|c|c|c|c|c|c|c|c|}
\hline & \multicolumn{7}{|c|}{ Dependent variable: } \\
\hline & \multirow[b]{2}{*}{$(1)$} & \multirow[b]{2}{*}{$(2)$} & \multicolumn{3}{|c|}{ dictator_choice } & \multirow[b]{2}{*}{ (6) } & \multirow[b]{2}{*}{$(7)$} \\
\hline & & & (3) & (4) & $(5)$ & & \\
\hline \multirow[t]{2}{*}{ CK } & -0.055 & -0.046 & -0.062 & -0.060 & -0.015 & -0.011 & -0.068 \\
\hline & $(0.058)$ & $(0.059)$ & $(0.060)$ & $(0.060)$ & $(0.065)$ & $(0.068)$ & $(0.061)$ \\
\hline \multirow[t]{2}{*}{ ISA } & & 0.167 & 0.118 & 0.131 & 0.123 & 0.121 & \\
\hline & & $(0.107)$ & $(0.110)$ & $(0.110)$ & $(0.112)$ & $(0.112)$ & \\
\hline \multirow[t]{2}{*}{ current_habitability } & & & $-0.185^{*}$ & $-0.216^{* *}$ & $-0.231^{* *}$ & $-0.230^{* *}$ & $-0.217^{* *}$ \\
\hline & & & $(0.101)$ & $(0.104)$ & $(0.107)$ & $(0.107)$ & $(0.101)$ \\
\hline \multirow[t]{2}{*}{ RegionMarche } & & & & -0.151 & -0.111 & -0.122 & \\
\hline & & & & $(0.117)$ & $(0.120)$ & $(0.134)$ & \\
\hline \multirow[t]{2}{*}{ age } & & & & & $-0.006^{*}$ & $-0.006^{*}$ & \\
\hline & & & & & $(0.004)$ & $(0.004)$ & \\
\hline \multirow[t]{2}{*}{ embeddeddness } & & & & & & -0.019 & 0.040 \\
\hline & & & & & & $(0.105)$ & $(0.092)$ \\
\hline \multirow[t]{2}{*}{ Constant } & $2.438^{* * *}$ & $2.313^{* * *}$ & $2.711^{* * *}$ & $2.801^{* * *}$ & $2.977^{* * *}$ & $2.991^{* * *}$ & $2.824^{* * *}$ \\
\hline & $(0.107)$ & $(0.128)$ & $(0.248)$ & $(0.257)$ & $(0.287)$ & $(0.297)$ & $(0.222)$ \\
\hline Observations & 252 & 249 & 247 & 247 & 240 & 240 & 247 \\
\hline $\mathrm{R}^{2}$ & 0.004 & 0.012 & 0.025 & 0.032 & 0.043 & 0.043 & 0.021 \\
\hline Adjusted $\mathrm{R}^{2}$ & -0.0005 & 0.004 & 0.013 & 0.016 & 0.023 & 0.019 & 0.009 \\
\hline
\end{tabular}




\subsection{Civic Capital}

We study factors affecting civic capital with the following linear regression:

$$
C K=\beta_{1} \text { Dis } G+\beta_{1} \text { trust } W V S+\beta_{4} \text { embeddedness }+\beta_{5} \text { damage }+\beta_{6} I S A+\text { controls }
$$

where trust WVS stands for and indicator created with answers to World Value Survey trust questions, and the embeddeddness indicator. The results with different combinations of the regressions are reported in Table 9.

The striking result that we first observe is that there is no relationship between responses in the DisG and civic capital, in all specifications presented. Preference for fairness - elicited in the lab - is not related to civic behaviors outside the lab. This evidence is important because it suggests a qualification to previous results: while choices in PGG are affected by civic capital, choices in the DisG are not.

In turn, the dummy ISA is again not significant in any model proposed, such as we found in the previous two regressions; also the variable current_habitability is significant only if included alone, while its significance disappears as soon as we include other explanatory variables, namely responses to questions concerning trust and honesty from WVS (2020) (trust WVS: people_honest, people_trustable variables).

When we introduce the embeddedness indicator, which stands for a sign of how the individuals are rooted in the community in terms of their family presence and history in the area, we see that it does play a major role: highly embedded individuals show more civic behaviors. In Model (6) we see that current_habitability is significant, but this effect can be ascribed to the strong correlation between variables embeddedness and current habitability $(\mathrm{t}=2.9161$, $\mathrm{df}=245, \mathrm{p}$-value $=0.003872)$

To summarize, we find that civic capital appears to be more related to structural features of the population than to individual characteristics.

RESULT 6. Civic capital is not affected by the amount of damages caused by the earthquake, but it is a long-term feature of communities, founded on the long term persistence of cultural and social norms.

We represent a summary of the results of the regressions in the Figure 3: concerning main variables and at individual level, we found that preference for fairness (DisG) and contributions in the PGG are correlated, as well as CK behaviors are associated with higher contributions in the PGG: both behaviors lead to higher contributions, but are driven by different factors. CK is associated with the embeddeddness of the family in the community while preference for redistribution is connected with the actual damage suffered because of the event. These two elements are therefore both influencing the decision to cooperate, but from different roots, fact that is confirmed by the lack of association between them.

\section{Discussion and conclusions}

Collective action problems are inevitable in communities hit by disasters in which inhabitants need to decide whether to invest time, effort or money in helping each other and in rebuilding, or to free ride while still enjoying the benefits produced by the rest of the group. Evidence from across the world shows that neighborhoods and communities

with more civic capital made efficient and effective post-disaster recoveries because of their ability to coordinate and cooperate (Patterson et al., 2010; Weil et al., 2018). We conducted lab-in-the-field experiments with the aim of testing 
Table 9: Correlations with social capital

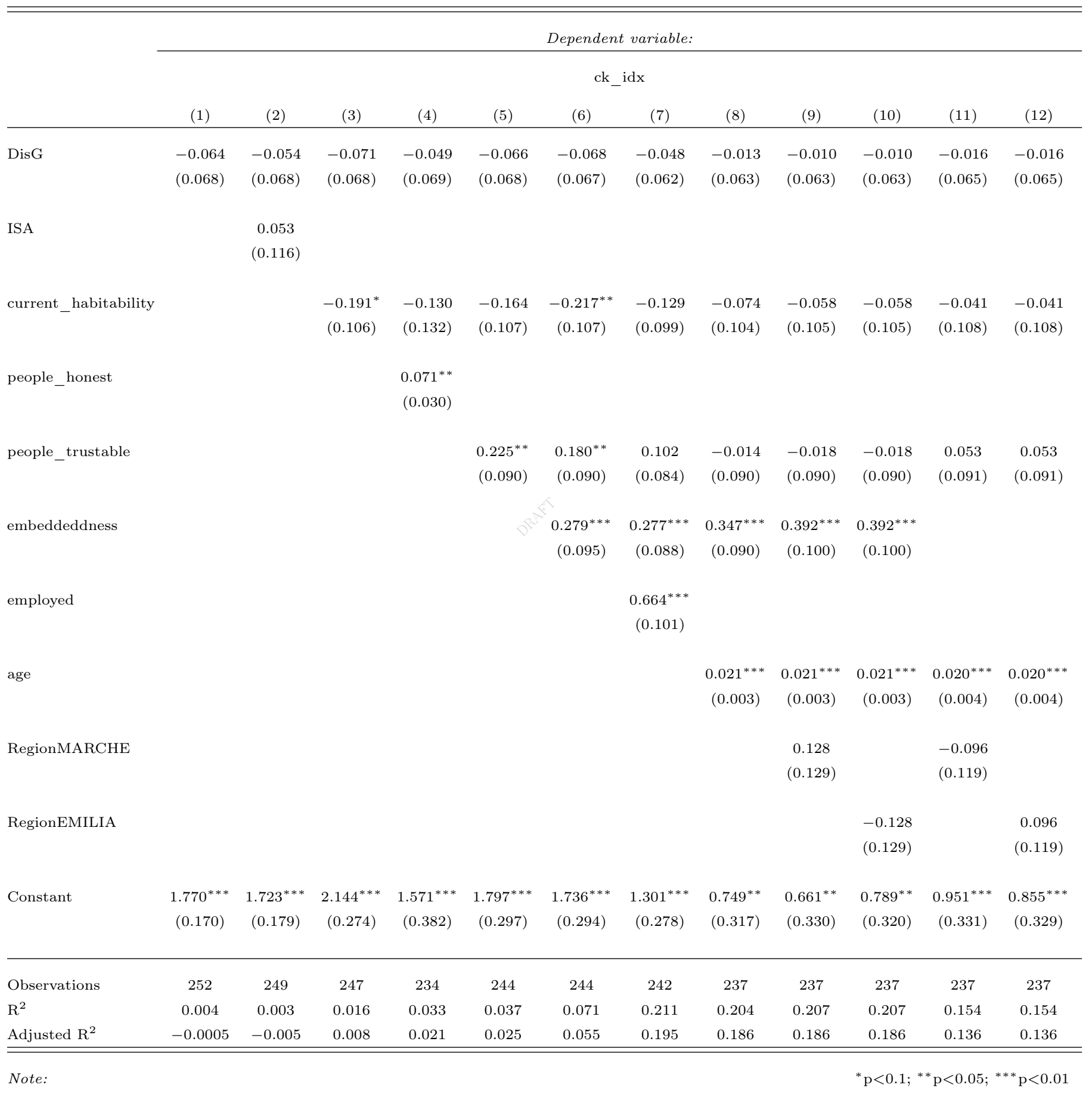




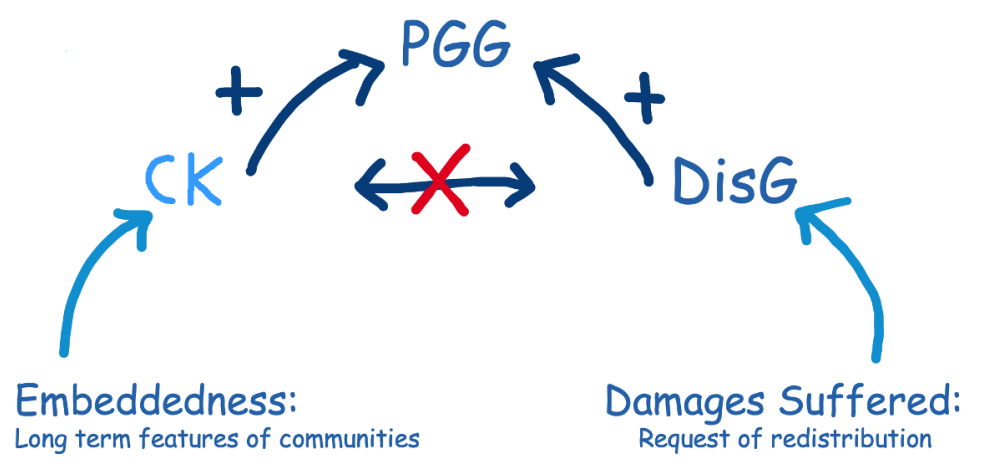

Figure 3: Relationships among variable

the effects of earthquakes on cooperation and fairness in two neighboring Italian regions. In our experiment, residents within the seismic areas were more cooperative than their fellow citizens living in the same regions but outside the earthquake areas, in both Emilia and Marche. Civic capital was not affected by the disaster, in neither of the two regions, as predicted by Guiso et al. (2011) in his treatment of civic capital as being a persistent trait of communities.

Participants affected by earthquakes in Marche were more cooperative than participants from Emilia, with the former showing a preference for contributing the fair split in the DisG. This preference is explained by the damage suffered, but it is also in line with the finding by Baldassarri (2020) that reports the results of a large-scale, nationwide lost-letter experiment run in Italy. In Marche, 54 per cent of the letters were returned, showing support for generalized reciprocity hypothesis.

This paper is related to three strands of literature, each one corresponding to a different level of analysis. At the micro-level, this study contributes to the understanding of the multiple individual factors explaining variation in cooperative behavior after catastrophic events. Previous research shows that property damage predicts a general decrease in prosocial allocations (Vardy and Atkinson, 2019), and that previous experience of natural disasters increases risk preparedness and motivation to take preventive measures (Wachinger et al., 2013). Our study shows that age, employment status and the amount of damage suffered strongly correlate with cooperative decisions and preference for fairness. Additionally, we did not find any evidence suggesting that civic capital does correlate with the damage.

At the meso-level, this paper contributes to the literature on within-country variation in civic capital by focusing on the similarities and differences between communities living in North-East and Central Italy. Civic capital has been so far related to economic development Guiso et al. (2011), social distancing during the COVID-19 pandemic (Barrios and Hochberg, 2020), corruption and crime (Buonanno et al., 2009), but not specifically to post-disaster resilience. In communities with higher civic capital, individuals trust their fellow community members and are able to display prosocial behavior that is not directly related to their self-interest. In these communities, citizens are able to provide public goods (Herrmann et al., 2008), but less is known about the relationship between civic capital and external shocks. By measuring civic capital in communities differently affected by similar disasters, we aim to explain its long term consequences and its role in supporting cooperation over time and under difficult circumstances.

Finally, this study contributes to the literature on post disaster resilience. It adds to it by offering a within-country comparison of the effects of earthquakes on a number of locations. By focusing on neighbouring regions belonging 
to a well-defined area hit by the same disaster few years apart we aim to control for unobserved endogeneity, and then to provide more conclusive evidence on the determinants of post-disaster resilience. Barone and Mocetti (2014) compared the short- and long-time effects of two earthquakes that happened in two Italian regions on GDP per capita. In accordance with other studies about the North-South institutional divide in Italy, better pre-quake institutions might be more capable of managing the external shock and the following recovery. Overall, in the long-term, the earthquake seems to worsen regional differences in both economic and social development. The participants in this study come from two adjacent regions that, although different, are expected to be quite similar with respect to civic capital and quality of institutions.

This study shows that resilience is a compound phenomenon that results from the combination of different factors, some of which we were not able to address here. One limitation of this work is that the data collection was performed at different time points after the disaster, and this hidden dimension could lead to some unexplained variance in the results. The time dimension is also relevant because the institutional reaction might have been quicker or slower, therefore affecting the experienced damage and the variables linked to trust. Finally, the differences in the external shocks, i.e., the earthquakes, and their immediate effects could have played a role that our work was not able to capture. The earthquakes that hit Emilia in 2012 caused damage estimated at around 12 billion Euros and causing 27 victims, whereas the earthquakes in Central Italy, including Marche, which caused a total damage estimated in 27 billion euros and killed 299 people.

\section{References}

Aldrich, D. P. (2012). Building resilience: Social capital in post-disaster recovery. University of Chicago Press.

Aldrich, D. P. and M. A. Meyer (2015). Social capital and community resilience. American behavioral scientist $59(2)$, 254-269.

Alesina, A. and G.-M. Angeletos (2005). Fairness and redistribution. American economic review $\underline{95}$ (4), 960-980.

Alesina, A. and E. L. Ferrara (2005). Ethnic diversity and economic performance. Journal of economic literature $\underline{43}(3)$, 762-800.

Baldassarri, D. (2020). Market integration accounts for local variation in generalized altruism in a nationwide lost-letter experiment. Proceedings of the National Academy of Sciences 117(6), 2858-2863.

Barone, G. and S. Mocetti (2014). Natural disasters, growth and institutions: a tale of two earthquakes. Journal of $\underline{\text { Urban Economics }}$ 84, 52-66.

Barrios, J. M. and Y. Hochberg (2020). Risk perception through the lens of politics in the time of the covid-19 pandemic. Technical report, National Bureau of Economic Research.

Battiston, P. and S. Gamba (2016). When the two ends meet: An experiment on cooperation across the italian north-south divide. Technical report, LEM Working Paper Series.

Bénabou, R. and J. Tirole (2006). Incentives and prosocial behavior. American economic review 96(5), 1652-1678. 
Bigoni, M., S. Bortolotti, M. Casari, and D. Gambetta (2019). At the root of the north-south cooperation gap in italy: Preferences or beliefs? The Economic Journal 129(619), 1139-1152.

Bigoni, M., S. Bortolotti, M. Casari, D. Gambetta, and F. Pancotto (2016). Amoral familism, social capital, or trust? the behavioural foundations of the italian north-south divide. The Economic Journal 126(594), 1318-1341.

Bolton, G. E. and A. Ockenfels (2000). Erc: A theory of equity, reciprocity, and competition. The American economic review $\underline{90}(1), 166-193$.

Bracco, E., M. De Paola, and C. P. Green (2015). Long lasting differences in civic capital: evidence from a unique immigration event in italy. Journal of Economic Behavior \& Organization $\underline{120}, 160-173$.

Buonanno, P., D. Montolio, and P. Vanin (2009). Does social capital reduce crime? The journal of law and economics $\underline{52}(1), 145-170$.

Cartocci, R. (2007). Mappe del tesoro: atlante del capitale sociale in Italia, Volume 168. Il mulino.

Cassar, A., A. Healy, and C. Von Kessler (2017). Trust, risk, and time preferences after a natural disaster: experimental evidence from thailand. World Development $94,90-105$.

Chen, D. L., M. Schonger, and C. Wickens (2016). otree. an open-source platform for laboratory, online, and field experiments. Journal of Behavioral and Experimental Finance $\underline{9}, 88-97$.

Cohen, J. (1988). Statistical power analysis for the behavioral sciences. Lawrence Erlbaum Associates, Publishers.

Cutter, S. L., L. Barnes, M. Berry, C. Burton, E. Evans, E. Tate, and J. Webb (2008). A place-based model for understanding community resilience to natural disasters. Global environmental change 18(4), 598-606.

duPont, W. and I. Noy (2015). What happened to kobe? a reassessment of the impact of the 1995 earthquake in japan. Economic Development and Cultural Change $\underline{63}(4), 777-812$.

Engelmann, D. and M. Strobel (2004). Inequality aversion, efficiency, and maximin preferences in simple distribution experiments. American Economic Review 94(4), 857-869.

Eränen, L. and K. Liebkind (1993). Coping with disaster. In International handbook of traumatic stress syndromes, pp. 957-964. Springer.

Fehr, E. and U. Fischbacher (2004). Social norms and human cooperation. Trends in cognitive sciences $8(4), 185-190$.

Fehr, E., U. Fischbacher, and S. Gächter (2002). Strong reciprocity, human cooperation, and the enforcement of social norms. Human nature $\underline{13}(1), 1-25$.

Fehr, E. and K. M. Schmidt (1999). A theory of fairness, competition, and cooperation. The Quarterly Journal of Economics $114(3), 817-868$.

Felice, E. (2018). The socio-institutional divide: explaining italy's long-term regional differences. Journal of $\underline{\text { Interdisciplinary History }} \underline{49}(1), 43-70$. 
Felice, E. and G. Vecchi (2015). Italy's growth and decline, 1861-2011. Journal of Interdisciplinary History $\underline{45}(4)$, $507-548$.

Fleming, D. A., A. Chong, and H. D. Bejarano (2014). Trust and reciprocity in the aftermath of natural disasters. The Journal of Development Studies 50(11), 1482-1493.

Grimalda, G., N. Buchan, and M. Brewer (2015). Globalization, social identity, and cooperation: An experimental analysis of their linkages and effects. Technical report, Global Cooperation Research Papers.

Gualtieri, G., M. Nicolini, F. Sabatini, and L. Zamparelli (2018). Natural disasters and demand for redistribution: lessons from an earthquake. Technical report, Working Paper, No. 015.2018, Fondazione Eni Enrico Mattei (FEEM), Milano.

Guiso, L., P. Sapienza, and L. Zingales (2004). The role of social capital in financial development. American economic review $94(3), 526-556$.

Guiso, L., P. Sapienza, and L. Zingales (2011). Civic capital as the missing link. Handbook of social economics $\underline{1}$, $417-480$.

Gutiérrez-Roig, M., C. Gracia-Lázaro, J. Perelló, Y. Moreno, and A. Sánchez (2014). Transition from reciprocal cooperation to persistent behaviour in social dilemmas at the end of adolescence. Nature communications $\underline{5}(1), 1-7$.

Helliwell, J. F. and R. D. Putnam (1995). Economic growth and social capital in italy. Eastern economic journal 21(3), 295-307.

Henrich, J., R. Boyd, S. Bowles, C. Camerer, E. Fehr, H. Gintis, and R. McElreath (2001). In search of homo economicus: behavioral experiments in 15 small-scale societies. American Economic Review 91(2), 73-78.

Henrich, J., S. J. Heine, and A. Norenzayan (2010). The weirdest people in the world? Behavioral and brain sciences $\underline{33}(2-3), 61-83$.

Herrmann, B., C. Thöni, and S. Gächter (2008). Antisocial punishment across societies. Science 319(5868), 1362-1367.

Ichino, A. and G. Maggi (2000). Work environment and individual background: Explaining regional shirking differentials in a large italian firm. The Quarterly Journal of Economics 115(3), 1057-1090.

Imperiale, A. J. and F. Vanclay (2019). Command-and-control, emergency powers, and the failure to observe united nations disaster management principles following the 2009 l'aquila earthquake. International journal of disaster risk $\underline{\text { reduction }} \underline{36}, 101099$.

Jonas, K. J. (2012). Prosocial Behavior in the Context of Crisis, Chapter 4, pp. 57-77. John Wiley \& Sons, Ltd.

Kaniasty, K. and F. H. Norris (1995). In search of altruistic community: Patterns of social support mobilization following hurricane hugo. American journal of community psychology 23(4), 447-477.

Loenhout, J. (2020). Human cost of disasters. an overview of the last 20 years: 2000-2019. Technical report, CRED, UNDRR, Geneva. 
Mayer, D. (2007). Distributive justice. encyclopedia of social psychology.

Nakagawa, Y. and R. Shaw (2004). Social capital: A missing link to disaster recovery. International Journal of Mass

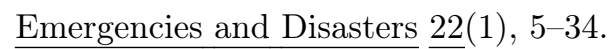

Norris, F. H., S. P. Stevens, B. Pfefferbaum, K. F. Wyche, and R. L. Pfefferbaum (2008). Community resilience as a metaphor, theory, set of capacities, and strategy for disaster readiness. American journal of community $\underline{\text { psychology }} \underline{41}(1), 127-150$.

Ostrom, E. (1990). Governing the commons: The evolution of institutions for collective action. Cambridge university press.

Pancotto, F. and S. Righi (2021). Reflectivity relates differently to pro sociality in naïve and strategic subjects. $\underline{\text { Scientific reports }} \underline{11}(1), 1-15$.

Patterson, O., F. Weil, and K. Patel (2010). The role of community in disaster response: conceptual models. Population $\underline{\text { Research and Policy Review }} \underline{29}(2), 127-141$.

Putnam, R. D., R. Leonardi, and R. Y. Nanetti (1994). Social capital and institutional success. In Making democracy work, pp. 163-186. Princeton University Press.

Rand, D. G. and M. A. Nowak (2011). The evolution of antisocial punishment in optional public goods games. Nature $\underline{\text { communications }} \underline{2}, 434$.

Rao, L.-L., R. Han, X.-P. Ren, X.-W. Bai, R. Zheng, H. Liu, Z.-J. Wang, J.-Z. Li, K. Zhang, and S. Li (2011). Disadvantage and prosocial behavior: The effects of the wenchuan earthquake. Evolution and Human Behavior 32(1), $63-69$.

Renschler, C. S., A. E. Frazier, L. A. Arendt, G. P. Cimellaro, A. M. Reinhorn, and M. Bruneau (2010). A framework for defining and measuring resilience at the community scale: The PEOPLES resilience framework. MCEER Buffalo.

Russo, M. and F. Pagliacci (2019). Reconstruction after an earthquake: Learning from the past. the case study of emilia-romagna. Scienze Regionali $\underline{18}(3), 523-530$.

Tierney, K. (2006). Foreshadowing katrina: Recent sociological contributions to vulnerability science. Contemporary Sociology $\underline{35}(3), 207-212$.

UNDRR (2019). Global assessment report on disaster risk reduction.

Vardy, T. and Q. D. Atkinson (2019). Property damage and exposure to other people in distress differentially predict prosocial behavior after a natural disaster. Psychological Science 30(4), 563-575.

Veszteg, R. F., Y. Funaki, and A. Tanaka (2015). The impact of the tohoku earthquake and tsunami on social capital in japan: Trust before and after the disaster. International Political Science Review $\underline{36}(2), 119-138$.

Wachinger, G., O. Renn, C. Begg, and C. Kuhlicke (2013). The risk perception paradox-implications for governance and communication of natural hazards. Risk analysis $\underline{33(6), 1049-1065 .}$ 
Weil, F. D., H. M. Rackin, and D. Maddox (2018). Collective resources in the repopulation of new orleans after hurricane katrina. Natural Hazards 94(2), 927-952.

Whitt, S. and R. K. Wilson (2007). Public goods in the field: Katrina evacuees in houston. Southern Economic $\underline{\text { Journal }} \underline{74}(2]), 377-387$.

WVS (2020). World value survey. 


\section{Cooperation, fairness and civic capital after an earthquake: Evidence from two Italian regions Supplementary Material}

Francesca Giardini ${ }^{1}$, Francesca Pancotto ${ }^{2}$, and Simone Righi ${ }^{2}$

${ }^{1}$ University of Groningen, Department of Sociology

${ }^{2} \mathrm{Ca}$ ' Foscari University of Venice, Department of economics, Fondamenta S. Giobbe, 873, 30121 Venezia (Italy). simone.righi@unive.it

${ }^{3} \mathrm{Ca}$ ' Foscari UUniversity of Modena and Reggio Emilia, Department of Cultural Studies, Modena. f.pancotto@unimore.it

February 9, 2022

\section{Contents}

S1 Experimental design $\quad 2$

S1.1 Data on locations . . . . . . . . . . . . . . . . . 3

S1.2 Sample composition . . . . . . . . . . . . . . . . . . 5

S1.2.1 Embeddeddness index . . . . . . . . . . . . . . 5

S1.3 Timeline of the experiment . . . . . . . . . . . . . . 6

$\begin{array}{ll}\text { S2 Additional statistical analysis } & \mathbf{7}\end{array}$

S2.1 Cross-correlation analysis . . . . . . . . . . . . . . . 7

S2.2 Bayesian Factor analysis of model comparison $\ldots \ldots \ldots . \ldots$

S3 Translation of the Experimental Instructions in English $\quad 9$

S3.1 Survey . . . . . . . . . . . . . . . . . . . . . . . . . . 37

S3.2 Cognitive Reflection Test . . . . . . . . . . . . . . . . . . 43

S3.3 Final Summary . . . . . . . . . . . . . . . . . . . . . . . . . . . 43

S3.4 Instructions in Italian . . . . . . . . . . . . . . . . . . . . . . . 45

S3.5 Results in detail . . . . . . . . . . . . . . . . . . . . . . . 990 90

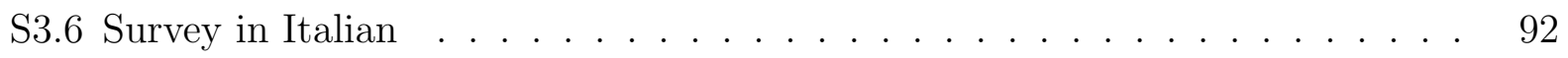




\section{List of Figures}

S1 Resident Population by region and location (smoothed growth rates) . . . . 4

S2 Resident Population by region (growth rates trends) . . . . . . . . . . . 4

S3 Timeline of the experiment . . . . . . . . . . . . . . . 7

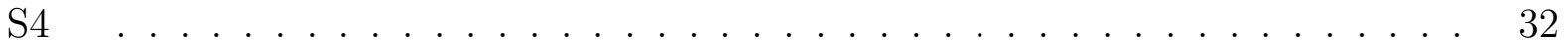

\section{List of Tables}

S1 Demographic, geographic and behavior data on locations from Institutional sources . . . . . . . . . . . . . . . . . . . . 4

S2 Macro data on on locations . . . . . . . . . . . . . . . 5

S3 Demographics of the Sample . . . . . . . . . . . . . . . 5

S4 Embeddedness index: disaggregated data . . . . . . . . . . . . . 6

S5 Cross Correlations . . . . . . . . . . . . . . . . . . 8

S6 Bayes factor analysis: dependent variable PGG. Against denominator: Intercept only . . . . . . . . . . . . . . . . . . . . . . . 9

S7 Bayes factor analysis: dependent variable DisG. Against denominator: Intercept only . . . . . . . . . . . . . . . . . . . . 9

\section{S1 Experimental design}

In principle, our study relates to the literature on cross-cultural experiments carried out with samples selected and compared across different countries (Herrmann et al., 2008; Henrich et al., 2001, 2010; Grimalda et al., 2015) but more specifically to contributions exploring the roots of differential cooperation behavior behavior across samples selected within the same country, such as Lamba and Mace (2011) and Bigoni et al. (2016), although with a different scope, i.e. studying regional differences in cooperation and fairness that emerge as a result of the experience of a dramatic event.

We select a general sample of the population with the specific aim to perform a comparison between communities similar in cultural roots but different by the level of impact that the event has caused on their lives. For this reason, this sample is similar to Bigoni et al. (2016), as it is intended to capture a group of citizens with a wider spectrum of demographic characteristics with respect to the classical students' sample. On the other hand, we did not reproduce a representative sample of the population with respect to the general Italian population, as in Bigoni et al. (2016) given that we had a stricter selection criterion, i.e. being inside or outside the seismic area, with the further issue that the localities where the event happened, were in some cases small villages with few inhabitants. 
For this reason in Section S1.1 we describe some features of the localities selected for the experiment, while in Section S1.2 we describe in detail the demographics of the sample selected, including also a specific analysis of the embeddeddness index used in the main text. In Section S1.3 a detailed timeline of the whole experiment is reported.

\section{S1.1 Data on locations}

In our design we have collected data at the level of location with the intention to capture a comparative sample of people affected and not affected by the disaster, by selecting them in locations officially included in the list of localities being part of the seismic area, i.e. ISA (Inside seismic area) and excluded OSA(outside seismic area). To give the reader more insights in the characteristics of the localities selected, we draw a general picture of the localities in terms of GDP, Population, and also geographical features. We could in principle include these data points in the regressions ${ }^{1}$ but the low variability with respect to the general sample does not permit to use them in the statistical analysis. However, we believe it is important to describe them.

We collected data of yearly population by city and calculated the change in resident population from year 2009 to 2018, last available data point ${ }^{2}$, a time span that includes both earthquakes, the 2012 in Emilia and the 2016 in Marche.

In Table $\mathrm{S} 2$ we report data on the variation of GDP per capita in the period spanning the two earthquake, i.e. between 2011 and 2017, and also the mean population change per region. Then we explore in detail these figures at city level, including city dimension, income, population change, compared with mean contribution in the PGG.

Figure S1 reports the (smoothed) growth rate of the population on the locations where experiments were run. At first look, the cities of Emilia-Romagna show a very similar pattern, with a peak in 2014 which was falling in the following years but then rising again. In Marche we observe a more inconsistent trend, which is to be expected considering the higher diversity between towns there. Generally, the trend in population growth is positive in Emilia-Romagna, while it is negative in Marche. This trend is confirmed calculating the population growth of all locations in each region as reported in Figure S2 where a linear smoothing function is used.

\footnotetext{
${ }^{1}$ And we did, but they were never significant.

${ }^{2}$ Data are from Istat, Istituto di Statistica Nazionale, https://www.istat.it
} 
Figure S1: Resident Population by region and location (smoothed growth rates)

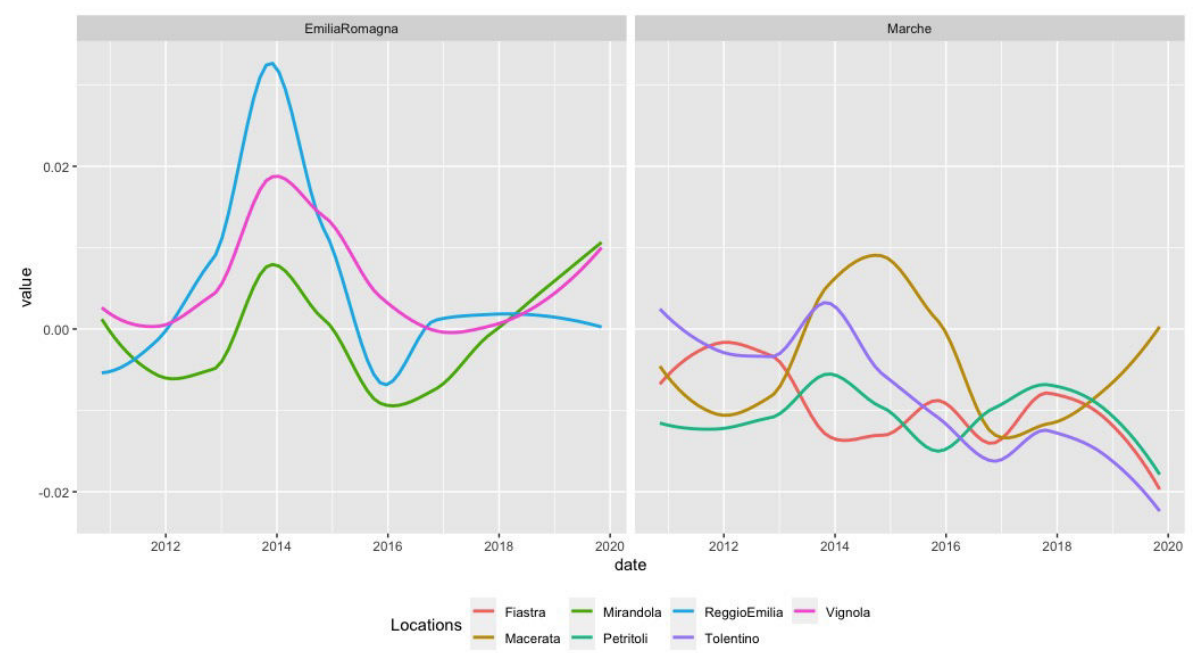

Figure S2: Resident Population by region (growth rates trends)

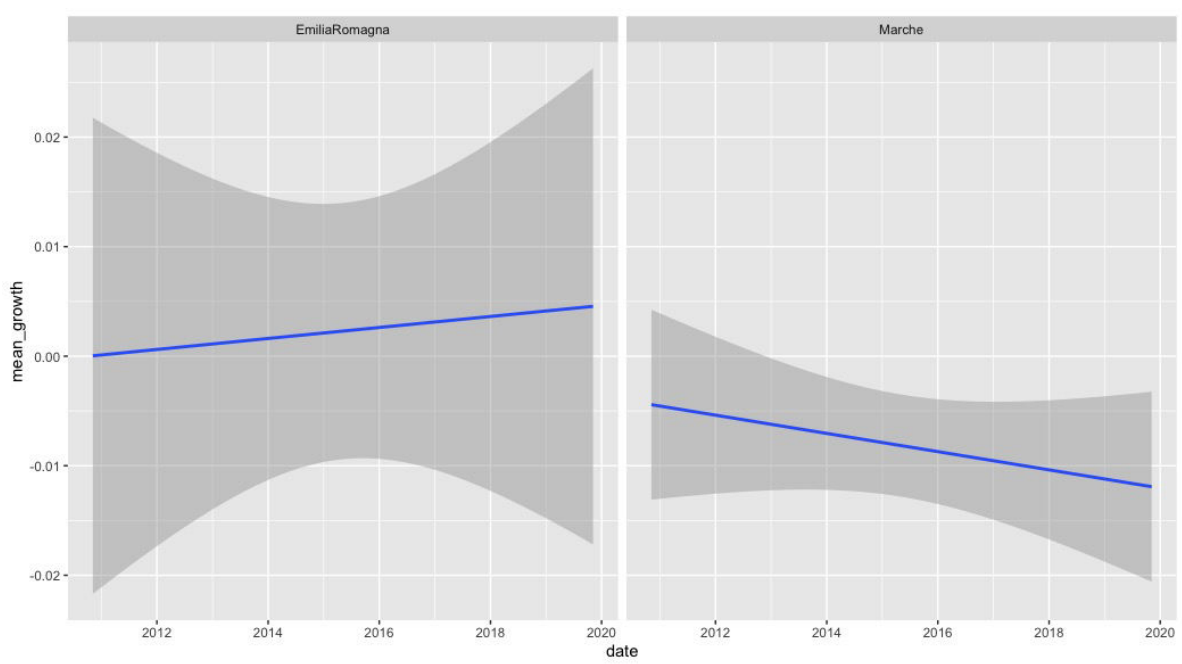

Table S1: Demographic, geographic and behavior data on locations from Institutional sources

\begin{tabular}{|c|c|c|c|c|c|c|c|c|c|}
\hline & Mirandola & Reggio Emilia & Vignola & Petritoli & Macerata & Fiastra & Tolentino & Year & Source \\
\hline Municipality Population & 24091 & 172124 & 25717 & 2236 & 41163 & 664 & 18858 & 2020 & ISTAT \\
\hline Population density $\left(\mathrm{pop} / \mathrm{km}^{2}\right)$ & 175.73 & 746.22 & 1124.978 & 93.166 & 444.861 & 11.513 & 198.254 & 2020 & ISTAT \\
\hline \# of Foreign Citizens & 3654 & 28709 & 4633 & 189 & 4334 & 53 & 1734 & 2020 & ISTAT \\
\hline$\%$ Foreign citizens & 0.15 & 0.16 & 0.18 & 0.084 & 0.10 & 0.077 & 0.09 & 2020 & ISTAT \\
\hline Latitude & $44 \neg \infty 53^{\prime} N$ & $44 \neg \infty 42^{\prime} N$ & $44 \neg \infty 28^{\prime} N$ & $43 \neg \infty 04^{\prime} N$ & $43 \neg \infty 39^{\prime} N$ & $43 \neg \infty 02^{\prime} N$ & $43 \neg \infty 12^{\prime} N$ & 2011 & ISTAT \\
\hline City Elevation (a.m.s.l) & 14 & 56 & 130 & 211 & 161 & 886 & 135 & 2011 & ISTAT \\
\hline Taxable income p.c. (euro) & 16801.54 & 16634.81 & 16338.91 & 11386.07 & 15843.54 & 12364.94 & 13745.93 & 2020 & ISTAT \\
\hline Referendum turnout (\%) & 0.54 & 0.54 & 0.71 & 0.67 & 0.74 & 0.69 & 0.6855 & 20.2 & Min. of Int. \\
\hline \# Taxpayers & 18464 & 123741 & 19012 & 1717 & 31183 & 514 & 14174 & 2018 & $\mathrm{MEF}$ \\
\hline Surface of the municipality $\left(\mathrm{km}^{2}\right)$ & 137.09 & 230.66 & 22.86 & 24 & 92.53 & 57.67 & 95.12 & 2013 & ISTAT \\
\hline
\end{tabular}


Table S2: Macro data on on locations

\begin{tabular}{lrrlrr}
\hline Region & $\begin{array}{r}\Delta \% \text { GDP } \\
\text { (percap) }\end{array}$ & $\begin{array}{r}\Delta \% \text { Pop } \\
\text { mean }\end{array}$ & City & $\begin{array}{r}\text { Income } \\
\text { (p.c.) }\end{array}$ & $\begin{array}{r}\text { Pop. growth } \\
\text { \%change }\end{array}$ \\
\hline Marche & -0.7 & -0.817 & Fiastra & 7900 & -0.878 \\
$2011-2017$ & & & Tolentino & 10234 & -0.852 \\
& & & Petritoli & 8075 & -1.111 \\
& & & Macerata & 12545 & -0.427 \\
Emilia & \multirow{2}{*}{+0.2} & Mirandola & 12582 & -0.087 \\
$2011-2017$ & & & ReggioEmilia & 14023 & 0.286 \\
& & & Vignola & 12745 & 0.488 \\
\hline
\end{tabular}

\section{S1.2 Sample composition}

In Table S3 we report the composition of the sample of participants selected for our experiment in detail. First, by column we subdivide participants by the demographics classes used for the selection, i.e. by gender, age and employment status. By row, we also subdivide participants in subgroup by region and within the region, by location. At the bottom of the table, for each location date and time of each session is registered.

Table S3: Demographics of the Sample

\begin{tabular}{|c|c|c|c|c|c|c|c|c|}
\hline & $\begin{array}{l}\text { Emilia Romagna } \\
\text { Mirandola }\end{array}$ & Reggio Emilia & Vignola & $\begin{array}{l}\text { Marche } \\
\text { Fiastra }\end{array}$ & Macerata & Petritoli & Tolentino & Total \\
\hline \multicolumn{9}{|l|}{ Gender } \\
\hline Male & 31 & 13 & 17 & 4 & 5 & 17 & 6 & 93 \\
\hline Female & 49 & 50 & 13 & 8 & 7 & 18 & 9 & 154 \\
\hline $\mathrm{NA}$ & 0 & 1 & 2 & 0 & 0 & 1 & 1 & 5 \\
\hline \multicolumn{9}{|l|}{ Age Class } \\
\hline $18-24$ & 21 & 35 & 10 & 2 & 2 & 4 & 3 & 81 \\
\hline $25-34$ & 24 & 14 & 4 & 2 & 4 & 6 & 0 & 53 \\
\hline $35-49$ & 14 & 9 & 2 & 5 & 2 & 7 & 7 & 51 \\
\hline $50-65$ & 18 & 3 & 8 & 2 & 4 & 10 & 3 & 42 \\
\hline $65+$ & 0 & 0 & 8 & 0 & 0 & 8 & 2 & 16 \\
\hline NA & 3 & 3 & 0 & 1 & 0 & 1 & 1 & 9 \\
\hline \multicolumn{9}{|c|}{ Employment status } \\
\hline Employed & 49 & 25 & 8 & 8 & 5 & 20 & 6 & 121 \\
\hline Unemployed & 5 & 4 & 1 & 2 & 0 & 2 & 2 & 16 \\
\hline Retired/Housekeeper & 3 & 1 & 11 & 0 & 2 & 3 & 4 & 29 \\
\hline Student & 23 & 33 & 11 & 2 & 5 & 5 & 3 & 82 \\
\hline $\mathrm{NA}$ & 0 & 1 & 1 & 0 & 0 & 1 & 1 & 4 \\
\hline Participants & 80 & 64 & 32 & 12 & 12 & 36 & 16 & 252 \\
\hline \multicolumn{9}{|l|}{ Sessions } \\
\hline & 09-04-2016 h. 14.00 & $12-03-2016$ h. 14.30 & 26-11-2015 h. 14.30 & 16-12-2017 h $16: 00$ & $19-5-2017$ h. 15.00 & 2-08-2017 h. 8.00 & 17-5-2018 h.16:00 & \\
\hline & $09-04-2016$ h. 16.00 & $28-05-2016$ h. 11.00 & 26-11-2015 h. 16.30 & & & 2-08-2017 h. 15.00 & & \\
\hline & $23-04-2016$ h. 11.00 & $28-05-2016$ h. 14.30 & & & & $21-10-2017$ h. 10.30 & & \\
\hline & $23-04-2016$ h. 14.00 & $28-05-2016$ h. 16.30 & & & & & & \\
\hline & 23-04-2016 h. 16.00 & & & & & & & \\
\hline
\end{tabular}

\section{S1.2.1 Embeddeddness index}

In the selection of the sample of participants invited to participate in the experiment, we imposed a list of criteria which should guarantee that those playing in the lab were actual inhabitants that could be associated at some level with the cultural identity of the location selected. First, All the participants were resident in the village, town or city selected in the 
design, at the time of the experiment. To control the degree at which we achieved this goal, we asked in the post experiment survey, four questions concerning the individual, namely: whether the participant was born in the location, the birthplace of the mother and the father and the location the participant attended primary school. We asked parents' birthplace as a proxy of family roots and the location of attendance of primary school as an indicator of primary socialization, which would happen within that community or elsewhere. We created an indicator of embeddedness based on these responses. The embeddedness index ranges between 4 - when the participant is born in the region, has gone to primary school in the region and his mother and father are born in the region as well - and 0 if neither she/he nor the parents were born in the region, and she/he did not go to elementary school there. This indicator generates a discrete variable that measures approximately the degree of embeddedness of the participant.

Table S4: Embeddedness index: disaggregated data

\begin{tabular}{|c|c|c|c|c|c|c|c|}
\hline \multirow[t]{3}{*}{ embeddedness } & \multirow{2}{*}{\multicolumn{3}{|c|}{ Emilia Romagna }} & \multirow{2}{*}{\multicolumn{4}{|c|}{ Marche }} \\
\hline & & & & & & & \\
\hline & Mirandola & Reggio Emilia & Vignola & Fiastra & Macerata & Petritoli & Tolentino \\
\hline Born in the Region & 63 & 41 & 29 & 2 & 5 & 10 & 1 \\
\hline$\%$ on Region Total & \multicolumn{3}{|c|}{ Emilia Romagna: $76 \%$ (on 176) } & \multicolumn{4}{|c|}{ Marche: $24 \%($ on 76$)$} \\
\hline Mother born in the Region & 52 & 34 & 27 & 4 & 2 & 10 & 1 \\
\hline$\%$ on Region Total & \multicolumn{3}{|c|}{ Emilia Romagna: $64 \%$ (on 176) } & \multicolumn{4}{|c|}{ Marche: $23 \%($ on 76$)$} \\
\hline Father born in the Region & 59 & 27 & 27 & 3 & 4 & 11 & 1 \\
\hline$\%$ on Region Total & \multicolumn{3}{|c|}{ Emilia Romagna: $64 \%$ (on 176) } & \multicolumn{4}{|c|}{ Marche: $26 \%($ on 76$)$} \\
\hline Element. school in the Region & 66 & 53 & 31 & 5 & 5 & 13 & 1 \\
\hline$\%$ on Region Total & \multicolumn{3}{|c|}{ Emilia Romagna: $85 \%$ (on 176 ) } & \multicolumn{4}{|c|}{ Marche: $32 \%($ on 76$)$} \\
\hline
\end{tabular}

In the main text we use this embeddeddness index as an indicator of the family roots of the participants in the general analysis, while here in Table S4 we report detailed data on the responses, both at the level of the region, of the city as well as separated by response. In the Table we observe that participants selected in Emilia Romagna are on average more often born in the region, have parents born in the region and attended primary school in the region. This suggests that our Emilia sample present participants more rooted in the society where they live and consequently higher levels of the embeddeddness indicator that we implemented in our analysis.

\section{S1.3 Timeline of the experiment}

The time line of the whole experiment consists of a sequence of tasks proposed to the same pool of subjects. After each task, new groups of subjects are formed, randomly selected 
among all the participants present in the room. Participants are each time reminded of this reshuffling. No feedback is given to participants at the end of each task. In Figure S3 we report the general time line of the whole experiment and the reshuffling is drawn with a snake sign. In the current paper, only data related to the PGG, DisG and SURVEY are analysed, while the data of the remaining tasks (OPT PGG and GG) are studied in companion papers (Pancotto and Righi, 2021; Pancotto et al., 2020).

Figure S3: Timeline of the experiment

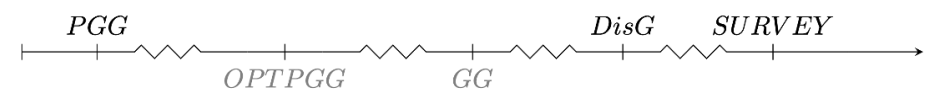

\section{S2 Additional statistical analysis}

\section{S2.1 Cross-correlation analysis}

As preliminary analysis, we control cross-correlations among all sets of data considered, i.e. PGG choices, DisG preferences, and the three sets of data from survey questions, i.e. civic capital, damage, trust and embeddedness, plus two demographics controls namely employment and age. This preliminary analysis is important to eliminate endogeneity among regressors that could artificially inflate the significance of regressors.

The first observation is that all variables related to pro social behavior, i.e. PGG, DG, and CK_IDX are not correlated with the dummies that identify the presence inside the earthquake seismic area (ISA). Looking at single variables, PGG is correlated with DisG and CK variables, for what concerns survey answers, with current habitability and trust.

On the contrary, DisG choices do not correlate with CK while showing correlation with damage variables (current habitability of the house). Third, CK_IDX variable presents correlations with trust questions: these two groups of responses constitute the definition of civic capital according to Guiso et al. (2011). Their correlation confirms that our measure is consistent with their definition.

Finally, all survey variables related to the earthquake are correlated with being present at the moment of the disaster and resident in the area of the earthquake i.e., amount of damage, habitability of the house, post disaster recovery, which confirms that our selection 
has captured a sample of the population effectively influenced by the event. For this reason we use only one out of them, i.e. current habitability of the house, as an indicator of how much the household was negatively affected by the earthquake. In addition, the questions about trust and honesty are highly correlated between them, so we will use just one of the two in a regression analysis.

Table S5: Cross Correlations

\begin{tabular}{|c|c|c|c|c|c|c|c|c|c|c|c|c|c|}
\hline & PGG & DisG & CK_IDX & crater & residence_terr_01 & post_sisma & damage_class & current_habitability & people_honest & people_trustable & embeddedness & employed & age \\
\hline PGG & 1.00 & $0.12^{* *}$ & $0.15^{* * *}$ & 0.01 & -0.08 & -0.01 & 0.10 & $-0.14^{* *}$ & 0.09 & $0.15^{* * *}$ & -0.15 & $0.15^{* * *}$ & $0.19^{* * * *}$ \\
\hline DisG & $0.12^{* *}$ & 1.00 & -0.06 & 0.08 & 0.10 & 0.09 & $0.15^{* *}$ & $-0.13^{* *}$ & -0.06 & -0.05 & -0.03 & -0.00 & $-0.12^{* *}$ \\
\hline CK & $0.15^{* * *}$ & -0.06 & 1.00 & 0.08 & 0.02 & $0.11^{*}$ & $0.13^{* *}$ & $-0.11^{*}$ & $0.17^{* * *}$ & $0.15^{* * *}$ & 0.02 & $0.40^{* * *}$ & $0.39^{* * *}$ \\
\hline ISA & -0.08 & 0.10 & 0.02 & $0.57^{* * *}$ & 1.00 & $0.31^{* * * *}$ & $0.26^{* * *}$ & $-0.21^{* * * *}$ & -0.09 & -0.10 & 0.00 & 0.10 & -0.02 \\
\hline post_sisma & -0.01 & 0.09 & $0.11^{*}$ & $0.50^{* * *}$ & $0.31^{* * *}$ & 1.00 & $0.64^{* * *}$ & $-0.46^{* * *}$ & -0.08 & -0.07 & 0.07 & 0.06 & 0.08 \\
\hline damage_class & 0.10 & $0.15^{* *}$ & $0.13^{* *}$ & $0.47^{* * *}$ & $0.26^{* * *}$ & $0.64^{* * *}$ & 1.00 & $-0.75^{* * *}$ & -0.00 & -0.04 & -0.13 & 0.06 & $0.19^{* * * *}$ \\
\hline current_habitability & $-0.14^{* *}$ & $-0.13^{* *}$ & $-0.11^{*}$ & $-0.32^{* * *}$ & $-0.21^{* * *}$ & $-0.46^{* * *}$ & $-0.75^{* * *}$ & 1.00 & $-0.13^{* *}$ & 0.03 & 0.13 & $-0.14^{* * *}$ & $-0.19^{* * *}$ \\
\hline people_honest & 0.09 & -0.06 & $0.17^{* * *}$ & -0.11 & -0.09 & -0.08 & -0.00 & $-0.13^{* *}$ & 1.00 & $0.41^{* * * *}$ & -0.01 & 0.01 & $0.40^{* * * *}$ \\
\hline people_trustable & $0.15^{* * *}$ & -0.05 & $0.15^{* * *}$ & $-0.16^{* * *}$ & -0.10 & -0.07 & -0.04 & 0.03 & $0.41^{* * *}$ & 1.00 & 0.16 & $0.13^{* *}$ & $0.30^{* * * *}$ \\
\hline embeddedness & -0.15 & -0.03 & 0.02 & -0.18 & 0.00 & 0.07 & -0.13 & 0.13 & -0.01 & 0.16 & 1.00 & 0.03 & -0.13 \\
\hline employed & $0.15^{* * * *}$ & -0.00 & $0.40^{* * *}$ & $0.18^{* * *}$ & 0.10 & 0.06 & 0.06 & $-0.14^{* * * *}$ & 0.01 & $0.13^{* *}$ & 0.03 & 1.00 & $0.22^{* * * *}$ \\
\hline age & $0.19^{* * *}$ & $-0.12^{* *}$ & $0.39^{* * * *}$ & 0.03 & -0.02 & 0.08 & $0.19^{* * * *}$ & $-0.19^{* * *}$ & $0.40^{* * * *}$ & $0.30^{* * * *}$ & -0.13 & $0.22^{* * *}$ & 1.00 \\
\hline
\end{tabular}

\section{S2.2 Bayesian Factor analysis of model comparison}

In order to select the best among the estimated models, we apply a Bayesian factor approach calculating the Bayes factor for all models of interest against the null, the interceptonly. More specifically, we perform a model comparison in multiple linear regression using BayesFactor via the approach of Liang et al. (2008) and implementing the Bayes Factor package in R by Richard D. Morey and Jeffrey N. Rouder.

We run this test for both the models of PGG and DisG reported in the main text. The Bayesian analysis calculates all possible models (63 in this case) that can be created given the selected regressors and then presents a ranking of the models according to the Bayes factor scored. Hence we selected the 6 models with the highest value of the Bayes factor and checked if the proposed model are in line with significance of regressors obtained with the frequentist analysis reported in the main text.

For the PGG, the highest BF (Bayes Factor) is for a model including DisG and age only, with a BF equal to 9.16, which is a pretty high value of the BF suggesting high confidence in the results (see Table S6). However, our model in the main analysis includes also the civic capital indicator variable and the habitability dummy which are important variables to include for the purpose of our research. This model still scores quite well achieving a BF of 5.15 which suggests a moderate evidence in its favor. However, the inclusion of habitability does imply a lower BF with respect to the better model, which suggests us that for the PGG the correlation with the variable is not as strong as for the DisG, although present. 
Table S6: Bayes factor analysis: dependent variable PGG. Against denominator: Intercept only

\begin{tabular}{l|ll}
\hline no & Model & Bayes Factor \\
\hline 1 & DisG + age & 9.168373 \\
2 & DisG + habitability + age & 7.419984 \\
3 & ck + DisG + age & 6.62782 \\
4 & ck + DisG + habitability + age & 5.510355 \\
5 & habitability + age & 4.905497 \\
6 & age & 4.18957 \\
\hline
\end{tabular}

Table S7: Bayes factor analysis: dependent variable DisG. Against denominator: Intercept only

\begin{tabular}{c|ll}
\hline no & Model & Bayes Factor \\
\hline 1 & PGG + habitability + age & 6.004535 \\
2 & habitability + age & 3.956333 \\
3 & PGG + age & 2.98295 \\
4 & PGG + RegionMARCHE + habitability + age & 1.845828 \\
5 & PGG + habitability + RegionEMILIA + age & 1.845828 \\
6 & PGG + ck + habitability + age & 1.711646 \\
\hline
\end{tabular}

For what concerns the DisG, the best model selected by the procedure is the one including PGG, habitability and age, which are the variables selected in our frequentist regression analysis, with a BF of 6, supporting moderate evidence in favour of the model against the intercept only model (Table S7). Models for the PGG with the inclusion of the Region dummies (row 4) score relatively well in terms of BF, supporting the idea of a significant difference in the values of the DisG between the two regions.

\section{S3 Translation of the Experimental Instructions in En- glish}

\section{Tablet use}

This page has the aim to help you to understand how the device you are using works. The screen of the device in front of you is sensitive to the touch of fingers. Scroll down the page. Since some pages contain more text than can be displayed in the screen, you need to scroll down the page.

If you place one finger on the screen of the device and try to move it vertically, the page will 
scroll accordingly.

Take a few minutes to become familiar with this mechanism if you don't know it well.

The test in the yellow box below is useless, it serves the only purpose to familiarize you with process of page scrolling on this device.

When you are ready for the next instructions scroll down, below the text in the yellow box.

\section{YELLOW BOX WITH A LONG 'LOREM IPSUS' TEXT.}

In addition to reading the instructions (shown in yellow boxes similar to the above ones), this study requires two types of activities:

In the first one, you are asked questions requiring you to enter a number. By clicking on the empty box close to the question, you will see a numeric keypad. You can enter numbers through it. To check if you understand, now enter number 42 as a response to the following question:

\section{Which number comes after 41? BOX FORM}

The last type of activity required to complete this study consists in the selection of ONE among several possible answers. In all the questions proposed in this format, you can choose only one option at a time, clicking with the tip of the finger on one of the answers.

You can choose any available answer and you can change your answer any time you want just clicking on the new answer.

Take a few minutes experience with the process of selecting responses and, when you're sure that you have understood, select the second answer to show you understand the operation.

This is an example of multiple choice question. Select the second answer.

1. This is not the correct answer

2. Click on this answer to confirm that you understand

3. Incorrect answer

4. Incorrect answer too

5. Wrong answer

Finally, this study consists of a series of pages in succession. You can change your an- 
swers whenever you want and, when you are sure of your choice on that page, you have to click on "next" to continue.

Once you have clicked on "next", you can not go back and change your choices.

When you're ready and feel confident in using this device, click on "next" to start the real study.

\section{Welcome}

Welcome!

First, thank you for participating in this study organized by the University of Modena and Reggio Emilia, in collaboration with the University o Macerata.

We inform you that at the end of the study you will be rewarded of 5 euro for your participation and of a further bonus depending of the choices you and other participants in this room will make. You will receive the reward at the end of the study, in private.

We ask you to turn off your phone. From this moment, no conversation among people in this room is allowed and communication with people outside the room is forbidden.

If you have doubts or questions to ask, at any time during the course of the study, please do not hesitate to raise you hand and one of us will come from you to clarify any doubts.

It's very important to follow the instructions carefully. During the instructions, we will use some numerical examples to illustrate more clearly the choices to be made. Those examples are not relevant for your final reward.

The survey consists of 5 parts. In each of these 5 parts, you'll be part of a group. Besides you, the group will consist of three other people. The composition of the group is anonymous. You will never be able to know who is part of your group as well as the others will never know who is in theirs. The group composition will change in each part of the study. For each part the computer will do a random draw and establish the new group you will join.

During the study, you will be asked to take decisions. Each decision can be changed any time you want, before clicking "next" at the end of the page.

When you have clicked on "next", the last decision you've selected becomes the final one. From this point on, your reward will be expressed in token/points. Every token/point is 
equal to 0,04 euro.

Click on "next" when you're ready to start.

\section{First part - Instructions}

In this part of the study, you have to make decisions that will affect your final compensation, depending on your choice and the one given by other members of the group.

Now, the computer will stop groups of 4 participants in which you will be part of, randomly and anonymously.

Click on "next" to continue.

\section{First part - Instructions}

\section{INSTRUCTIONS}

You have access to 40 tokens and you have to choose how many hold in your private account and how many put in a common project. You can choose on of the following values: 0, 10, 20, 30, 40 and you cannot choose intermediate values like 15, 23, 39.

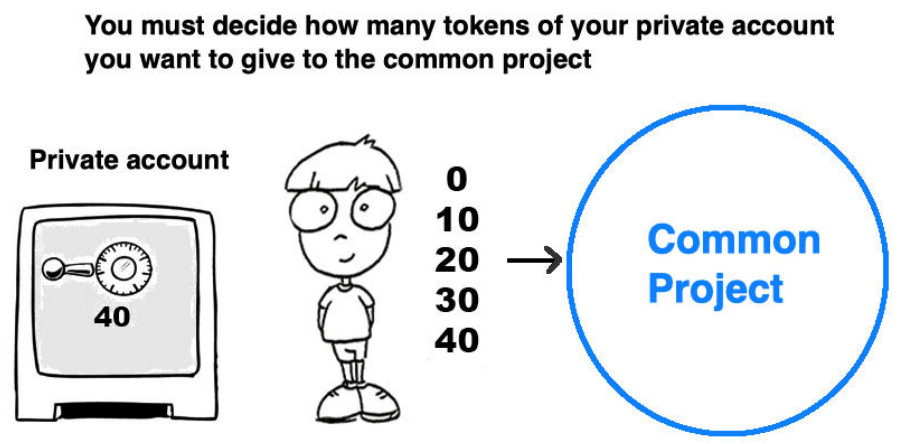

Pay attention! You can choose only one among the following five values: 0, 10, 20, 30, 40.

The tokens you do not put in the common project remain in your private account. The token you put in the common project are doubled and then divided equally between 4 members of the group, regardless of the number of tokens that everyone has put in the common 
project.

\section{LET MAKE SOME EXAMPLES}

Example 1: If every member of your group put all their 40 token in the common project, the remuneration of all will doubles: you all will get 80 tokens. This because if every members of your groups put 40 tokens in the common project, the common project value becomes 40 $\mathrm{x} 4=160$ tokens.

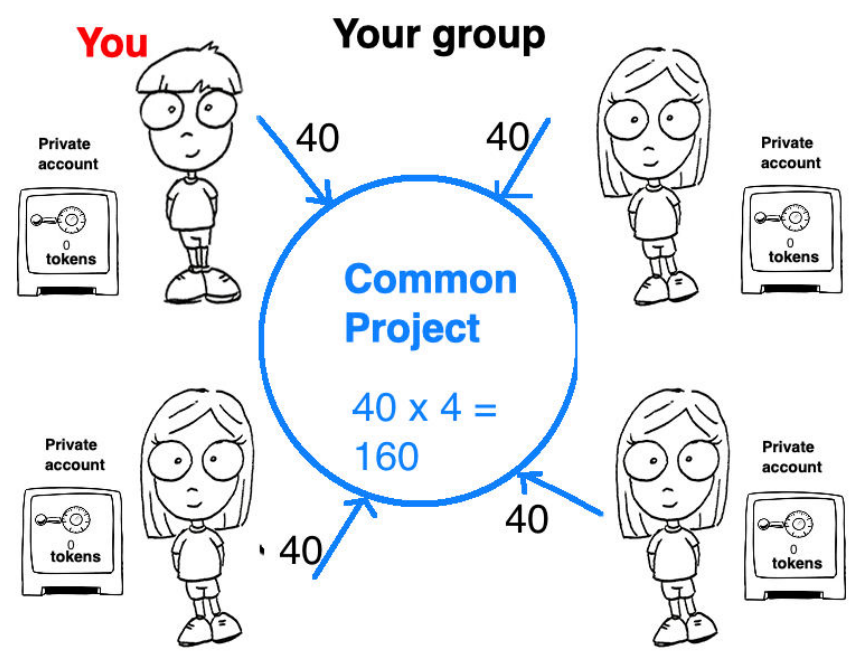

The 160 tokens put in the common project are multiplied for 2 and divided equally between four participants, $320: 4=80$ for each, you included.

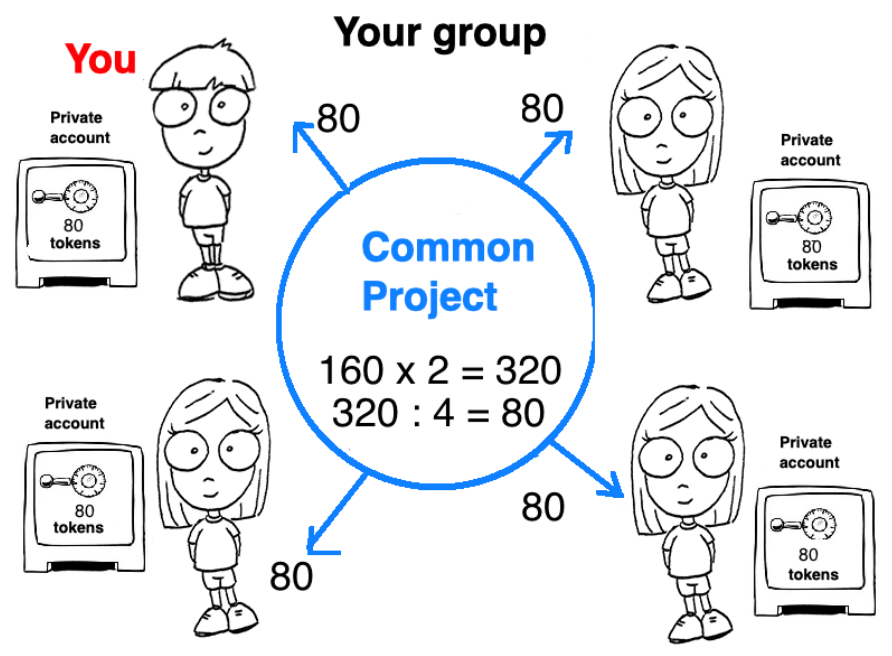


Example 2: If all the members of your group put their 40 tokens, while you keep for yourself your 40 tokens, the 40 tokens will remain in your private account and none will be contributed to the common project.

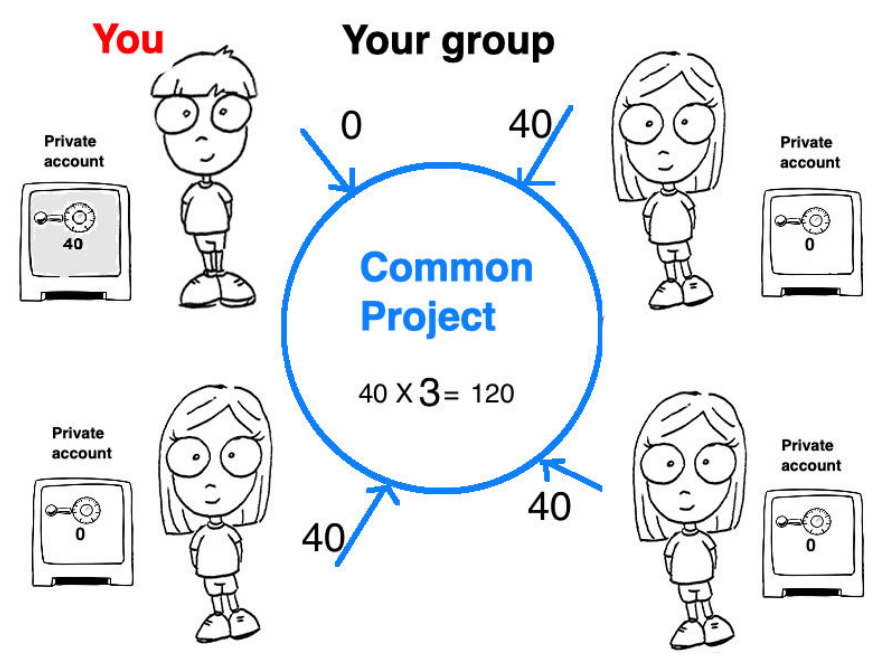

The total value of the project will be $40 x 3=120$, that multiplied by two will produce the final value of 240 . The final value of the common project will be equally divided among the four components for the group. So everyone will obtain $240: 4=60$ from the common project, you included.

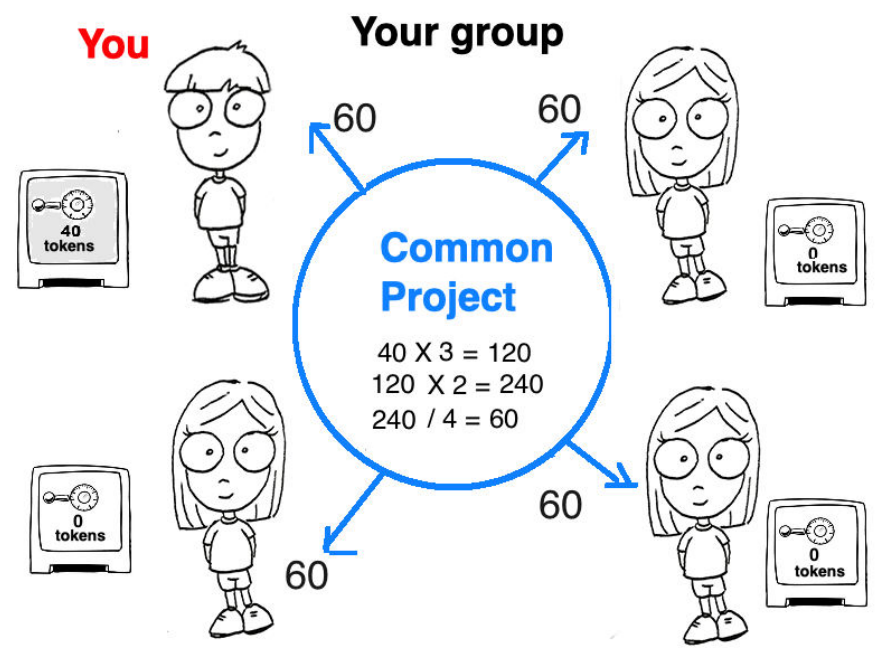

In this case you will obtain your 60 tokens from the common project, plus the 40 tokens that you kept in your private account, thus a total of 100 tokens, while the other components of the group will obtain only the 60 tokens from the common project. 


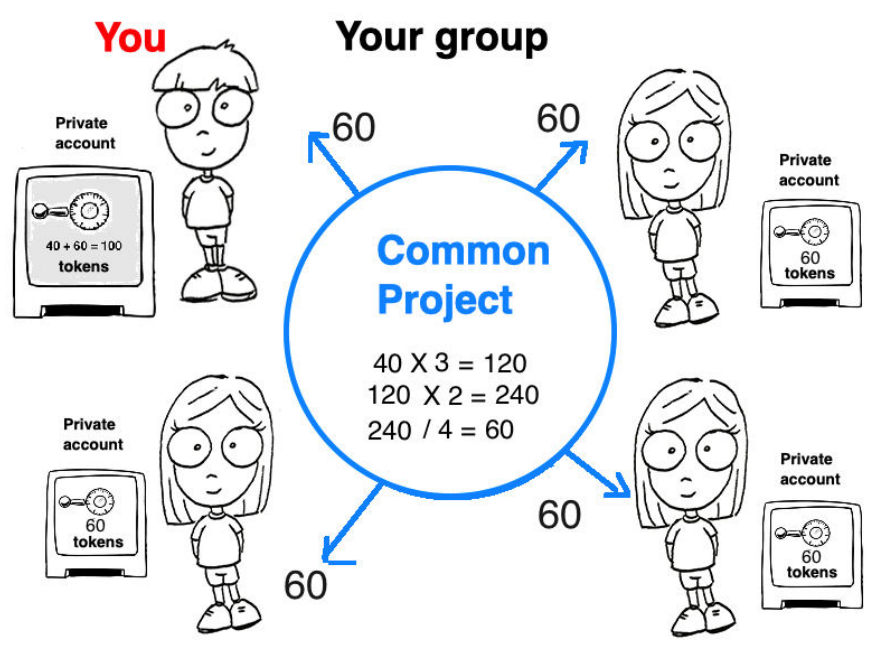

Is everything clear?

Are there any questions?

The instructions will remain available for the length of this part of the study by clicking on "Click to reading the instructions".

To help you to make sure you have understood the instructions correctly, in the next page we ask you to answer some questions that WILL NOT EFFECT your final remuneration. Click "Next" to continue.

\section{First Part - Training Questions}

Imagine that all other members of your group put in the common project 0,20 and 30 coins, while you put 10 coins.

The total value of the common project, after everybody decision on contribution is:

- A: $0+20+30+10=60$

- B: $0+20+30+10=60 \times 2=120$

The individual reward obtained ONLY from the common project, after everybody has contributed is:

- A: $60: 4=15$ 
- B: $120: 4=30$

Your final reward is:

- A: $120: 4=30$

- B: $120: 4=30+$ your coins in the wallet equal to $30(=40$ initial coin -10 you put in the common project). Total 60 .

Click "next" to continue.

\section{First Part - Answer to the training questions}

Your answer 'The value of the common project after everybody has decided how much to put is: $\mathrm{B}: 0+20+30+10=60 \times 2=120$ ' was wrong.

Your answer 'The individual reward from ONLY the common project, after everybody contributed is: B: $120: 4=30$ ' was correct.

Your answer 'B: $120: 4=30+$ your coins in the wallet equal to 30 (=40 initial coin -10 you put in the common project). Total 60.' was correct.

Explanation of the first question:

The gain obtained from the common project is equal to 120. Indeed, the sum of the tokens available to the four components of the group is equal to 60 , but since the tokens in the common project double their value, these 60 become $60 \times 2=120$. The correct answer is then 120 .

Explanation of the second question:

The value of the common project is 120 . Since the tokens in the common projects, after being doubled, are divided equally among the 4 components of the group, then the 120 tokens in the common project, divided by 4 give 30 tokens each. The correct answer is then 30 . Explanation of the third question:

The tokens that each component of the group obtains from the common project is 30. You have decided, in this example, to put 10 tokens. So, 30 tokens remained in your private account that, summed with the return from the common project make $30+30=60$. The correct answer was then 60 .

You have completed the training questions, now you can start the real test. 
When you are ready, click on the button "Next" here.

\section{First Part - Decision \\ First Part - Decision}

How many tokens do you put in the common project?

- 0 tokens

- 10 tokens

- 20 tokens

- 30 tokens

- 40 tokens

Click on "next" when you are ready.

\section{Second Part - Instructions}

Now the computer will form, randomly, NEW groups of four participants. As in the First part, in this second part you have to take two decisions.

Click on "next" to continue.

\section{Second Part - First decision - Instructions}

Instructions

As in the First Part, you have 40 tokens available. You have to choose how many tokens to keep in your private account and how many to put in a common project.

As in the previous parts, you have to decide the amount of tokens to put in the common project among the following values: 0, 10, 20, 30, 40 .

What happens after your choice?

As before, the tokens you put in the common project are doubled and then equally divided among the four members of the group.

The tokens that you DON'T put in the common project remain in your private account. 
Attention! In this part you will have the possibility to decide to NOT participate and to obtain a fixed bonus of 40 tokens.

Click on "next" to continue.

\section{Second Part - Second Decisions - Instruction}

\section{Instructions}

In the second decision, you have to choose among three possible actions, A, B or C, to associate to each of the six choices reported below. The three actions A, B and C correspond to:

- Action A: You pay 0 tokens, and the other components of the group loses 0 tokens.

- Action B: You pay 4 tokens, and the other components of the group loses 12 tokens.

- Action C: You pay 8 tokens, and the other components of the group loses 24 tokens.

\section{Decision 2}

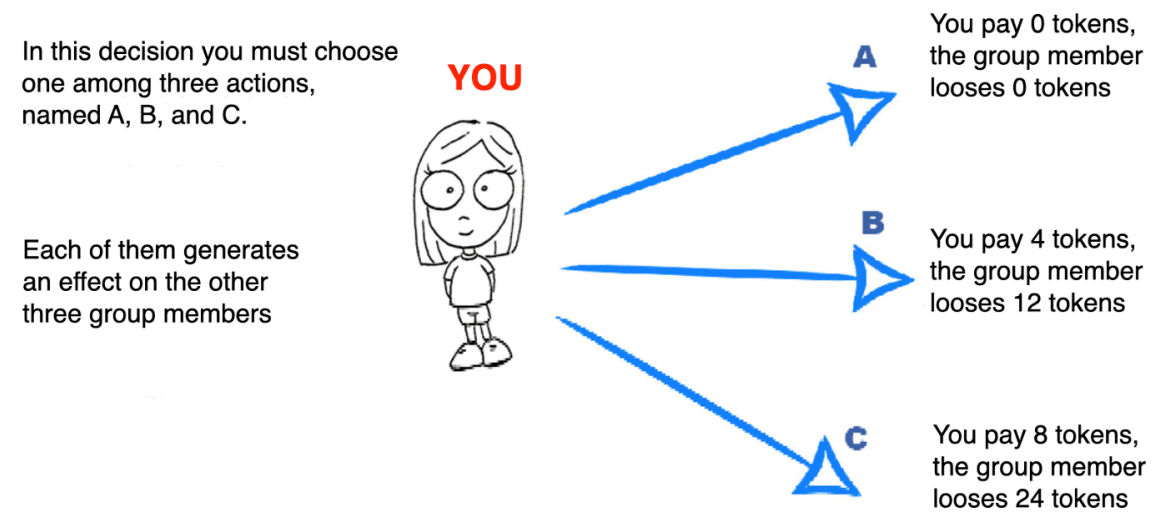

You are asked to choose an action for each possible decision OF THE OTHER COMPONENTS OF YOUR GROUP.

What does it means? Look here:

- Choice 1. Action toward someone who did not participate: A, B, or C? 
- Choice 2. Action toward someone who put 0 tokens in the common project: A, B, o C?

- Choice 3. Action toward someone who put 10 tokens in the common project: $\mathrm{A}, \mathrm{B}, \mathrm{o}$ C?

- Choice 4. Action toward someone who put 20 tokens in the common project: A, B, o C?

- Choice 5. Action toward someone who put 30 tokens in the common project: A, B, o C?

- Choice 6. Action toward someone who put 40 tokens in the common project: A, B, o C?

Every choice corresponds to the action you want to take in response to every decision possible of other members of the group.

YOU WILL NOT KNOW EXACTLY WHICH MEMBER OF THE GROUP WILL BE AFFECTED BY YOUR DECISIONS. One you made all the six choices the computer will select randomly a member of your group which will be affected by your Choice.

After having observed the results of the First Decision, you will be able to decide these actions.

Let's make an example

Suppose the computer chose to associate with you a member of the group that put 0 tokens in the common project. It will be this (anonymous) member that will affected by your action indicated in the six choices. Suppose you have indicated action $\mathrm{C}$ in Choice 2: this participant will see his reward reduced by 24 coins and in this case you will pay 8 tokens. Also, the computer will choose a participant who will decide an action toward you: the reasoning to do is the same. If you put 30 tokens and the participant decided $\mathrm{B}$ in Choice 4, you lose 12 tokens and the participant who decided B pays 4 tokens. In fact, the choice 4 , indicates the action that the participant wanted to implement toward a member of the group that had put 30, and you just put 30 . 


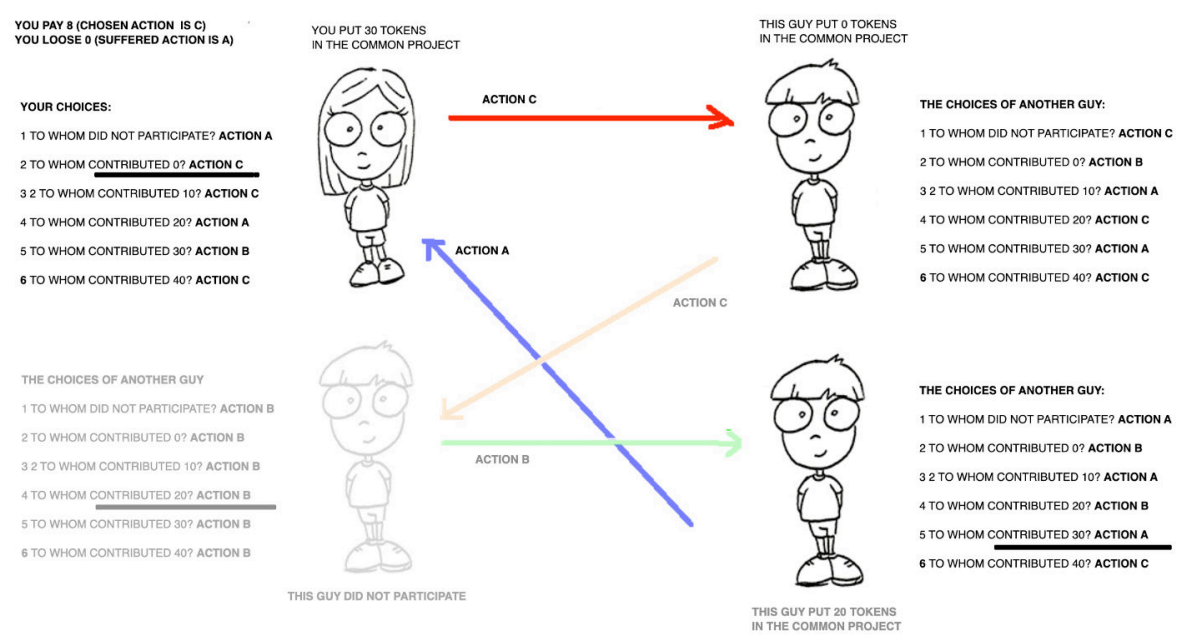

The instructions will remain available on the screen for the duration of this part of the study.

Do not hesitate to raise your hand if there are any questions. One of us will come to you to answer you.

In the next screen you will have to answer some questions that WILL NOT HAVE EFFECT on your final payment, but which are useful for you to verify that you have understood the instructions correctly.

Click on 'Next' to continue.

\section{Second Part - Training Questions}

Suppose that in the first decision you decided to put 40 tokens in the common project.

The other participants of the group put respectively 10, 20, 30 tokens. In total there will be 100 tokens in the common project, which become 200 after being multiplied by two.

In the second decision you made the following choices:

- Choice 1: Action A toward members of the group that put 0 in the common project, you decide to reduce their reward by 0 , paying 0 .

- Choice 2: Action A toward members of the group that put 10 in the common project, you decide to reduce their reward by 0 , paying 0 . 
- Choice 3: Action $\mathrm{C}$ toward members of the group that put 0 in the common project, you decide to reduce their reward by 24 , paying 8 .

- Choice 4: Action B toward members of the group that put 0 in the common project, you decide to reduce their reward by 12, paying 4 .

- Choice 5: Action $\mathrm{C}$ toward members of the group that put 0 in the common project, you decide to reduce their reward by 24 , paying 8 .

In total, how many tokens do you receive from the common project, before deciding how many tokens to remove to others?

- 25 tokens

- 50 tokens

- 100 tokens

If the computer select your choice of how many tokens to remove from another member of the group which put 40 tokens in the common project, how many tokens do you lose?

- 24 tokens

- 0 tokens

- 8 tokens

Which final reward do you receive if you decided to reduce of 24 tokens someone else reward?

- 40 from the project +40 in your bank account -8 that you spent to reduce the tokens of someone else.

- 50 from the project +0 in your bank account -8 that you spent to reduce the tokens of someone else. 
- 0 from the project +40 in your bank account -8 that you spent to reduce the tokens of someone else.

Click "Next" to continue.

\section{Second Part - Solution to the training questions}

Your answer to the question 'In total, how many tokens do you receive from the common project?' was: 50 tokens. This answer is correct.

Your answer to the question 'If the computer select your choice of how many tokens to remove from another member of the group which put 40 tokens in the common project, how many tokens do you lose?' was: 24 tokens This answer was wrong.

Your answer to the question 'Quale compenso finale ottieni, se hai scelto di togliere 24 gettoni ad un soggetto?was : 0 from the project +40 in your bank account -8 that you spent to reduce the tokens of someone else. This answer was wrong.

\section{Explanation:}

Solution to the first question: The sum of the tokens put in the common project by the members of your group (you included) was $40+10+20+30=100$. The tokens in the common project are multiplied by 2 , so the value of the common project will be equal to $100 \times 2=200$. These tokens are divided equally among the 4 members of the group, so each of them will obtain from the common project 200:4=50 tokens.

Solution to the second question: If you indicated the action $\mathrm{C}$ in correspondence to a member which decide to put 40 tokens in the common project, the member loses 24 tokens and you pay 8 tokens.

Solution to the third question: You have chosen the action $\mathrm{C}$, which correspond to reducing of 24 tokens the reward of another component of your group. Choosing C, you pay 8 tokens. You obtained 50 tokens from the common project, and you had no token in your private account after contributing all 40 of them. So you obtain 50 tokens from the common project +0 from your private account -8 that you spent to reduce the reward of another member of the group.

Is everything clear? To proceed click on "Next". 


\section{Second Part - First decision}

You can now decide to:

- Participate in this part of the game

- Do not participate and obtain 40 tokens (independently from the choice of the others).

What do you decide?

Do you want to participate?

- Yes

- No

Click on "Next" to continue

\section{Page 19 - Second Part - First Decision}

How many tokens do you put in the common project?

- 0 tokens

- 10 tokens

- 20 tokens

- 30 tokens

- 40 tokens

Click on "Next" once you made your choice.

\section{Second Part - Second Decision}

\section{Result of the first decision}

You put XX tokens in the common project. The other members of your group made the following choices:

- To participate putting XX 
- To participate putting XX

- Do not participate.

In synthesis $\mathrm{X}$ members of your group decided to participated (including you), putting in the common project as total of XX points. Thus, you obtain from the common project XX points. Your reward in this first decision is then XX points.

\section{Second decisions}

You now have to make the second decision. You can take into account the result of the first decision reported above. Remember that you have the following actions available for the 6 choices reported below:

- Action A: You pay 0 tokens and the other member of the group loses 0 tokens.

- Action B: You pay 4 tokens and the other member of the group loses 12 tokens.

- Action C: You pay 8 tokens and the other member of the group loses 24 tokens.

1. What action do you want to take with a participant who decided not to participate to the project?

- Action A

- Action B

- Action $\mathrm{C}$

2. What action do you want to take with a participant who put 0 tokens in the common project?

- Action A

- Action B

- Action C

3. What action do you want to take with a participant who put 10 tokens in the common project?

- Action A 
- Action B

- Action C

4. What action do you want to take with a participant who put 20 tokens in the common project?

- Action A

- Action B

- Action C

5. What action do you want to take with a participant who put 30 tokens in the common project?

- Action A

- Action B

- Action C

6. What action do you want to take with a participant who put 40 tokens in the common project?

- Action A

- Action B

- Action C

\section{Third Part - Instructions}

Now the computer will form NEW groups of 4 participants, randomly.

In this part of the study you have to take TWO decisions which will have effect on your final reward.

Click "Next" to continue 


\section{Third Part - First Decision - Instructions}

Instructions

As in the previous parts, you have 40 tokens available. You have to choose how many to keep in your private account and how many to put in the common project.

You can choose one of the following values: 0, 10, 20, 30, 40.

As in the previous parts, the tokens that you put in the common project are doubled and then divided equally among the 4 members of your group.

The tokens that you DON'T put in the common project remain in your private account. ATTENTION: In this part of the study you cannot choose not to participate.

\section{Third Part - Second Decision - Instructions}

In the second decision, you have to choose among three possible actions $\mathrm{A}, \mathrm{B}$ or $\mathrm{C}$, to associate to ache of the five choices reported below. The three actions $\mathrm{A}, \mathrm{B}$ and $\mathrm{C}$ correspond to:

- Action A: You pay 0 tokens and the other member of the group loses 0 tokens.

- Action B: You pay 4 tokens and the other member of the group loses 12 tokens.

- Action C: You pay 8 tokens and the other member of the group loses 24 tokens.

As before, you are asked to chose an action for each possible decision OF THE OTHER COMPONENTS FO YOUR GROUP, indicating the action for each possible choice of the others, as follows:

- Choice 1. Action toward an agent that put 0 tokens in the common project: $\mathrm{A}, \mathrm{B}$ or $\mathrm{C} ?$

- Choice 2. Action toward an agent that put 10 tokens in the common project: A, B or $\mathrm{C} ?$

- Choice 3. Action toward an agent that put 20 tokens in the common project: A, B or C? 
- Choice 4. Action toward an agent that put 30 tokens in the common project: A, B or $\mathrm{C} ?$

- Choice 5. Action toward an agent that put 40 tokens in the common project: A, B or $\mathrm{C}$ ?

Attention! The only difference with respect to the Second Decision of the Second Part of the study is that neighter you nor any other participant can choose NOT TO PARTICIPATE in the first decision, and thus it is not possible to choose an action toward and agent that DOES NOT PARTICIPATE to the common project.

Also in this case, YOU WILL NOT KNOW EXACTLY WHICH MEMBER OF YOUR GROUP WILL BE AFFECTED BY THE ACTIONS YOU CHOSE IN THE SECOND DECISION. Once made the five choices, the computer will select randomly a member of your group that will be affected by your actions.

You will decide your actions after having observed the results of the First Decision.

Is everything clear?

The instructions will remain available at the bottom of the screen for the whole duration of this part of the study.

Raise your hand if you have questions. One of us will come to you to answer your questions. Click on "Next", when you are ready to continue.

\section{Third Part - First Decision}

How many tokens do you put in the common project?

- 0 tokens

- 10 tokens

- 20 tokens

- 30 tokens

- 40 tokens

When you decided click on "Next". 


\section{Third Part - Second Decision}

Result of the first decision.

You put XX tokens in the common project.

The other members of your group put:

- XX tokens,

- XX tokens,

- XX tokens.

The sum of the tokens put in the common project is XX tokens. Thus, each member of the group obtained XX tokens.

Your reward for this first decision is then XX tokens.

Second Decision.

Now you have to make the second decision. You can take into account the result of the first decision reported above. Remember that you can choose among the following actions:

- Action A: You pay 0 tokens and the other component of the group loses 0 tokens.

- Action B: You pay 4 tokens and the other component of the group loses 12 tokens.

- Action C: You pay 8 tokens and the other component of the group loses 24 tokens.

1. Which action do you want to take toward a member of the group that put 0 tokens in the common project?

- Action A

- Action B

- Action C

2. Which action do you want to take toward a member of the group that put 10 tokens in the common project?

- Action A

- Action B 
- Action C

3. Which action do you want to take toward a member of the group that put 20 tokens in the common project?

- Action A

- Action B

- Action $\mathrm{C}$

4. Which action do you want to take toward a member of the group that put 30 tokens in the common project?

- Action A

- Action B

- Action C

5. Which action do you want to take toward a member of the group that put 40 tokens in the common project?

- Action A

- Action B

- Action $\mathrm{C}$

\section{Fourth Part - Instructions}

Now the computer will form NEW groups of 4 random participants.

\section{Page 27 - Fourth Part - Instructions}

\section{Instructions}

You have to choose one number between 0 and 100, with 0 and 100 included.

Differently from the previous parts, in this part there is a winner in each group.

Who is the winner

The winner is the participant who chooses the closest number to the average of the numbers chosen by the components of the group, multiplied by $2 / 3$. 
The winner obtains 50 tokens, while the other participants do not receive anything. In case of a tie the 50 tokens are divided equally among all winners.

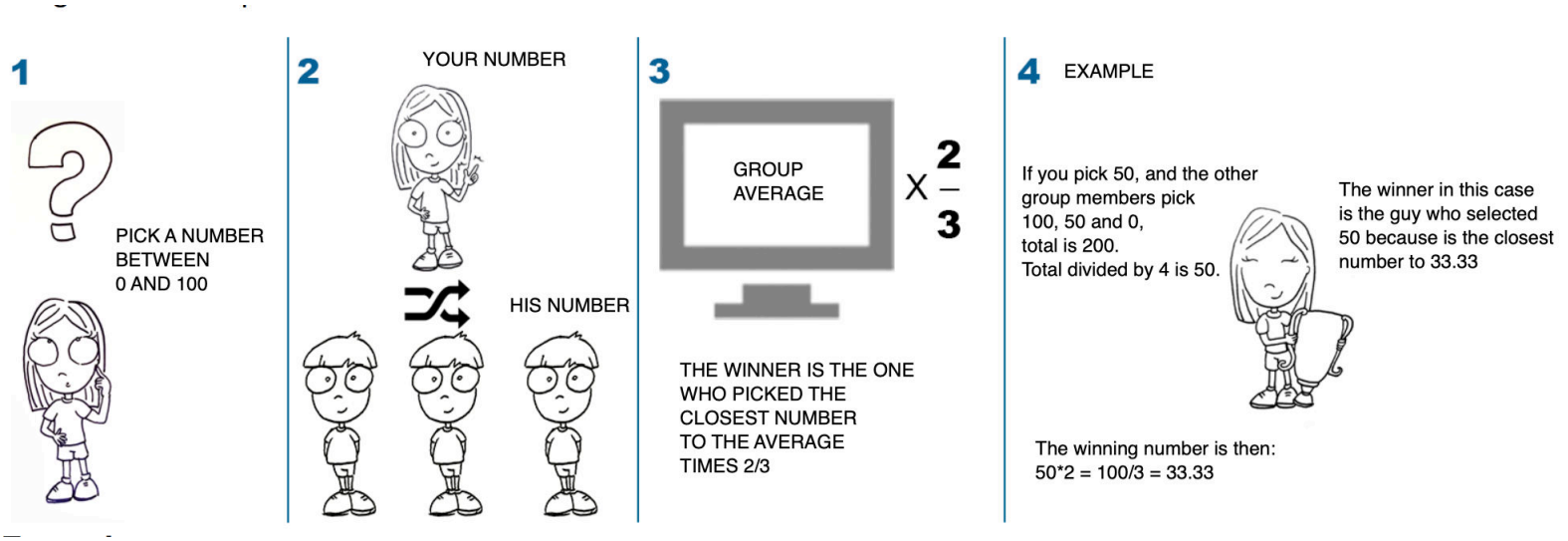

\section{Example}

Let us imagine that you choose 15, and that the other components of your group choose 25 , 58 e 12 . The total is: $15+25+58+12=110$. In order to obtain the average, we need to divide this sum by 4: so 110 divided by 4, we obtain 27,5 . Then, in order to obtain the winning number, we need to multiply by $2 / 3$ (so we multiply the average by 2 and divide it by 3 ); in our example the number to guess is then $27,5 \times 2=55$ and then $55: 3=18,3$ (the decimal numbers do not matter, so we say 18).

The winner is the person who guessed 15, as this is the closest number to 18 .

In this case then you win because you choose 15 and you obtain 50 tokens.

Is everything clear? Are there questions?

In the next page, you will answer two questions who do not have any effect on your final payoff, but that guarantee that you correctly understood the instructions. Click "next" when you are ready.

\section{Fourth Part - Training questions}

Imagine you have chosen the number 20 and the other participants to your group chose the numbers 10,20 e 70.

The average of all numbers is 30 . What is the number chosen by the winner?

The winner chose: FORM 


\section{What is your reward?}

Your reward is: FORM

\section{Fourth Part - Answer to the training question}

Your answer 'The winner chose 0' was wrong.

Your answer 'Your reward is: 0 tokens' was wrong.

Imagine you have chosen the number 20 and the other participants to your group chose the numbers 10, 20 e 70 . The average of all numbers is 30 . What is the number chosen by the winner? What is your reward?

Answer: The winner chose 20 and your reward is 25 .

Explanation: The average of all numbers chosen was $(20+10+20+70)=120: 4=30$ as indicated. The two third of 30 is equal to $30 x 2=60: 3=20$.

20 is the the closest number to 20 . So you and the other participant that chose 20 are the winners. Each of you receives 25 points.

Is everything clear?

Click "Next" when you are ready to proceed.

\section{Fourth part - Decision}

Please chose a number from 0 to 100: FORM

\section{Fourth part - A comment on your choice}

Now please, we ask you to write on the sheet of paper on the table a comment on your choice in this part of the study.

Did you apply a rule? If yes, could you describe shortly which one?

Click "Next" when you are ready to proceed. 


\section{Fifth part - Instructions}

Now the computer will form NEW groups of 4 participants, chosen randomly.

\section{Fifth part - Instructions}

\section{Instructions}

In this part of the study you find three choices that indicate possible numbers of tokens to assign to the four members of your group.

Note that the total number of tokens assigned to your group does not change for the three choices. Only the number of the tokens assigned to each component changes.

The possible choices are the following:

What do you have to do? You have to select the choice you prefer.

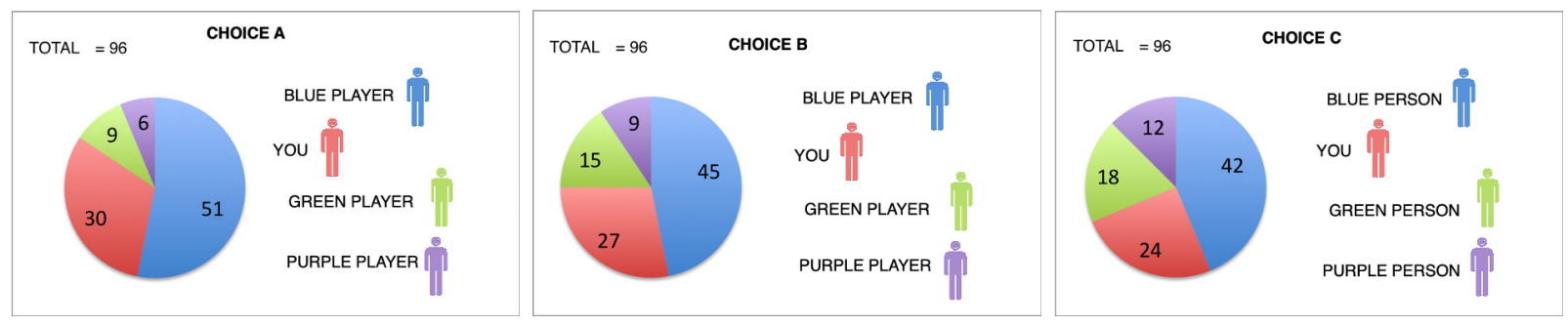

Figure S4

How is your reward computed?

After everybody has made its choice, the computer will randomly extract one of the members of your group, that decides the rewards of all members of the group.

- If for example you are extracted, your choices will determine the rewards for all members of your group.

The person extracted, in this case you, will get the reward indicated in RED with the label YOU, while the other components of the group will get a number of tokens equal to those indicated in the image, depending on the fact that they are extracted as BLUE, GREEN or VIOLET person.

For example, If you choose A and you are extracted to decide the rewards of all components 
of your group, you take 30 tokens, while the others obtain 51,9 and 6 tokens, depending on the fact that they are extracted by the computer as BLUE, GREEN or VIOLET person.

- For example, if you are NOT extracted, it will be the decision of another participant to determine your reward and the one of all other members of your group.

Your reward will correspond to the reward labelled BLUE, GREEN or VIOLET person, depending on the computer's extraction.

For example, if the person extracted by the computer to decide the rewards of all members

of the group indicated Choice C, that person obtains 24 tokens, if you have been extracted by the computer as VIOLET person you get 12 tokens, the other two members of the group obtain instead 18 and 42 tokens.

The instructions will remain available on the screen for the duration of this part of the study.

Do not hesitate to raise your hand and ask questions. One of us will come to you to answer them.

Before making your choice, we ask you to answer two questions that WILL NOT HAVE ANY EFFECT on your final reward, but that guarantee that you correctly understood the instructions.

Click "Next" when you are ready to proceed.

\section{Fifth part - Training Questions}

\section{(Figure S4 reproduced here)}

Imagine you have chosen Choice $B$.

If you are selected by the computer to decide the rewards of everybody your reward is:

1. 15 tokens

2. 27 tokens 
Imagine you have chosen Choice $A$.

If another member of your group is extracted to decide the rewards of all members of the group and that person has chosen Choice $C$. In this case your reward is:

1. 42 or 18 or 12 tokens, according to the random extraction of the computer.

2. 45 or 15 or 9 tokens, according to the random extraction of the computer.

\section{Fifth part - Answer to the Training Questions}

(Figure S4 reproduced here)

Your answer 'You have chosen B. If your are selected by the computer to decide the rewards of everybody your reward is: 15 tokens' was wrong.

Your answer 'If another component of your group is extracted to decide the rewards of everybody and this person chooses $C$, in this case your reward is: 42 or 18 or 12 tokens, according to the random extraction of the computer' was correct.

Answer to the first question: If you are chosen by the computer to decide the rewards of all members of your group and you choose B, then you will obtain the reward indicated in RED with the label YOU, thus 27 tokens. The other three components will obtain respectively 45, 15 and 9 tokens, depending on them being extracted as the BLUE, GREEN or VIOLET person.

Answer to the second question: On the contrary, if the computer extracts another component of your group to decide the rewards of all members of the group, and this component has chosen $\mathrm{C}$, you can obtain 42, 18 or 12 tokens, depending on the fact that you are extracted as the BLUE, GREEN or VIOLET person.

\section{Fifth part - Decision}

(Figure S4 reproduced here)

Now you can take your decision:

1. Choice A 
2. Choice B

3. Choice $\mathrm{C}$

\section{Fifth part - A comment on your choice}

Now please, we ask you to write on the sheet of paper on the table a comment on your choice in this part of the study.

Did you apply a rule? If yes, could you describe shortly which one?

Click "Next" when you are ready to proceed.

\section{Your results}

Thanks for participating to this study, in the following you can find your results.

\section{FIRST PART RESULTS}

For what concerns the this decision, you started this part of the study with 40 tokens. You decided to contribute 30 tokens. Your group contributed a total of XX tokens. Thus the individual reward for the participation in the common project is XX tokens. The reward you obtain for this decision is then XX tokens.

Your reward for this Part is then XX tokens.

For this part you will be paid: $\mathrm{X} . \mathrm{XX} €$

\section{SECOND PART RESULTS}

You had XX tokens available and you decided to put XX tokens in the common project. Your group has put in the common project an overall amount of XXX tokens, so the individual reward was XX tokens.

Given your choice, another participant decided to reduce your reward by XX tokens. Your action toward another participant costed you X tokens.

Your reward for this part is then XX tokens.

For this part of the study your reward is : $\mathrm{X}$.XX $€$ 


\section{THIRD PART RESULTS}

You had 40 tokens available in your private account and you decided to participate in this part of the study.

You contributed XX tokens.

$\mathrm{X}$ members of your group decided to participate (including you). Your group contributed a total of XX tokens. Your reward from the common project is then XX tokens.

Given your choice one of the other players decided to reduce your reward by XX tokens.

Beside, your action toward another participant costed X token.

Thus, your reward for this part of the study is then XX tokens.

For this part of the study you will be paid X.XX $€$

\section{FOURTH PART RESULTS}

You have chosen $\mathrm{X}$ [Xs represent the numerical information presented to the participant]. The others have chosen $\mathrm{X}, \mathrm{X}$ and $\mathrm{X}$. The two third of the mean was $\mathrm{X}$ and the closest number was $\mathrm{X}$. There are $\mathrm{X}$ participants that have chosen this number and you are one of them. Consequently, you receive $\mathrm{X}$ tokens.

For this part of the game you will be paid: $\mathrm{X}, \mathrm{XX} €$

\section{FIFTH PART RESULTS}

You have chosen X.

Someone else has been selected as Person 2.

You have been selected as Person 1.

Thus, your reward for this part is XX tokens.

For this part of the game you will be paid: $\mathrm{X}, \mathrm{XX} €$

\section{PARTICIPATION REWARD}

As reward for your participation, you will further receive a fix amount of: $€ 5.00$ THE TOTAL REWARD THAT WILL BE PAID TO YOU IS: €XX,XX

\section{BEFORE LEAVING:}


Thank you for your availability. We ask you a last effort and patience while we prepare the payments of the rewards. While you are waiting, we ask you to answer to a short questionnaire. The information provided, as well as the results of the whole study, will be managed with the upmost respect for your privacy and used solely for scientific purposes.

\section{S3.1 Survey}

\section{Questionnaire 1 - Clarity of the study}

Thank you very much again for the participation to this study. As this experience draws to an end we would like to ask you a few questions:

Were the instructions of the todays' study clear?

1. Absolutely not clear

2. Not very clear

3. Quite Clear

4. Very Clear

This study has been realized with the support of tablets such as the one you keep in your hands. We would like your opinion on the easiness of using this tablet from your point of view. We ask you to indicate the answer on a scale where 1 corresponds to "Absolutely difficult to use" and 10 corresponds to "Absolutely easy to use". (Radio Button Answer from 1 to 10).

1. Absolutely difficult to use

10. Absolutely easy to use

We would like to have your opinion on the software interface used for this study. We ask you to indicate the answer on a scale where 1 corresponds to "Absolutely difficult to use" and 10 corresponds to "Absolutely easy to use". (Radio Button Answer from 1 to 10).

1. Absolutely difficult to use ...

10. Absolutely easy to use 
Questionnaire 2 - Citizenship, Age and sex

What is your country of citizenship? Choice from drop down list

Age? Form

Sex Male or Female

Questionnaire 3 - Questionnaire

Please indicate your birthplace:

1. In this city or in the neighbouring municipalities.

2. Within the province but outside this city or the neighbouring municipalities

3-23. List of Italian regions

24. Abroad

Please indicate the birthplace of YOUR MOTHER:

\{Same possible answers that in the question about own birthplace

Please indicate the birthplace of YOUR FATHER:

\{Same possible answers that in the question about own birthplace

Where you were going at Elementary School?

\{Same possible answers that in the question about own birthplace

Questionnaire 4 - Earthquake 2012

When the earthquakes of the May-June 2012 struck, were you living in the area hit by the earthquake?

1. No

2. Yes 


\section{Was your main house damaged as consequence of the earthquake?}

1. No, No damages

2. A - Immediately accessible

3. B - temporarily unfit for use, but accessible with measures small interventions

4. C - partially unfit for use

5. D - temporarily unfit for use, to be checked by a specialist.

6. E- unfit for use

7. $\mathrm{F}$ - unfit for use for external risks ${ }^{3}$

\section{Today, your main house is:}

1. Fit for use

2. Being fixed.

3. Not yet fixed.

\section{In the emergency period, after the earthquake:}

1. I kept living in my house 2. I moved in another house within the area hit by the earthquake

3. I used the temporary structures provided by the civil protection

4. I move temporarily my residence outside the area hit by the earthquake

5. I move permanently my residence outside the area hit by the earthquake

\section{Questionnaire 5 - Family}

\section{Marital status:}

1.Unmarried

2.Married

3.Separated

4.Divorced

5.Widower

\footnotetext{
${ }^{3}$ The classification in the points A to $\mathrm{F}$ refer to the official civil protection classification. Each house in the area struck by the earthquake was classified by structural engineers and the result communicated to families, which are thus well informed about the classification system.
} 
How many people compose your family, including yourself?

1.1

2.2

3.3

4.4

5.5 or more

Are you the family's main source of income?

1.Yes

2.No

Do you have (or had) brothers and/or sisters?

1.No

2.1

3.2

4.3 or more

Questionnaire 6 - House and Automobiles

Does your family own a car?

1.Yes, 1

2.Yes, 2 or more

3.No

Is the house where your family lives:

1.Rented

2. Your property

3.Other

Questionnaire 7 - Employment

What is your Employment status:

1.Employee 
2.Self-employed

3.Unemployed searching for job

4.Student

5.Retired

6.Unoccupied (unable to work or not searching a job)

\section{Questionnaire 8 - Taking profit}

Do you think that most people would try to take advantage of you if they got a chance, or would they try to be fair? Please choose one answer in the scale from one to 10, where 1 means that "people would try to take advantage of you", and 10 means that "people would try to be fair":

1.People would try to take advantage of you

10. People would try to be fair

\section{Questionnaire 9 - Trust in institutions}

I am going to name a number of organizations. For each one, could you tell how much confidence you have in them: is it a great deal of confidence, quite a lot of confidence, not very much confidence or none at all?(one answer for each):

1.Associations or groups related to the churches

2.Sport or leisure associations or organizations

3.Artistic, music or educational associations or organizations

4.Labor Unions

5.Political Parties

6.Environmental organizations

7.Professional organizations

8. Charitable or humanitarian organizations

9.Consumers organizations

10. European Union 


\section{Questionnaire 10 - Elections, referendum and blood donations}

Have you made a blood donation in the last 12 months?

1.Yes

2.No

3.I cannot donate for medical reasons

Did you vote in the last European elections in 2014?

1.Yes

2.No

3.I had no voting right

Did you vote in the last referendum of 2014 ?

1.Yes

2.No

3.I had no voting right

Questionnaire 10 - Studied and Worked abroad

Have you ever studied in a school or university abroad? (One of the following answers)

Have you ever worked abroad with an independent activity or had been a employee of a foreign company abroad? (One of the following answers)

1. No

2. Yes, for less than 3 months

3. Yes, for a period between 3 and 12 months

4. Yes, for a period between 12 and 36 months

5. Yes, for a period of more than 36 months 


\section{S3.2 Cognitive Reflection Test}

1. If you flipped a fair coin three times, what is the probability that it would land "Heads" at least once?... percent

2. A bat and a ball cost $\$ 1.10$ in total. The bat costs $\$ 1.00$ more than the ball. How much does the ball cost? ... cents

3. If it takes 5 minutes for five machines to make five widgets, how long would it take for 100 machines to make 100 widgets? ... minutes

4. In a lake, there is a patch of lily pads. Every day, the patch doubles in size. If it takes 48 days for the patch to cover the entire lake, how long would it take for the patch to cover half of the lake?... days

5. If three elves can wrap three toys in hour, how many elves are needed to wrap six toys in 2 hours? ... elves

6. Ellen and Kim are running around a track. They run equally fast but Ellen started later. When Ellen has run 5 laps, Kim has run 15 laps. When Ellen has run 30 laps, how many has Kim run? ... laps

7. Jerry received both the 15 th highest and the 15 th lowest mark in the class. How many students are there in the class?... students

8. In an athletics team, tall members are three times more likely to win a medal than short members. This year the team has won 60 medals so far. How many of these have been won by short athletes?... medals

\section{S3.3 Final Summary}

Thanks for having participated to this study.

The study is now finished, your results for each part of the study as well as the total amount of money that you will receive are summarized below:

REWARD FOR THE FIRST PART $€ X, X X$

REWARD FOR THE SECOND PART $€ \mathrm{X}, \mathrm{XX}$

REWARD FOR THE THIRD PART $€ X, X X$

REWARD FOR THE FOURTH PART $€ X, X X$ 


\section{REWARD FOR THE FIFTH PART €X,XX}

REWARD FOR PARTICIPATION $€ 5.00$

THE TOTAL THAT WILL BE PAID TO YOU IS: €XX,XX

You are now at the end of this study,

Please remain seated until your number is called.

Your unique identifier is: $\mathrm{XXXXXX}$ 
S3.4 Instructions in Italian 


\section{Utilizzo del Tablet}

Questa pagina ha il solo scopo di aiutarti a comprendere come funziona il dispositivo che stai utilizzando.

Lo schermo del dispositivo che ti trovi davanti è sensibile al tocco delle dita.

\section{Scorrere la pagina.}

Dal momento che alcune pagine contengono più testo di quello che è possibile visualizzare a video, è necessario scorrere la pagina.

Se appoggi un dito sullo schermo del dispositivo e provi a muoverlo verticalmente, la pagina scorrerà di conseguenza.

Prenditi qualche minuto per familiarizzare con questo meccanismo se non lo conosci bene. II testo nel riquadro giallo di seguito è inutile e serve solo per farti familiarizzare con il processo di scorrimento delle pagine su questo dispositivo.

Quando sei pronto per le prossime istruzioni, scorri in basso al di sotto del testo nel riquadro giallo.

Lorem ipsum dolor sit amet, consectetur adipiscing elit. Donec vestibulum vehicula ligula sit amet dapibus. Phasellus in porttitor lacus. Praesent euismod ornare nunc ullamcorper interdum. Nullam non odio cursus, aliquam quam eu, dignissim enim. Suspendisse potenti. Maecenas pulvinar dui luctus, ultricies augue eu, consequat ante. Nulla facilisi. Cras porta porta efficitur. Integer aliquet tortor id quam dignissim volutpat. Pellentesque porta feugiat metus vitae molestie. Cras faucibus id erat ac facilisis. Integer magna massa, lacinia non elementum sit amet, viverra ornare neque. Etiam accumsan justo sit amet dolor commodo hendrerit. Nunc ex lorem, venenatis in dignissim quis, consequat at tortor. Cras lacinia tincidunt ipsum, vitae cursus lectus cursus id. Sed vel velit viverra, pulvinar velit a, semper dui. Integer dignissim fermentum libero, vitae eleifend purus. Nullam interdum mollis fringilla. Quisque tempor nunc vitae magna pellentesque fringilla quis eget massa. Aliquam imperdiet purus eu gravida sodales. Proin pulvinar felis vitae arcu posuere aliquet. Nam et auctor libero. Nunc id metus arcu. Quisque non suscipit justo. Nunc venenatis quam faucibus auctor facilisis. Maecenas eu placerat lacus, ut pretium neque. Phasellus efficitur ante efficitur libero ultrices gravida. Cras eu turpis quis nibh faucibus efficitur. Curabitur in fermentum erat. In hac habitasse platea dictumst. Integer accumsan libero nec pulvinar luctus. Aenean eget tellus suscipit, malesuada erat eget, pretium turpis. Donec egestas massa nec ante lacinia, sed tempor velit semper.

Donec sodales, diam id commodo bibendum, nisi sapien pharetra magna, sit amet euismod lectus velit a dui. Quisque sagittis interdum sem vitae aliquam. Donec vitae convallis leo. Maecenas sodales, mauris a interdum elementum, lacus purus tristique ligula, quis aliquam ante lacus quis lacus. Aliquam erat volutpat. Aliquam nec erat sed lectus sollicitudin finibus. Sed sit amet $n$ Ut ut auctor lectus. Lorem ipsum dolor sit amet, consectetur a convallis a egestas id, pulvinar ut neque. Proin a orci nec leo augue luctus commodo eu et ipsum. Aenean cursus, orci nec eros, at scelerisque metus massa sit amet purus. Proin finibus 
felis sollicitudin diam blandit vehicula. Morbi at massa libero. Ut bibendum non arcu vitae auctor. Pellentesque lacinia mauris arcu, at lacinia urna tincidunt eu. Nunc consequat aliquet luctus. Fusce pretium sodales venenatis. Nam ut blandit felis. Vivamus ultricies ex nec blandit viverra. Vestibulum sed tempus mauris. Proin id orci quis ex pulvinar lacinia quis quis leo. Vivamus pretium tortor massa, vitae feugiat nulla bibendum sit amet. Phasellus nec urna mauris. Mauris et viverra orci. Pellentesque habitant morbi tristique senectus et netus et malesuada fames ac turpis egestas. Sed volutpat tortor id velit aliquet consequat. Mauris massa purus, convallis et augue vitae, tristique finibus libero. Vestibulum congue nibh vel tincidunt fermentum. Pellentesque ut congue erat. Nam rutrum metus vel semper auctor. Integer finibus tortor sem, eu vehicula justo fringilla vitae. Suspendisse ultricies felis augue, sodales ornare nulla convallis sit amet. Curabitur varius est eu lacus malesuada mollis. Maecenas eu finibus neque. Nullam euismod varius volutpat.

Ut velit urna, efficitur nec malesuada ac, dignissim ut justo. Maecenas a sapien tellus. Curabitur ipsum leo, consequat porta pellentesque et, vehicula eu ipsum. In molestie varius molestie. Nunc ullamcorper lorem sit amet dui commodo fermentum. Duis ornare porttitor mi eu consectetur. Donec vulputate ac ligula non venenatis. Mauris quam nunc, tristique rutrum volutpat vel, dignissim in arcu. Praesent tempor velit nec felis feugiat, ac ultrices arcu efficitur. Phasellus porttitor sem vitae justo gravida ultricies. Suspendisse ut sagittis justo, nec luctus purus. Aliquam nec maximus ex. Aenean id libero nisl. Cras sapien ipsum, rhoncus vitae quam eu, scelerisque faucibus est. Etiam pharetra ligula lectus, posuere fermentum nisl vehicula quis. Proin risus odio, posuere sed semper vel, tempus nec diam. Nunc pretium est vitae scelerisque pretium. Phasellus diam dolor, elementum sed mauris et, ultricies suscipit velit. Vestibulum ac diam massa. Morbi a scelerisque dolor. Ut maximus risus sit amet lorem vehicula, vitae tempus arcu tincidunt. Vestibulum eleifend sed mi vitae pellentesque. Fusce quis cursus augue. Fusce facilisis erat est, vitae dapibus neque ullamcorper id. Nullam et finibus mauris. Nullam ipsum tortor, interdum vel lectus vel, vehicula tempor purus. Morbi cursus ornare purus, dignissim pulvinar purus mattis eget. Morbi semper tortor at massa scelerisque dictum. Praesent pulvinar massa purus, non malesuada nulla porttitor eget. Aliquam vitae erat ac neque facilisis rutrum ut in ipsum. Nunc in volutpat risus, id efficitur tellus. Sed eget ex a erat tincidunt efficitur sed vel lorem. Vivamus tincidunt sollicitudin dui in pharetra. Vivamus ac diam ornare, rutrum nulla quis, tincidunt sem. Suspendisse efficitur, nisi ac finibus eleifend, nisi massa varius eros, ut posuere orci lacus ac nisi. Morbi fringilla ipsum eu placerat congue. Fusce a gravida sapien. Aliquam erat volutpat. Sed vitae dapibus nisl. Vivamus feugiat nunc sed nibh elementum blandit.

Suspendisse eu finibus leo. Mauris placerat lectus vitae consequat posuere. Mauris dignissim orci at odio tempor, eu commodo dui commodo. Interdum et malesuada fames ac ante ipsum primis in faucibus. Etiam elit odio, ultrices id turpis ac, tincidunt condimentum nisi. Suspendisse ultricies aliquet rhoncus. Phasellus ultricies aliquet nisl, auctor tristique tortor rhoncus ac. Fusce euismod venenatis turpis, ut aliquam leo volutpat et. Nunc eget magna dolor. Nam pharetra venenatis libero eu consectetur. Suspendisse feugiat a lorem non hendrerit. Donec ornare rhoncus massa consequat lobortis. Donec hendrerit libero id semper pharetra. Pellentesque blandit neque non ornare efficitur. Pellentesque pellentesque suscipit consectetur. Cras lobortis sodales leo, id gravida magna blandit eget. Suspendisse interdum odio sed ultricies venenatis. Vestibulum ante ipsum primis in faucibus orci luctus et ultrices posuere cubilia Curae; Aliquam at eros et nulla rhoncus porttitor vitae eu dolor. Aliquam maximus risus lacus, eget maximus tellus commodo id. Morbi sagittis ultricies scelerisque. Maecenas eros justo, gravida id risus vel, gravida malesuada tellus. Duis eget lorem a tellus placerat consectetur. Pellentesque eget massa felis. Nunc ultricies, arcu vel lacinia consequat, nisi nisi venenatis lacus, sit amet ultrices lorem purus a mauris. Nullam accumsan justo mi, in commodo enim tempor id. Etiam ut vehicula sem, sit amet tincidunt magna. Vestibulum vel velit vehicula, consequat nisi eu, finibus purus. In egestas ornare risus vitae interdum. Sed 
tristique ultrices est a fermentum. Nam eu libero fermentum, commodo massa ac, bibendum purus. Integer nec eros tellus. Morbi id elit ac dui consectetur dictum sit amet non velit. Aenean feugiat laoreet gravida. Aliquam diam enim, sollicitudin ac lorem a, iaculis porta tellus. In vehicula quam non massa accumsan, vitae feugiat nibh maximus. Pellentesque efficitur dolor ac ultricies scelerisque. Nunc rhoncus eleifend leo in congue. Integer luctus in sem et luctus. Nulla facilisi. Maecenas volutpat eleifend nibh vitae ornare. In vel libero fringilla, sollicitudin orci a, gravida sem. Duis vulputate nunc quis sollicitudin elementum. Nulla tincidunt vehicula porttitor. Donec quis augue a magna mattis interdum nec vel tortor. Curabitur vitae ante gravida, scelerisque orci quis, fermentum nibh. Sed rhoncus viverra ex vitae congue. Mauris sit amet faucibus dui. Vestibulum tristique justo pellentesque felis congue, nec rutrum mauris convallis. Sed venenatis tellus viverra dolor auctor mollis. Curabitur rutrum tincidunt vehicula. Suspendisse sed scelerisque orci. Sed sagittis, odio mollis mattis placerat, est risus tempor lectus, vitae pulvinar urna turpis id turpis. Pellentesque eleifend rhoncus neque. Donec ornare semper aliquam. Suspendisse et dapibus urna, in vehicula libero. Nulla ac urna est. Donec porttitor neque et posuere facilisis. Phasellus in quam quis dolor consequat ultrices. Mauris sit amet viverra quam. Mauris luctus nisi at feugiat iaculis. Vivamus posuere sed nunc vel semper. Nam eu pellentesque nibh. Proin ultrices imperdiet augue, vitae varius risus tincidunt eget. Etiam ullamcorper ipsum dapibus porta ornare. Ut interdum libero eu diam aliquet ullamcorper. Pellentesque porta vestibulum arcu sit amet tincidunt. Curabitur ultrices, erat ut porta mattis, urna tortor euismod eros, a ultrices orci lacus sed eros. Suspendisse vel ligula ultrices, pretium nisl ac, euismod purus. Curabitur elit libero, scelerisque ut gravida vitae, finibus at erat. Cras pellentesque risus non pellentesque finibus. In porttitor, metus sit amet viverra dictum, arcu diam dictum orci, sit amet mollis nulla dui sed erat. Nam semper ultrices metus, sed pharetra ante aliquet non. Quisque malesuada lobortis eros et interdum. Duis luctus id sem at sodales. Donec in rutrum dui, eu tristique enim. Suspendisse vel orci sit amet felis tempor vulputate vel vel mi. Sed tristique nibh eget metus volutpat, quis aliquam ligula consectetur. Proin lectus turpis, hendrerit et finibus vel, aliquet vel tellus. Mauris eu rhoncus arcu. Nullam egestas nisl ut augue dignissim, ut sollicitudin tortor finibus. Cras tristique risus magna, eget semper justo vestibulum a.

Nam id rhoncus metus. Pellentesque at nunc vel lectus condimentum viverra ut sit amet eros. Phasellus in dui mattis, euismod lorem sit amet, maximus orci. In sollicitudin arcu vel scelerisque fringilla. Aenean varius ut dui at pretium. Fusce ornare urna lacus, vitae euismod sem tempor id. Ut volutpat felis vel commodo egestas. Nullam et tincidunt ante, eget euismod velit. Suspendisse condimentum felis sit amet arcu semper laoreet. Quisque varius nulla id tellus maximus commodo. Mauris sit amet ex rhoncus, placerat magna nec, pellentesque eros. Nulla molestie sed orci id eleifend. Morbi vestibulum metus ut nulla laoreet, at auctor tortor bibendum. Etiam volutpat congue tortor, ac consequat ligula pellentesque vitae.

Suspendisse at risus eget turpis porta suscipit. Donec a quam velit. Sed sagittis eros enim, a porta tortor maximus sit amet. Nulla id quam ut orci eleifend tempus. Praesent convallis volutpat elit, gravida eleifend elit pharetra sodales. Interdum et malesuada fames ac ante ipsum primis in faucibus. Morbi venenatis purus leo, vitae tempor enim venenatis eu. Suspendisse quis lorem eget lectus iaculis luctus. Nam nec lacinia felis. Duis vestibulum nisl tempus, bibendum nunc at, venenatis ante. Praesent sollicitudin sodales feugiat. Donec mattis mi quis turpis bibendum interdum. Donec suscipit dui sit amet arcu cursus, sed egestas tortor condimentum. Integer aliquet lorem felis, finibus ornare enim ornare vitae. Curabitur varius velit ut massa condimentum, a eleifend dui molestie. Vivamus eu est at mauris efficitur pretium. Aenean nisi est, malesuada id sodales sodales, lacinia in orci. Ut nec urna tristique, pharetra tellus in, iaculis lorem. Proin venenatis nibh ac dui luctus, at interdum massa dapibus. Ut aliquam nulla at arcu ullamcorper, eu condimentum ipsum ultricies. Duis sed mi non ligula faucibus tristique at vitae odio. Vestibulum facilisis dapibus erat. Praesent commodo ipsum ac lacus ornare, quis consequat nunc rutrum. Curabitur ante 
tortor, tristique sed pharetra vel, placerat vel magna. Sed pharetra rutrum orci nec facilisis. Nullam fringilla eros tincidunt libero laoreet feugiat. Cum sociis natoque penatibus et magnis dis parturient montes, nascetur ridiculus mus. Fusce porttitor risus tellus, in iaculis urna dictum et. Phasellus hendrerit ut mauris eu vestibulum. Phasellus hendrerit tellus magna, et ornare ligula consequat ac. Cras ut risus ut quam volutpat dictum ac eget diam. Integer ullamcorper efficitur rhoncus. Quisque ultrices, elit nec faucibus semper, sapien eros facilisis ipsum, a congue mauris purus in risus. Aenean ornare nisi et consectetur placerat. Donec eget metus ultrices, facilisis dui vel, pharetra justo. Nulla facilisi. Nulla ut mattis tortor. Donec at venenatis lorem. Etiam at urna et ex feugiat accumsan. Cras volutpat id sapien non tincidunt.

Oltre a leggere le istruzioni (riportate in riquadri gialli simili a quello qui sopra), questo studio richiede 2 tipi di attività:

Nel primo ti vengono poste domande che richiedono l'inserimento di un numero. Cliccando sul riquadro vuoto vicino alla domanda, ti apparirà una tastiera numerica. Attraverso essa puoi inserire numeri.

Per verificare di aver capito inserisci ora il numero 42 come risposta alla seguente domanda:

Cosa viene dopo il numero 41 ?

L'ultimo tipo di attività richiesta per completare questo studio è la selezione di UNA risposta tra più risposte possibili. In tutte le domande in questo formato puoi scegliere una sola opzione alla volta, cliccando con la punta di un dito su una delle risposte. Puoi scegliere qualunque risposta disponibile, e puoi cambiare la tua risposta quante volte vuoi, semplicemente cliccando sulla nuova risposta.

Prenditi qualche minuto per provare a selezionare le risposte e, quando sei certo di aver capito, seleziona la seconda risposta per mostrare di aver compreso il funzionamento.

Questo è un esempio di domanda a scelta multipla. Seleziona la seconda risposta.

Questa non è la risposta giusta

Clicca su questa risposta per confermare che hai capito

risposta non corretta

risposta altresi non corretta

risposta sbagliata

Infine, lo studio è costituito di una serie di pagine in successione. Puoi modificare le tue risposte quante volte vuoi, e una volta terminata la tua scelta per quella pagina devi cliccare sul bottone "Successivo" per continuare.

Una volta cliccato su "successivo" non è in alcun modo possibile tornare indietro e cambiare le proprie scelte.

Quando sei pronto e ti senti sicuro nell'utilizzo di questo dispositivo, clicca su "successivo" per cominciare lo studio vero e proprio.

Successivo 


\section{Benvenuto!}

Ti ringraziamo innanzitutto per la tua partecipazione a questo studio che è organizzato dall'Università di Modena e Reggio Emilia in collaborazione con I'Università di Macerata.

Ti informiamo che alla fine dello studio avrai come rimborso per la tua partecipazione 5 euro ed un ulteriore compenso che dipenderà delle scelte che effettuerai sia tu che gli altri partecipanti presenti in questa sala. Riceverai il compenso al termine dello studio, in privato.

Ti chiediamo gentilmente di spegnere il telefono cellulare. Da questo momento in poi non è consentita alcuna forma di comunicazione tra $\mathrm{i}$ partecipanti presenti nella stanza e non è consentita comunicazione con l'esterno.

Se hai dei dubbi o delle domande da fare, in qualsiasi momento durante lo svolgimento dello studio, non esitare ad alzare la mano ed uno di noi verrà da te per chiarire qualsiasi dubbio.

E' molto importante seguire attentamente le istruzioni. Useremo, durante le istruzioni, degli esempi numerici che servono per illustrare più chiaramente le scelte da compiere. Tali esempi sono irrilevanti per il tuo compenso finale.

Lo studio è composto di 5 parti. In ognuna delle 5 parti, tu farai parte di un gruppo. Oltre a te, il gruppo sarà composto da altre tre persone. La composizione del gruppo è anonima. Tu non sarai mai in grado di sapere chi fa parte del tuo gruppo così come gli altri non sapranno chi è nel loro gruppo. La composizione del gruppo cambierà in ogni parte dello studio: ogni volta il computer farà una estrazione casuale e costituirà il nuovo gruppo di cui tu farai parte.

Durante lo studio ti verrà richiesto di prendere delle decisioni. Ogni decisione può essere cambiata quante volte si vuole, prima di premere sul pulsante "Successivo" in fondo alla pagina. Dopo aver cliccato sul pulsante "Successivo", I'ultima decisione selezionata diventa definitiva.

Da questo punto in poi il tuo guadagno sarà espresso in gettoni/punti. Ogni gettone/punto vale 0,04 euro.

Clicca sul bottone "Successivo" quando sei pronto per iniziare.

Successivo 


\section{Prima Parte - Istruzioni}

In questa parte dello studio devi prendere decisioni che avranno un effetto sul tuo compenso finale che dipenderà dalla tua scelta e da quella effettuata dai membri del tuo gruppo.

Ora il computer formerà in maniera casuale e anonima, gruppi di 4 partecipanti, di cui anche tu farai parte.

Clicca su Successivo per continuare.

Successivo 


\section{Prima parte - Istruzioni}

\section{Istruzioni}

Hai a disposizione 40 gettoni. Devi scegliere quanti di questi gettoni tenere nel tuo conto privato e quanti

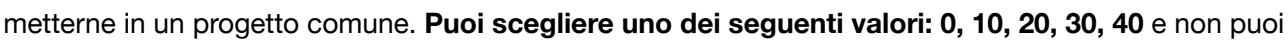
scegliere valori intermedi tipo 15, 23, 39.

Devi decidere quanti gettoni del tuo conto privato mettere nel progetto comune

Conto Privato
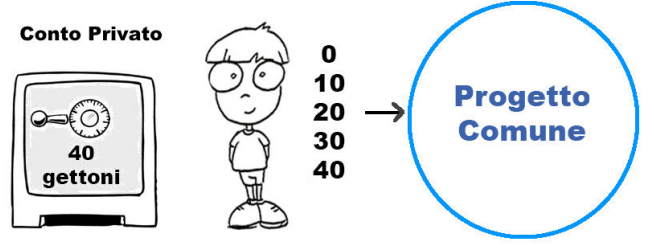

Attenzione! Puoi scegliere solo uno di questi valori: $\mathbf{0}, \mathbf{1 0}, \mathbf{2 0}, \mathbf{3 0}, 40$.

I gettoni che non metti nel progetto comune, restano nel tuo conto privato. I gettoni che metti nel progetto comune vengono raddoppiati e poi successivamente divisi equamente tra i 4 membri del gruppo, indipendentemente dal numero di gettoni che ognuno ha messo nel progetto comune.

FACCIAMO QUALCHE ESEMPIO.

Esempio 1: Se tutti i componenti del tuo gruppo mettono tutti i loro 40 gettoni nel progetto comune, il compenso di tutti raddoppierà: tutti otterrete 80 gettoni. Questo perché se tutti i membri del tuo gruppo mettono 40 gettoni nel progetto comune, il valore del progetto comune diventa $40+40+40+40=160$ gettoni.

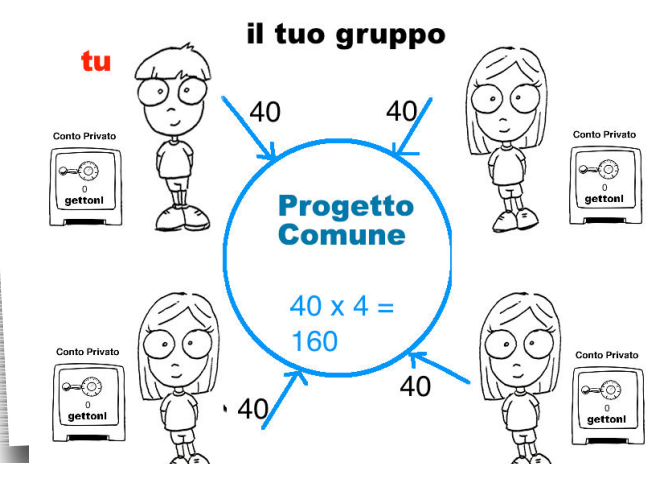




$$
\text { un a du }
$$

I 160 gettoni messi nel progetto comune vengono moltiplicati per 2 e divisi equamente tra i quattro partecipanti, $320 / 4=80$ gettoni ciascuno.

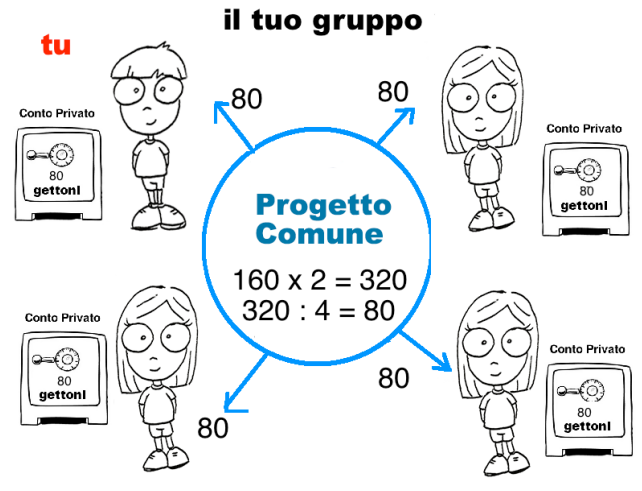

Esempio 2: Se tutti i membri del tuo gruppo invece mettono i loro 40 gettoni iniziali, mentre tu tieni per te i tuoi 40 , nel tuo conto privato resteranno i 40 gettoni che non hai messo nel progetto comune.

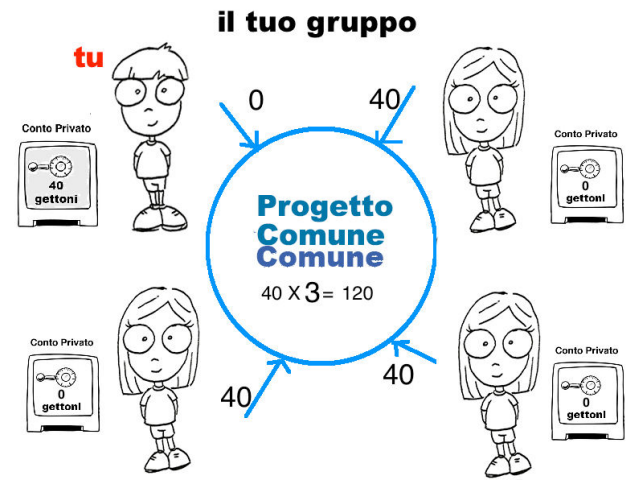

II valore totale del progetto comune sarà $40 \times 3=120$ che verrà moltiplicato per 2 . II valore finale sarà ora 240 gettoni, che sarà diviso tra i quattro componenti del gruppo, tu incluso. Quindi $240: 4=60$. Ognuno otterrà dal progetto comune 60 gettoni.

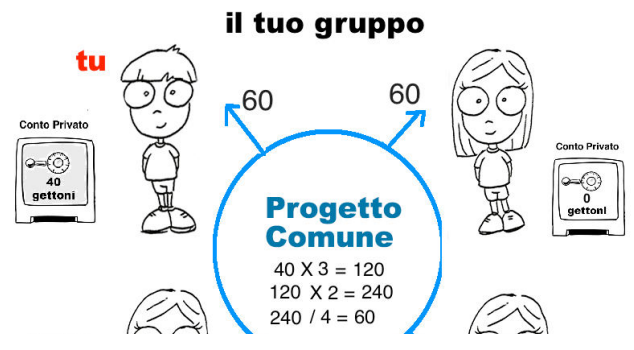




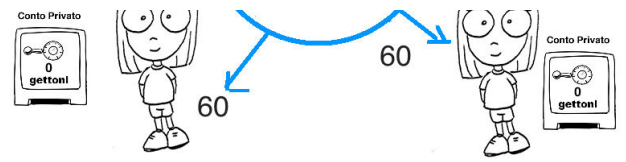

Tu in questo caso otterrai i 60 gettoni del progetto comune più i 40 gettoni che avevi tenuto nel tuo conto privato, quindi in totale 100 gettoni, mentre gli altri componenti otterranno solamente i 60 gettoni del progetto comune.

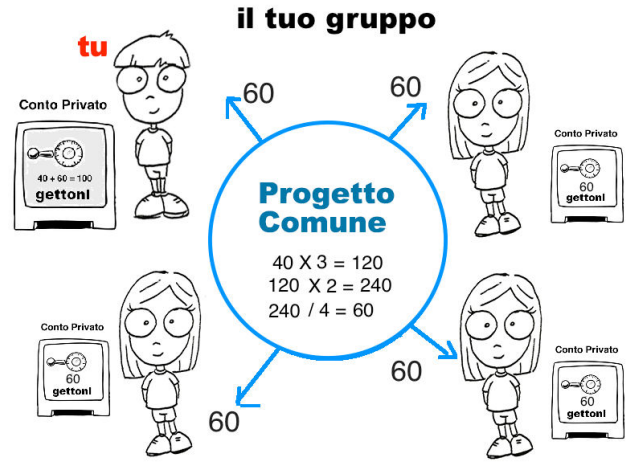

\section{E' tutto chiaro?}

Ci sono domande?

Le istruzioni resteranno disponibili in fondo alla schermata per tutta la durata di questa parte dello studio cliccando sul bottone "Clicca Per Rileggere le istruzioni"

Nella prossima pagina ti chiederemo di rispondere ad alcune domande che NON AVRANNO EFFETTO sul tuo compenso finale, ma che servono a te per verificare di aver compreso correttamente le istruzioni.

Quando sei pronto per iniziare puoi cliccare sul bottone 'Successivo' qui sotto.

Successivo 


\section{Prima Parte - Domanda di comprensione}

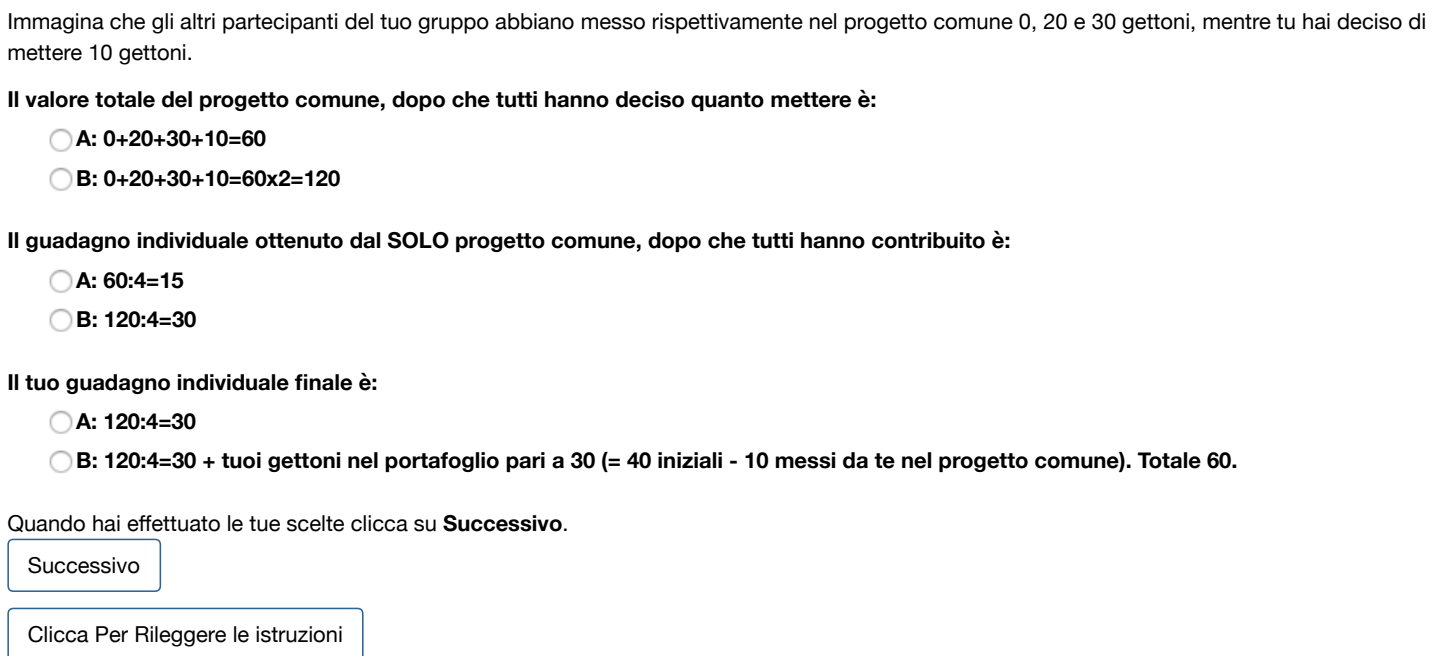




\title{
Prima Parte - Soluzione della domande di comprensione
}

\author{
La tua risposta 'Il valore totale del progetto comune, dopo che tutti hanno deciso quanto mettere è: $B: 0+20+30+10=60 \times 2=120$ ' era corretta. \\ La tua risposta 'Il guadagno individuale ottenuto dal SOLO progetto comune, dopo che tutti hanno contribuito è:: B: 120:4=30' era corretta. \\ La tua risposta 'II Suo compenso individuale finale è: B: 120:4=30 + tuoi gettoni nel portafoglio pari a 30 (= 40 iniziali - 10 messi da te nel \\ progetto comune). Totale 60. ' era corretta. \\ Spiegazione soluzione prima domanda: \\ il guadagno ottenuto dal progetto comune è pari a 120. Infatti la somma dei gettoni messi dai quattro componenti del gruppo è pari a 60 ma visto che \\ i gettoni messi nel progetto comune raddoppiano di valore, questi 60 diventano $60 \times 2=120$. La risposta esatta alla prima domanda era quindi 120 . \\ Spiegazione soluzione seconda domanda: \\ II valore del progetto comune è 120. Visto che i gettoni del progetto comune dopo essere stati raddoppiati, vengono divisi equamente tra i 4 \\ componenti del gruppo, allora i 120 gettoni del progetto comune, divisi per 4 danno 30 gettoni ognuno. La risposta esatta è quindi 30. \\ Spiegazione soluzione terza domanda: \\ I gettoni che ogni componente del gruppo ottiene dal progetto comune sono 30. Tu hai deciso di mettere, in questo esempio, 10 gettoni. Quindi, \\ restavano nel tuo conto privato 30 gettoni che sommati al compenso del progetto comune fanno $30+30=60$. La risposta esatta era quindi 60 \\ gettoni. \\ Hai completato le domande di comprensione, adesso possiamo iniziare il test vero e proprio. \\ Quando sei pronto per iniziare puoi cliccare sul bottone 'Successivo' qui sotto. \\ Successivo \\ Clicca Per Rileggere le istruzioni
}




\title{
Prima Parte - Decisione
}

\author{
Quanti gettoni metti nel progetto comune? \\ 0 gettoni \\ 10 gettoni \\ $\odot 20$ gettoni \\ 30 gettoni \\ 40 gettoni
}

Clicca su 'Successivo' quando hai scelto.

Successivo

Clicca Per Rileggere le istruzioni 


\section{Seconda Parte - Istruzioni}

Ora il computer formerà in maniera casuale NUOVI gruppi di 4 partecipanti. Come nella Prima Parte, in questa Seconda Parte devi compiere due decisioni.

Clicca su 'Successivo' per continuare.

Successivo 


\title{
Seconda Parte - Prima decisione - Istruzioni
}

\author{
Istruzioni \\ Come nella Prima Parte, hai a disposizione 40 gettoni. Devi scegliere quanti di questi gettoni tenere nel tuo conto privato e quanti metterne in \\ un progetto comune. \\ Come nelle parti precedenti devi decidere un ammontare di gettoni da mettere nel progetto comune in misura pari ai seguenti valori: \\ $0,10,20,30,40$. \\ Cosa avviene in seguito alla tua scelta? \\ Come prima, i gettoni che metti nel progetto comune vengono raddoppiati e poi successivamente divisi equamente tra i 4 membri del gruppo. \\ I gettoni che NON metti nel progetto comune, restano nel tuo conto privato. \\ Attenzione! In questa parte avrai la possibilità di decidere di NON partecipare ed ottenere un bonus fisso di 40 gettoni.
}

Clicca su 'Successivo' per continuare.

Successivo 


\section{Seconda Parte - Seconda Decisione - Istruzioni}

Istruzioni

Nella seconda decisione, devi scegliere tra tre possibili azioni, A, B ० C, da associare ad ognuna delle sei scelte riportate sotto. Le tre azioni A, B e C corrispondono a:

Azione A: Paghi 0 gettoni, e l'altro componente del gruppo perde 0 gettoni.

Azione B: Paghi 4 gettoni, e l'altro componente del gruppo perde 12 gettoni.

Azione C: Paghi 8 gettoni, e l'altro componente del gruppo perde 24 gettoni.

\section{Decisione 2}

In questa decisione

devi scegliere tra tre possibili azioni,

A, B, C.

Ognuna di esse

implica una conseguenza

nei confronti degli altri

tre componenti del gruppo

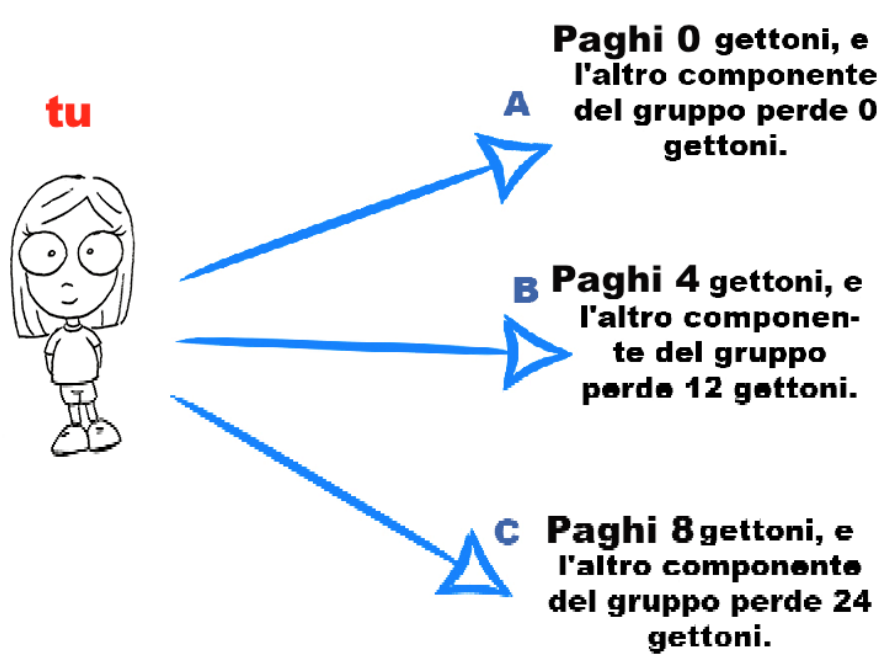

Paghi 0 gettoni, e l'altro componente gettoni.

ttoni.

In pratica, ti viene chiesto di scegliere un'azione per ogni possibile decisione DEGLI ALTRI COMPONENTI DEL TUO GRUPPO

Che cosa vuol dire? Guarda qui sotto:

Scelta 1. Azione verso chi non ha partecipato: $A, B, o C$ ?

Scelta 2. Azione verso chi ha messo 0 gettoni nel progetto comune: $A, B$, o $C$ ?

Scelta 3. Azione verso chi ha messo 10 gettoni nel progetto comune: $A, B$, o $C$ ?

Scelta 4. Azione verso chi ha messo 20 gettoni nel progetto comune: $A, B, o C$ ?

Scelta 5. Azione verso chi ha messo $\mathbf{3 0}$ gettoni nel progetto comune: $A, B, o C$ ?

Scelta 6. Azione verso chi ha messo 40 gettoni nel progetto comune: $A, B$, o $C$ ?

In pratica ogni Scelta corrisponde all'azione che vuoi intraprendere nei confronti di ognuna delle decisioni possibili degli altri.

TU NON SAPRAI ESATTAMENTE NEI CONFRONTI DI QUALE MEMBRO DEL GRUPPO AVRANNO EFFETTO LE AZIONI INDICATE IN QUESTA SECONDA DECISIONE. Una volta effettuate le sei scelte, il computer selezionerà a caso un membro del tuo gruppo verso cui avrà effetto la tua Scelta.

Dopo aver osservato i risultati della Prima decisione, potrai decidere le tue azioni. 


\section{Facciamo un esempio.}

Supponiamo che il computer abbia scelto di associare a te, un membro del gruppo che ha messo 0 gettoni nel progetto comune. Sarà rispetto a questo componente (anonimo) che avrà effetto la tua azione indicata nelle sei Scelte. Supponiamo che tu abbia indicato nella Scelta 2, l'azione C: questo partecipante vedrà ridursi di 24 gettoni il suo compenso e in questo caso tu pagherai 8 gettoni.

Egualmente, il computer sceglierà un partecipante che deciderà un' azione nei tuoi confronti: il ragionamento da fare è lo stesso. Se hai messo 30 gettoni e il partecipante ha deciso B nella Scelta 4, tu perdi 8 gettoni e il partecipante che ha deciso B paga 4 gettoni. Infatti la scelta 4 , indica l'azione che quel partecipante voleva attuare nei confronti di un membro del gruppo che aveva messo 30 , e tu avevi messo proprio 30 .

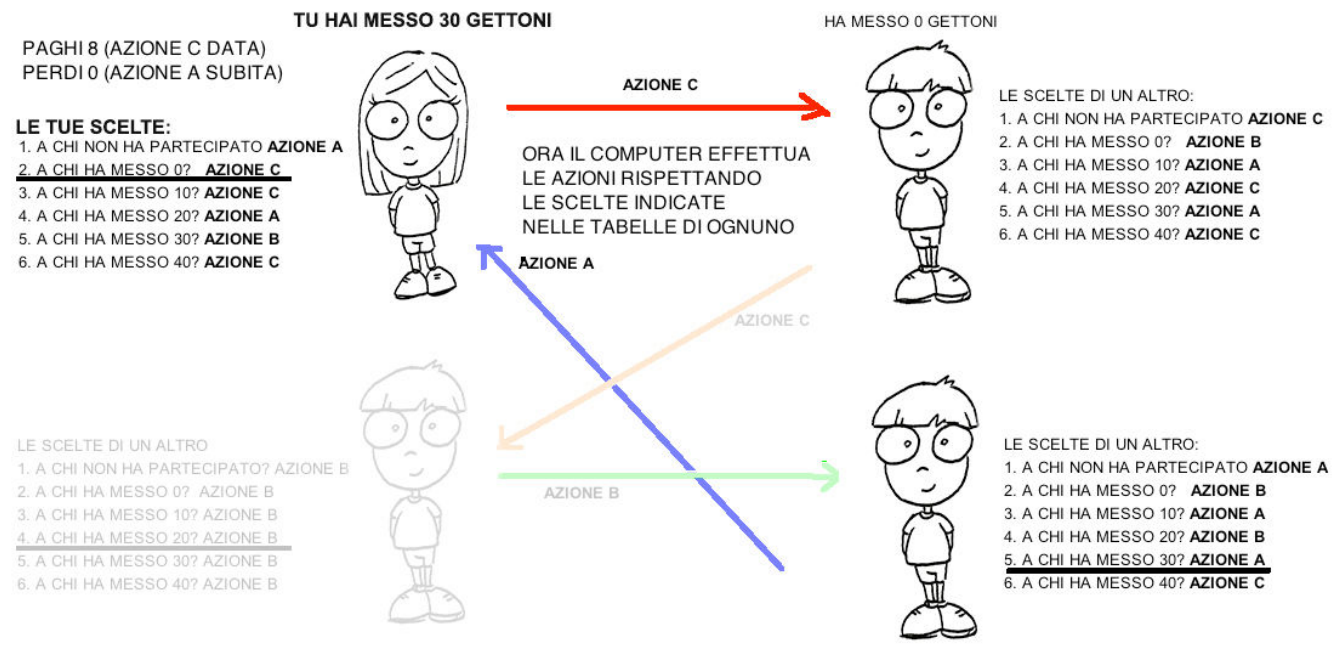

Non esitare ad alzare la mano qualora ci fossero delle domande. Uno di noi verrà da te per risponderti.

Nella prossima schermata dovrai rispondere a delle domande che NON AVRANNO EFFETTO sul tuo compenso finale, ma che servono a te per verificare di aver compreso correttamente le istruzioni.

Clicca su 'Successivo' per continuare.

Successivo 


\section{Seconda Parte - Domande di comprensione}

Supponiamo che nella prima decisione hai deciso di mettere 40 gettoni nel progetto comune.

Gli altri partecipanti del tuo gruppo hanno messo rispettivamente $10,20,30$. In totale quindi il progetto comune ha 100 gettoni che diventano 200 dopo essere stati moltiplicati per due.

Nella Seconda Decisione hai effettuato le seguenti scelte:

Scelta 1.: azione A ai membri del gruppo che hanno messo 0 gettoni nel progetto comune, hai deciso di togliere 0 , pagando 0 Scelta 2.: azione A ai membri del gruppo che hanno messo 10 gettoni nel progetto comune, hai deciso di togliere 0 , pagando 0 Scelta 3.: azione $\mathrm{C}$ ai membri del gruppo che hanno messo 20 gettoni nel progetto comune, hai deciso di togliere 24 , pagando 8 Scelta 4.: azione B ai membri del gruppo che hanno messo 30 gettoni nel progetto comune, hai deciso di togliere 12, pagando 4 Scelta 5.: azione $\mathrm{C}$ ai membri del gruppo che hanno messo 40 gettoni nel progetto comune, hai deciso di togliere 24 , pagando 8

In totale, quanti gettoni ottieni dal progetto comune, prima di decidere quanti gettoni eventualmente togliere agli altri?

$$
\begin{aligned}
& 25 \text { gettoni } \\
& 50 \text { gettoni } \\
& 100 \text { gettoni }
\end{aligned}
$$

Se il computer seleziona la tua scelta di quanti gettoni togliere ad un altro componente che ha messo 40 gettoni nel progetto comune, quanti gettoni perdi?
24 gettoni
0 gettoni
8 gettoni

Quale compenso finale ottieni, se hai scelto di togliere $\mathbf{2 4}$ gettoni ad un soggetto?

40 dal progetto +40 del tuo conto privato -8 che hai speso per togliere gettoni ad un altro

- 50 dal progetto +0 del tuo conto privato -8 che hai speso per togliere gettoni ad un altro

0 dal progetto $+\mathbf{4 0}$ del tuo conto privato $-\mathbf{8}$ che hai speso per togliere punti ad un altro

Clicca su 'Successivo' per continuare.

Successivo

Clicca Per Rileggere le istruzioni 


\section{Seconda Parte - Soluzione delle domande di comprensione}

La tua risposta alla domanda'In totale, quanti gettoni ottieni dal progetto comune?' è stata: 50 gettoni Questa risposta era corretta.

La tua risposta alla domanda'Se il computer seleziona la tua scelta di quanti gettoni togliere ad un altro componente che ha messo $\mathbf{4 0}$ gettoni nel progetto comune, quanti gettoni perdi?' è stata: $\mathbf{0}$ gettoni Questa risposta era sbagliata.

La tua risposta alla domanda'Quale compenso finale ottieni, se hai scelto di togliere 24 gettoni ad un soggetto?' è stata: $\mathbf{0}$ dal progetto $+\mathbf{4 0}$ del tuo conto privato $-\mathbf{8}$ che hai speso per togliere punti ad un altro Questa risposta era sbagliata.

Spiegazione:

Soluzione prima domanda: La somma dei gettoni messi dai componenti del tuo gruppo incluso te è pari a $40+10$ $+20+30=100$. I gettoni messi nel progetto comune vengono moltiplicati per 2 , quindi il valore del progetto sarà ora pari a $100 \times 2=200$. Tali gettoni vengono divisi equamente tra i 4 componenti del gruppo, quindi ognuno otterrà dal progetto comune $200: 4=50$ gettoni.

Soluzione seconda domanda: Se tu avevi indicato azione $\mathrm{C}$ in corrispondenza di un componente che avesse deciso di mettere 40 gettoni nel progetto comune, in questo caso quindi, il componente perde 24 gettoni mentre tu ne paghi 8.

Soluzione terza domanda: Tu hai scelto l'azione C, che corrisponde a togliere 24 gettoni ad un componente del tuo gruppo. Scegliendo C, paghi 8 gettoni. Avevi però ottenuto 50 gettoni dal progetto comune ma non ti erano rimasti gettoni nel conto privato. Quindi ottieni 50 gettoni dal progetto +0 del tuo conto privato -8 che hai speso per togliere gettoni ad un altro.

E' tutto chiaro? Per procedere con la scelta clicca su 'Successivo'

Successivo 


\section{Seconda Parte - Prima Decisione}

Tu puoi scegliere ora di:

i. partecipare a questa parte del gioco

ii. non partecipare e ottenere 40 punti (indipendentemente da ciò che decidono gli altri).

Cosa decidi?

Vuoi partecipare?

Si

No

Clicca sul bottone 'Successivo' per continuare.

Successivo

Clicca Per Rileggere le istruzioni 


\section{Seconda Parte - Prima Decisione}

Quanti gettoni metti nel progetto comune?
0 gettoni
10 gettoni
20 gettoni
30 gettoni
40 gettoni

Clicca sul bottone 'Successivo' quando hai effettuato la tua scelta.

Successivo

Clicca Per Rileggere le istruzioni 


\section{Seconda Parte - Seconda Decisione}

\section{Risultato Prima Decisione}

Tu hai messo nel progetto comune 10 gettoni. Gli altri membri del tuo gruppo hanno effettuato le seguenti scelte:

- non partecipare

- partecipare mettendo 40 punti

- partecipare mettendo 40 punti

In sintesi 3 membri del tuo gruppo hanno deciso di partecipare (tu compreso), mettendo in totale nel progetto comune 90 punti. Tu ottieni quindi dal progetto comune 60 punti. Il tuo compenso per questa prima decisione è quindi 90 punti.

\section{Seconda Decisione}

Ora devi effettuare la seconda decisione. Puoi tener conto del risultato della prima decisione riportato qui sopra. Ricordati che ora hai a disposizione le seguenti azioni in relazione alle 6 scelte sotto elencate:

A. Azione A: Paghi 0 gettoni, e l'altro componente del gruppo perde 0 gettoni.

B. Azione B: Paghi 4 gettoni, e l'altro componente del gruppo perde 12 gettoni.

C. Azione C: Paghi 8 gettoni, e l'altro componente del gruppo perde 24 gettoni.

1. Quale azione vuoi intraprendere nei confronti di un giocatore che non ha partecipato al progetto?

azione A
azione B
azione C

2. Quale azione vuoi intraprendere nei confronti di un componente del gruppo che ha messo 0 gettoni nel progetto comune?

azione A

azione B

$\odot$ azione C

3. Quale azione vuoi intraprendere nei confronti di un componente del gruppo che ha messo 10 gettoni nel progetto comune?

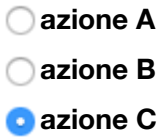

4. Quale azione vuoi intraprendere nei confronti di un componente del gruppo che ha messo 20 gettoni nel progetto comune?

azione $A$ 


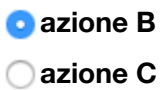

5. Quale azione vuoi intraprendere nei confronti di un componente del gruppo che ha messo 30 gettoni nel progetto comune?

$$
\begin{gathered}
\text { azione A } \\
\text { azione B } \\
\text { azione C }
\end{gathered}
$$

6. Quale azione vuoi intraprendere nei confronti di un componente del gruppo che ha messo 40 gettoni nel progetto comune?

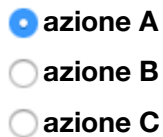

Clicca Per Rileggere le istruzioni 


\section{Terza Parte - Istruzioni}

Ora il computer formerà NUOVI gruppi di 4 partecipanti, in maniera casuale.

In questa parte dello studio devi prendere DUE decisioni che avranno un effetto sul tuo compenso finale.

Clicca su 'Successivo' per continuare.

Successivo 


\title{
Terza Parte - Prima Decisione - Istruzioni
}

\author{
Istruzioni \\ Come nelle parti precedenti, hai a disposizione 40 gettoni. Devei scegliere quanti di questi gettoni tenere nel \\ tuo conto privato e quanti metterne in un progetto comune.
}

Puoi scegliere uno dei seguenti valori: $0,10,20,30,40$.

Come nelle parti precedenti, i gettoni che metti nel progetto comune vengono raddoppiati e poi successivamente divisi equamente tra i 4 membri del gruppo.

I gettoni che NON metti nel progetto comune, restano nel tuo conto privato.

Attenzione: In questa parte dello studio, non puoi decidere di non partecipare.

Successivo 


\section{Terza Parte - Seconda Decisione - Istruzioni}

\section{Istruzioni}

Nella seconda decisione, devi scegliere tra tre possibili azioni, A, B o C, da associare ad ognuna delle cinque scelte riportate sotto. Le tre azioni $A, B$ e $C$ corrispondono a:

Azione A: Paghi 0 gettoni, e l'altro componente del gruppo perde 0 gettoni.

Azione B: Paghi 4 gettoni, e l'altro componente del gruppo perde 12 gettoni.

Azione C: Paghi 8 gettoni, e l'altro componente del gruppo perde 24 gettoni.

Come prima, ti viene chiesto di scegliere un'azione per ogni possibile decisione DEGLI ALTRI COMPONENTI DEL TUO GRUPPO, indicando una azione per ogni possibile scelta degli altri, come segue:

Scelta 1. Azione verso chi ha messo 0 gettoni nel progetto comune: $A, B$, o $C$ ?

Scelta 2. Azione verso chi ha messo 10 gettoni nel progetto comune: $A, B, \circ C$ ?

Scelta 3. Azione verso chi ha messo 20 gettoni nel progetto comune: $A, B, o C$ ?

Scelta 4. Azione verso chi ha messo $\mathbf{3 0}$ gettoni nel progetto comune: $A, B$, o $C$ ?

Scelta 5. Azione verso chi ha messo $\mathbf{4 0}$ gettoni nel progetto comune: $A, B$, o $C$ ?

Attenzione! L'unica differenza rispetto alla Seconda Decisione della Seconda Parte dello studio, è che nè tu nè gli altri partecipanti potete decidere di NON PARTECIPARE alla prima decisione, e quindi non è neanche possibile decidere una azione nei confronti DI CHI NON PARTECIPA al progetto comune.

Anche in questo caso, TU NON SAPRAI ESATTAMENTE NEI CONFRONTI DI QUALE MEMBRO DEL GRUPPO AVRANNO EFFETTO LE AZIONI INDICATE NELLA SECONDA DECISIONE. Una volta effettuate le cinque scelte, il computer selezionerà a caso un membro del tuo gruppo verso cui avrà effetto la tua azione. Potrai decidere le tue azioni, dopo aver osservato i risultati della Prima decisione.

$E^{\prime}$ tutto chiaro? 
Le istruzioni resteranno disponibili in fondo alla schermata per tutta la durata dello studio.

Alza la mano se hai delle domande da fare. Uno di noi verrà da te per risponderti.

Clicca su 'Successivo' quando sei pronto per continuare.

Successivo 


\title{
Terza Parte - Prima Decisione
}

\author{
Quanti gettoni metti nel progetto comune? \\ 0 gettoni \\ C 10 gettoni \\ 20 gettoni \\ 30 gettoni \\ 40 gettoni
}

Quando hai deciso clicca su 'Successivo'.

Successivo

Clicca Per Rileggere le istruzioni 


\section{Terza Parte - Seconda Decisione}

\section{Risultato Prima Decisione}

Hai messo nel progetto comune 10 gettoni.

Gli altri membri del gruppo hanno messo:

- 30 punti,

- 30 punti,

- 10 punti.

La somma totale dei gettoni messi nel progetto comune è 80 punti. Ciascuno dei componenti del gruppo ha ottenuto quindi dal progetto comune 40 punti.

II tuo compenso per la prima decisione è quindi 70 punti.

\section{Seconda Decisione}

Ora devi effettuare la seconda decisione. Puoi tener conto del risultato della prima decisione riportato qui sopra. Ricordati che hai a disposizione le seguenti azioni:

A. Azione A: Paghi 0 gettoni, e l'altro componente del gruppo perde 0 gettoni.

B. Azione B: Paghi 4 gettoni, e l'altro componente del gruppo perde 12 gettoni.

C. Azione C: Paghi 8 gettoni, e l'altro componente del gruppo perde 24 gettoni.

1. Quale azione vuoi intraprendere nei confronti di un componente del gruppo che ha messo 0 gettoni nel progetto comune?

azione A

azione B

azione C

2. Quale azione vuoi intraprendere nei confronti di un componente del gruppo che ha messo 10 gettoni nel progetto comune?

azione A

azione B

azione C

3. Quale azione vuoi intraprendere nei confronti di un componente del gruppo che ha messo 20 gettoni nel progetto comune?

azione A

azione $B$

azione C 
4. Quale azione vuoi intraprendere nei confronti di un componente del gruppo che ha messo $\mathbf{3 0}$ gettoni nel progetto comune?

azione A

azione B

azione C

5. Quale azione vuoi intraprendere nei confronti di un componente del gruppo che ha messo 40 gettoni nel progetto comune?

azione A

azione B

azione C

Successivo

Clicca Per Rileggere le istruzioni 


\section{Quarta Parte - Istruzioni}

Ora il computer formerà NUOVI gruppi di 4 partecipanti, in maniera casuale.

Successivo 


\section{Quarta Parte - Istruzioni}

\section{Istruzioni}

Devi scegliere un numero tra 0 e 100, inclusi 0 e 100.

Diversamente dalle parti precedenti, in questa parte c'è un vincitore per ogni gruppo.

\section{Chi è il vincitore}

Vince chi sceglie il numero che si avvicina di più alla media dei numeri scelti dai componenti del proprio gruppo, moltiplicata per 2/3.

Il vincitore ottiene 50 gettoni, mentre gli altri partecipanti non ricevono nulla. In caso di parità i 50 gettoni vengono divisi equamente tra tutti i vincitori.

1
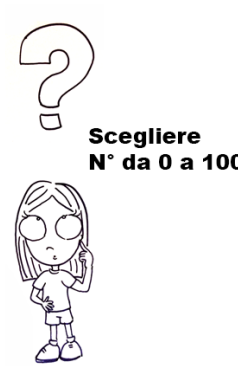
Scegliere

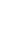

(

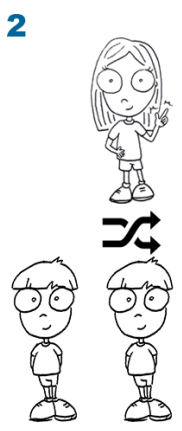

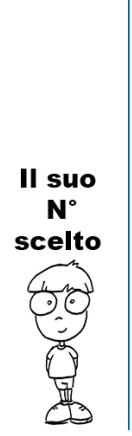

3

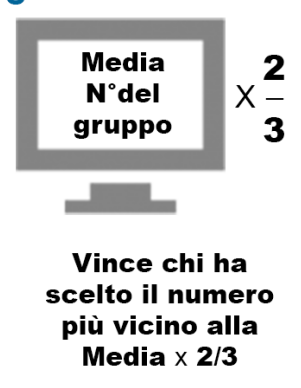

4

ESEMPIO

Se Lei sceglie 50 ,

e gli altri componenti scelgono 100,50 e 0 . Il totale è 200 . Diviso 4 fa 50.

Risulterà: $50 * 2=100 / 3=33,3$

\section{Esempio}

Immaginiamo che tu scelga 15 , e gli altri componenti scelgano 25,58 e 12 . Il totale fa: $15+25+58+12=$ 110. Per ottenere la media devo dividere questa somma per 4: quindi 110 diviso 4 ottengo 27,5 . Poi per ottenere il numero vincente devi moltiplicare per 2/3 (quindi moltiplicare la media per 2 e poi dividere per 3); nel nostro esempio il numero da indovinare si ottiene così: $27,5 \times 2=55$ e poi 55:3=18,3 (circa, non importano le cifre dopo la virgola, quindi diciamo 18).

Vince chi ha scelto 15 perchè è il numero più vicino 18.

In questo caso quindi, hai vinto perchè hai scelto 15 e ottieni 50 punti.

E' tutto chiaro? Ci sono domande? 
Nella prossima pagina dovrai rispondere a due domande che non avranno effetto sul tuo compenso finale, ma che servono a garantire che tu abbia compreso correttamente le istruzioni. Quando sei pronto per continuare clicca su Successivo.

Successivo 


\section{Quarta parte - Domande di comprensione}

Immagina di aver scelto il numero 20 e che gli altri partecipanti del tuo gruppo abbiano scelto i numeri 10, 20 e 70.

La media di tutti i numeri scelti è 30 . Qual è il numero scelto dal vincitore?

II vincitore ha scelto:

Qual è il tuo compenso?

II tuo compenso è:

punti

Successivo

Clicca Per Rileggere le istruzioni 


\title{
Quarta Parte - Soluzione della domanda di comprensione
}

\author{
La tua risposta 'll vincitore ha scelto: 54 ' era sbagliata. \\ La tua risposta 'Il tuo compenso è: $\mathbf{5 4}$ punti' era sbagliata. \\ Immagina di aver scelto il numero 20 e che gli altri partecipanti del tuo gruppo abbiano scelto i numeri 10, 20 e 70. \\ La media di tutti i numeri scelti è 30. Qual è il numero scelto dal vincitore? Qual è il tuo compenso? \\ Soluzione: II vincitore ha scelto 20 e il tuo compenso è 25 punti. \\ Spiegazione: La media di tutti i numeri scelti era $(20+10+20+70)=120: 4=30$ come indicato. I due-terzi di 30 è pari \\ è $30 \times 2=60: 3=20$. \\ 20 è risultato essere il numero più vicino a 30 . Quindi tu e il partecipante che ha scelto 20 siete risultati vincitori. \\ Ognuno di Voi riceve 25 punti. \\ E' tutto chiaro? Quando sei pronto per continuare, clicca su Successivo. \\ Successivo \\ Clicca Per Rileggere le istruzioni
}




\section{Quarta Parte - Decisione}

Per favore scegli un numero da 0 a 100:

Successivo

Clicca Per Rileggere le istruzioni 


\section{Quarta Parte - Un commento sulla tua scelta}

Ora ti chiediamo per favore di scrivere sul foglio che hai sul tavolo, un commento sulla scelta che hai effettuato in questa parte dello studio.

Hai applicato una regola? Se si, puoi descriverci brevemente quale?

Clicca su 'Successivo' quando sei pronto per proseguire.

Successivo 


\section{Quinta Parte - Istruzioni}

Ora il computer formerà NUOVI gruppi di 4 partecipanti, in maniera casuale.

Successivo 


\section{Quinta Parte - Istruzioni}

\section{Istruzioni}

In questa parte dello studio trovi tre scelte che indicano i possibili gettoni da assegnare ai quattro componenti del tuo gruppo.

Nota bene che il totale dei gettoni da assegnare al gruppo non cambia per le tre scelte. Cambia solo il numero di gettoni assegnato a ciascun componente.

Le scelte possibili sono le seguenti:

$$
\text { TOTALE }=96 \text { SCELTA A }
$$

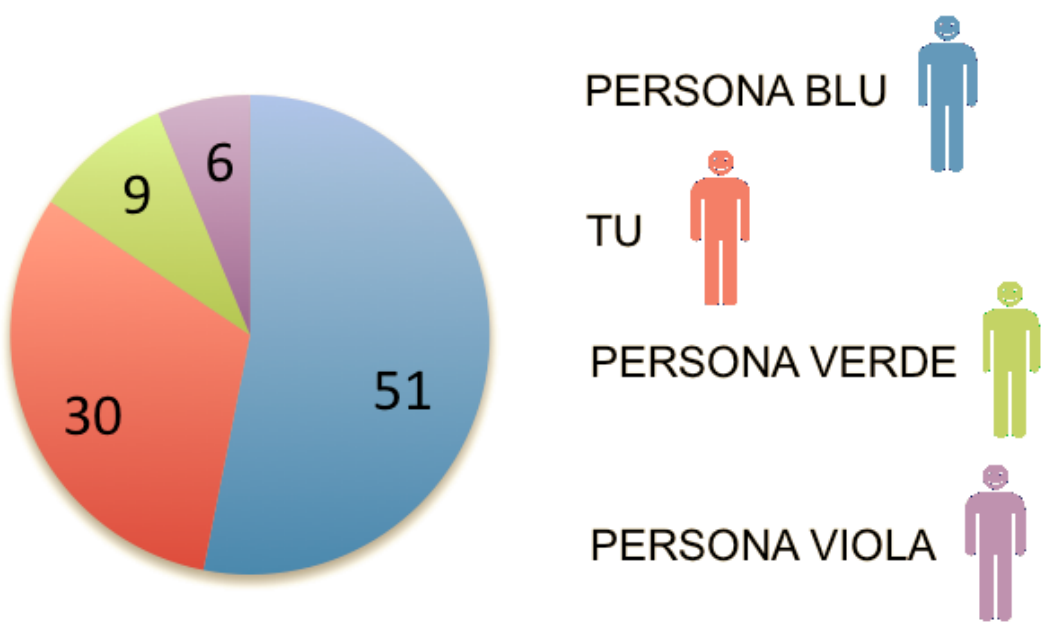

Scelta A 


\section{TOTALE $=96 \quad$ SCELTA B}
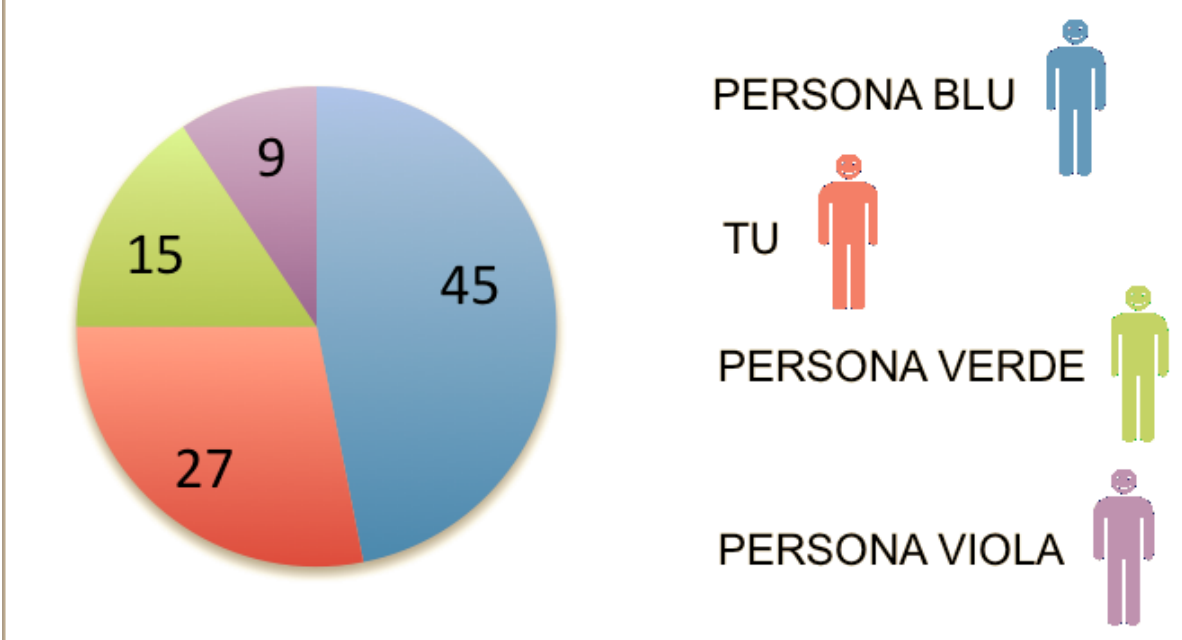

Scelta B

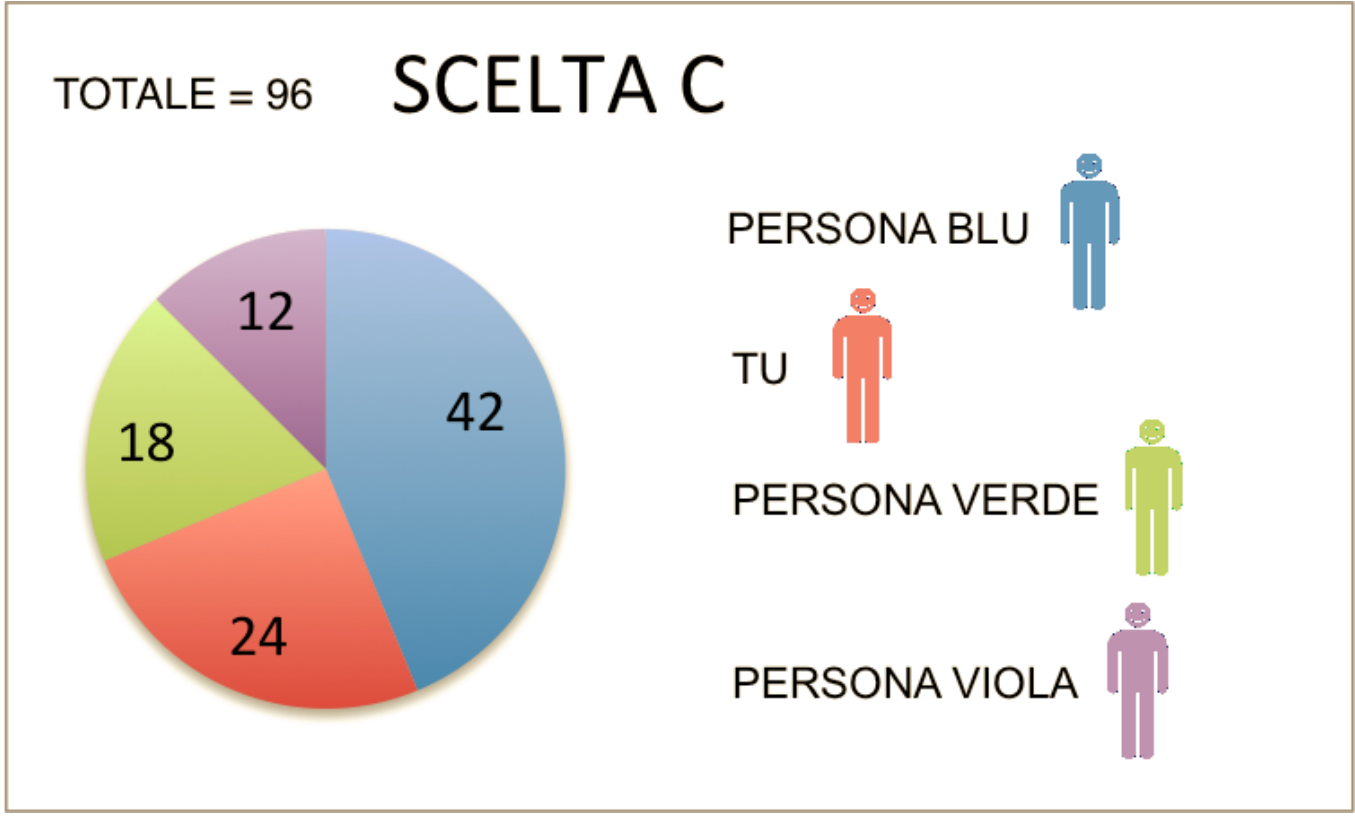

Scelta C

Cosa devi fare? Devi indicare quale scelta preferisce.

Come viene determinato il tuo compenso? 
Quando tutti avrete effettuato la vostra scelta, il computer estrarrà a caso chi deciderà i compensi di tutti.

\section{Se ad esempio vieni estratto TU, saranno le tue scelte a determinare i compensi di tutti.}

Quindi, se tu vieni estratto dal computer, prenderai il compenso indicato in ROSSO con la scritta TU, mentre gli altri componenti del gruppo prenderanno un numero di gettoni pari a quelli indicati nel disegno, a seconda che vengano estratti per essere Persona BLU, VERDE o VIOLA.

Se tu scegli A ad esempio, e vieni estratto per decidere i compensi di tutti, tu prendi 30 gettoni, gli altri ottengono 51, 9, e 6 gettoni a seconda che siano estratti per essere Persona BLU, Persona VERDE o Persona VIOLA.

E' il computer a decidere chi è Persona BLU, Persona VERDE o Persona VIOLA.

Invece, nel caso non venga estratto tu per decidere i compensi di tutti, ma un altro, le scelte di quest'ultimo determineranno il tuo guadagno. II tuo guadagno corrisponderà al guadagno indicato con Persona BLU, Persona VERDE o Persona VIOLA a seconda che il computer ti estragga per essere Persona BLU, Persona VERDE o Persona VIOLA.

Se ad esempio la persona estratta dal computer per decidere i compensi di tutti aveva indicato la Scelta C, questa persona ottiene 24 gettoni; se tu invece sei stato estratto dal computer per essere Persona VIOLA, tu ottieni 12 gettoni, gli altri due componenti del gruppo ottengono 18 e 42 gettoni.

Se invece la persona estratta per decidere i compensi di tutti aveva indicato la scelta A, questa persona ottiene 30 gettoni; se tu vieni estratto per essere Persona BLU, ottieni 51 gettoni, gli altri componenti ottengono, 6 e 9 gettoni.

Le istruzioni resteranno disponibili sullo schermo per tutta la durata di questa parte dello studio.

Non esitare ad alzare la mano se hai delle domande. Uno di noi verrà da te per risponderti.

Prima di effettuare la scelta, ti chiediamo di rispondere a due domande che NON AVRANNO EFFETTO sul tuo compenso finale, ma che servono a te per verificare di aver compreso le istruzioni.

Clicca su Successivo quando sei pronto per continuare.

Successivo

\section{Debug info}

Basic info 


\section{Quinta Parte - Domande di comprensione}

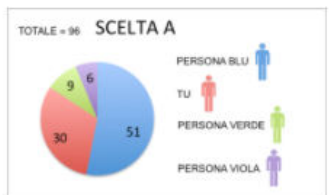

Scelta A

Immagina di avere scelto $\mathbf{B}$

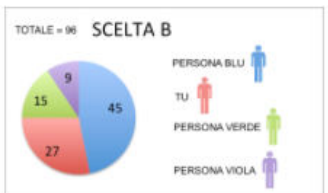

Scelta B

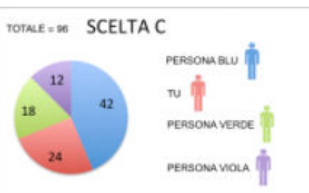

Scelta C

Se tu vieni selezionato dal computer per decidere i compensi di tutti, tu guadagni:

15 gettoni

27 gettoni

Immagina di avere scelto $\mathbf{A}$.

Se un altro componente del tuo gruppo viene estratto per decidere i compensi di tutti e questa persona sceglie C. In questo caso tu guadagni:

42 oppure 18 oppure 12 gettoni, a seconda del ruolo che il computer estrae a caso e ti assegna

45 oppure 15 oppure 9 gettoni, a seconda del ruolo che il computer estrae a caso e ti assegna

Successivo

Clicca Per Rileggere le istruzioni 


\section{Quinta Parte - Soluzione delle domande di comprensione}

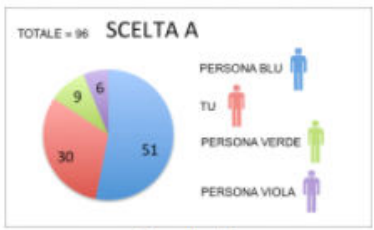

Scelta A

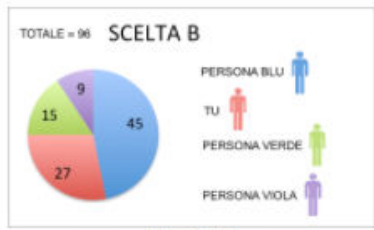

Scelta B

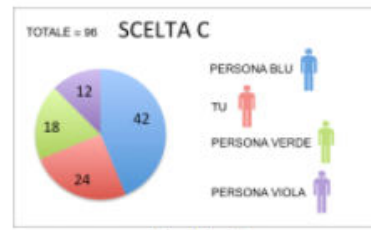

Scelta C

La tua risposta 'Tu avevi scelto B. Se tu vieni selezionato dal computer per decidere i compensi di tutti, tu guadagni: $\mathbf{2 7}$ gettoni' era corretta.

La tua risposta 'Se un altro componente del tuo gruppo viene estratto per decidere i compensi di tutti e questa persona sceglie C, in questo caso tu guadagni: 42 oppure 18 oppure 12 gettoni, a seconda del ruolo che il computer estrae a caso e ti assegna' era corretta.

Soluzione prima domanda: Se tu vieni scelto dal computer per decidere i compensi di tutti i componenti del tuo gruppo e scegli B, allora otterrai il compenso indicato in rosso con TU, cioè 27 gettoni. Gli altri tre componenti otterranno rispettivamente 45, 15, e 9 gettoni, a seconda che vengano estratti per essere Persona BLU, Persona VERDE o Persona VIOLA.

Soluzione seconda domanda: Invece, se il computer estrae un'altro componente del tuo gruppo per decidere i compensi di tutti i componenti del gruppo, e questo componente ha scelto ad esempio C, tu puoi ottenere 42, 18 o 12 gettoni a seconda che tu venga estratto per essere Persona BLU, Persona VERDE o Persona VIOLA. 


\section{Quinta Parte - Decisione}

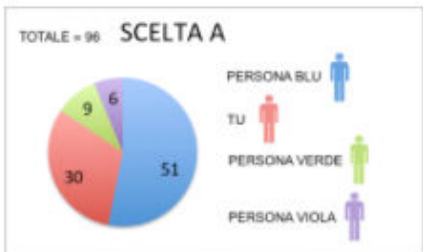

Scelta A

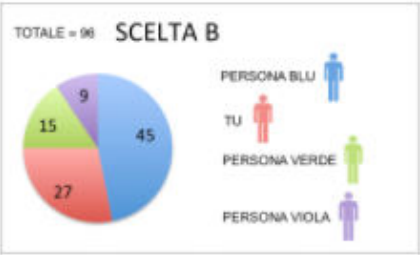

Scelta B

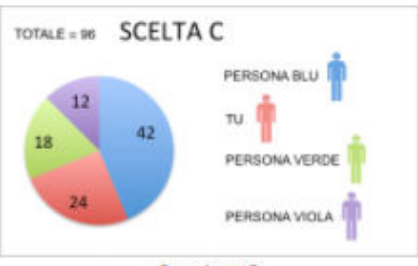

Scelta C

Ora puoi effettuare la tua scelta :
Scelta A
Scelta B
Scelta C

Successivo

Clicca Per Rileggere le istruzioni 


\section{Quinta Parte - Un commento sulla tua scelta}

Ora ti chiediamo per favore di scrivere sul foglio che hai sul tavolo, un commento sulla scelta che hai effettuato in questa parte dello studio.

Hai applicato una regola? Se si, puoi descriverci brevemente quale?

Clicca su 'Successivo' quando sei pronto per proseguire.

Successivo 


\section{S3.5 Results in detail}

\section{I tuoi risultati}

Grazie per aver partecipato a questo studio, ecco di seguito i tuoi risultati.

\section{PRIMA PARTE}

Per quanto riguarda la questa decisione, hai iniziato questa parte dello studio con una dotazione di 40 punti. Hai deciso di contribuire 30 gettoni. Il tuo gruppo ha contribuito un totale di 90 punti, da cui consegue un compenso individuale di partecipazione di 45 punti. Il compenso da te ottenuto per la seconda decisione é dunque: 55 punti.

Il tuo compenso per questa parte è dunque 55 punti

Per questa parte verrai pagato: $€ 2.20$

\section{SECONDA PARTE}

Avevi a disposizione nel tuo conto privato 40 punti, ed hai messo 40 gettoni nel progetto comune.

Il tuo gruppo ha messo nel progetto comune in totale 160 punti, quindi il compenso dal progetto comune è risultato essere 80 punti.

Data la tua scelta, un altro partecipante ha deciso di toglierti 24 punti.

La tua azione verso un altro partecipante ti è costata 8 punti.

Il tuo compenso per questa parte è 48 punti.

Per questa parte dello studio ti verrà pagato: $€ 1.92$

TERZA PARTE Tu avevi a disposizione 40 punti nel tuo conto privato e hai deciso di partecipare a questa parte dello studio.

Tu hai contribuito 0 gettoni.

3 membri del tuo gruppo hanno deciso di partecipare in totale (Tu compreso). Il gruppo ha contribuito in totale 70 punti. La tua parte di compenso aggiuntivo ammonta dunque a: 47 punti. 
Data la tua scelta, uno degli altri giocatori ha deciso di toglierti 12 punti.

Inoltre la tua azione verso un altro partecipante ti é costata: 4 punti.

Quindi, il tuo compenso per questa parte dello studio è 71 punti.

Per questa parte verrai pagato: $€ 2.84$

\section{QUARTA PARTE}

Tu hai scelto 0 . Gli altri hanno scelto 0,0 , e 0 . I due terzi della media erano e il più vicino è stato 0,0. Ci sono 4 partecipanti che hanno scelto questo numero e tu sei stato uno di loro. Di conseguenza, ricevi 13 punti.

Per questa parte verrai pagato: €0.52

\section{QUINTA PARTE}

Tu hai scelto Scelta A.

Qualcun altro del tuo gruppo è stato selezionato come Persona 2.

Tu sei stato selezionato come Persona 1.

Quindi il tuo compenso per questa parte è 51 punti.

Per questa parte verrai dunque pagato: $€ 2.04$

COMPENSO DI PARTECIPAZIONE Quale compenso di partecipazione ti viene inoltre riconosciuto un compenso fisso di : $€ 5.00$

TI VERRA' PAGATO: $€ 14.52$

\section{PRIMA DI CONCLUDERE}

Ti ringraziamo per la tua disponibilità. Ti chiediamo un ultimo sforzo di pazienza mentre prepariamo i compensi di tutti. Nell'attesa ti chiediamo di rispondere ad un breve questionario. Le informazioni in esso contenute, cosi come i risultati dello studio finora svolto, saranno trattati con il massimo rispetto per la tua privacy e utilizzati soltanto per gli scopi scientifici del progetto. 


\section{S3.6 Survey in Italian}

Questionario 1 - Chiarezza dello studio

Grazie mille di aver partecipato a questo studio. In conclusione di questa esperienza vorremmo farle alcune domande.

Le istruzioni per le attività svolte oggi ti erano chiare?

Assolutamente Non chiare

Non particolarmente chiare

Abbastanza chiare

Molto chiare

Questo studio é stato realizzato con il supporto informatico del tablet che tu hai in mano. Vorremmo la Tua opinione sulla facilità di utilizzo di questo strumento dal tuo punto di vista. Ti prego di indicare la tua risposta su questa scala dove 1 corrisponde a "Assolutamente Difficile da usare" e 10 corrisponde a "Assolutamente Facile da usare":

1: Assolutamente Difficile da usare

$[2,3 \ldots]$

10: Assolutamente Facile da usare

Vorremmo ora la tua opinione sulla facilità di utilizzo della piattaforma software utilizzata per questo studio. Ti prego di indicare la tua risposta su questa scala dove 1 corrisponde a "Assolutamente Difficile da usare" e 10 corrisponde a "Assolutamente Facile da usare":

1: Assolutamente Difficile da usare

$[2,3 \ldots]$

10: Assolutamente Facile da usare.

Questionario 2

Quale é il tuo paese di cittadinanza? [LISTA]

Età? 
Sesso: M/F/Altro

\section{Questionario 3}

Per favore indica il tuo luogo di nascita:

In questa città o nei comuni limitrofi

Nella provincia ma fuori da questa città e dai comuni limitrofi

[Lista regioni italiane]

Estero

Per favore indica il luogo di nascita DI TUA MADRE:

\{Stesse opzioni che per il luogo di nascita\}

Per favore indica il luogo di nascita DI TUO PADRE:

$\{$ Stesse opzioni che per il luogo di nascita\}

Dove hai svolto le scuole elementari?

\{ Stesse opzioni che per il luogo di nascita\}

\section{Questionario 4}

Nel periodo del sisma del maggio-giugno 2012, risiedevi nella zona colpita dal terremoto?

$\mathrm{Si}$

No

La tua abitazione principale ha subito danni in conseguenza del terremoto? No, Nessun danno

A - agibile

B - temporaneamente inagibile, ma agibile con provvedimenti di pronto intervento

$\mathrm{C}$ - parzialmente inagibile

D - temporaneamente inagibile da rivedere con approfondimenti

E - inagibile 
$\mathrm{F}$ - inagibile per rischio esterno

Allo stato attuale, la tua abitazione principale è:

Agibile

In fase di ripristino

Non ancora ripristinata

\section{Nella fase di emergenza post-sisma:}

ho continuato a vivere nella mia abitazione

mi sono trasferito in altra abitazione nella zona del sisma

ho usufruito dei campi temporanei della protezione civile

ho spostato la mia residenza temporaneamente fuori dalla zona del sisma

ho spostato la mia residenza definitivamente fuori dalla zona del sisma

\section{Questionario 5}

La preghiamo di rispondere alle seguenti domande:

\section{Stato civile:}

Celibe/Nubile

Sposato

Separato

Divorziato

Vedovo

Di quante persone è composto il tuo nucleo familiare, includendo te stesso/a: 1

2

3

4

5 o più 
Sei tu la principale fonte di reddito per la tua famiglia? Sí

No

Ha (o ha avuto) fratelli o sorelle?

No

$\mathrm{Si}$, uno/a

$\mathrm{Si}$, due

$\mathrm{Si}, 3$ o più

\section{Questionario 6}

La preghiamo di rispondere alle seguenti domande.

La tua famiglia è proprietaria di un' automobile?

$\mathrm{Si}$, una

$\mathrm{Si}$, due o più

No

La casa dove la tua famiglia vive é:

Affittata

Di proprietà

Altro

\section{Questionario 7}

Quale è il tuo stato lavorativo:

Lavoratore dipendente

Lavoratore autonomo

Disoccupato in cerca di lavoro

Studente

Pensionato

Inoccupato (inabile al lavoro o non in cerca di lavoro) 


\section{Questionario 8}

In generale, diresti che la maggior parte delle persone siano degne di fiducia o che occorra essere molto attenti nel fidarsi con le persone?

Occorre stare molto attenti

Si può avere fiducia della maggior parte delle persone

Non so

Pensa, che la maggior parte delle persone approfitterebbe di te avendone la possibilità o cercherebbero di essere onesti? Ti prego di segnare la tua risposta nella tabella sottostante dove $1=$ "le persone approfitterebbero di me" e 10="le persone cercherebbero di essere oneste".

$\{$ Tabella con valori discreti tra 1 e 10$\}$

\section{Questionario 9}

Le nominerò una serie di organizzazioni. Per ciascuna di esse, potrebbe dirmi quanta fiducia ha in esse: molta fiducia, abbastanza fiducia, non molta fiducia, nessuna fiducia.

Associazioni e gruppi legati alla chiesa:

molta fiducia

abbastanza fiducia

non molta fiducia

nessuna fiducia

Associazioni o gruppi sportivi e per il tempo libero:

\{Stesse opzioni che per la domanda precedente\}

Associazioni e organizzazioni educative, musicali o artistiche:

\{Stesse opzioni che per la domanda precedente\}

\section{Sindacati:}

\{Stesse opzioni che per la domanda precedente\} 


\section{Partiti Politici:}

\{Stesse opzioni che per la domanda precedente\}

\section{Organizzazioni Ambientaliste:}

\{Stesse opzioni che per la domanda precedente\}

\section{Organizzazioni professionali:}

\{Stesse opzioni che per la domanda precedente\}

\section{Organizzazioni umanitarie o caritatevoli:}

\{Stesse opzioni che per la domanda precedente\}

Organizzazioni e associazioni di consumatori:

\{Stesse opzioni che per la domanda precedente\}

\section{Unione Europea:}

\{Stesse opzioni che per la domanda precedente\}

Hai effettuato donazioni di sangue negli ultimi 12 mesi?

Sí No

Non posso per ragioni mediche.

Hai votato alle ultime elezioni europee del 2014? Sí

No

Non avevo il diritto di voto.

Hai votato alle ultime elezioni referendarie del 2011? Sí

No

Non avevo il diritto di voto.

\section{Questionario 10}

Hai mai studiato presso una scuola o università straniera?

No 
Sí, per un periodo inferiore ai 3 mesi

Sí, per un periodo tra i 3 mesi e i 12 mesi

Sí, per un periodo tra i 12 e i 36 mesi

Sí, per più di 36 mesi

\section{Ha mai lavorato all'estero con un'attività indipendente o in qualità di dipen-} dente di azienda straniera?

No

Sí, per un periodo inferiore ai 3 mesi

Sí, per un periodo tra i 3 mesi e i 12 mesi

Sí, per un periodo tra i 12 e i 36 mesi

Sí, per più di 36 mesi

\section{Questionario 11}

La preghiamo di rispondere alla seguenti domande: Un cioccolatino e una caramella costano euro 1,10 in totale. Il cioccolatino costa 1 euro in più della caramella. Quanto costa la caramella? La risposta va espressa in CENTESIMI:

Se lanci una moneta non truccata due volte, quale è la probabilità in percentuale che esca Testa almeno una volta? La risposta va espressa in PERCENTUALE:

Se 5 macchinari in 5 minuti producono 5 portachiavi, quanto tempo ci mettono 100 macchinari a produrre 100 portachiavi? La risposta va espressa in MINUTI:

In un lago c'è una distesa di ninfee. Ogni giorno la distesa raddoppia di dimensione. Se in 48 giorni la distesa copre l'intero lago, quanti giorni ci vogliono per coprirne la metà? La risposta va espressa in GIORNI:

Se 3 commessi possono incartare 3 giocattoli in 1 ora, quanti commessi sono necessari per incartare 6 giocattoli in 2 ore? La risposta va espressa in COMMESSI:

Giulia e Sara stanno correndo in una pista circolare. Corrono alla stessa velocità ma Giulia 
è partita dopo. Quando Giulia ha percorso 5 giri, Sara ne ha percorsi 15. Quando Giulia ne avrà percorsi 30, quanti ne avrà percorsi Sara? La risposta va espressa in GIRI:

Il voto di Marco è sia il 15esimo voto più alto che il 15esimo voto più basso della classe. Quanti studenti ci sono nella sua classe? La risposta va espressa in STUDENTI:

In una squadra di atletica gli atleti alti tendono a vincere 3 volte di più di quelli bassi. Quest'anno la squadra ha vinto 60 medaglie. Quante medaglie sono state vinte dagli atleti bassi? La risposta va espressa in MEDAGLIE:

\section{Grazie}

Grazie per aver partecipato a questo studio.

Lo studio è terminato, ecco riportati qui di seguito in modo sintetico, i compensi che ricevi per ciascuna parte dello studio, e la somma finale che riceverai:

COMPENSO PER LA PRIMA PARTE $€ 2.20$

COMPENSO PER LA SECONDA PARTE $€ 1.92$

COMPENSO PER LA TERZA PARTE $€ 2.84$

COMPENSO PER LA QUARTA PARTE $€ 0.52$

COMPENSO PER LA QUINTA PARTE $€ 2.04$

COMPENSO DI PARTECIPAZIONE: $€ 5.00$

il totale che ti verrà pagato è: $€ 14.52$

Sei giunto alla fine dell'esperimento. Ti preghiamo di rimanere seduto finché non sarà chiamato il tuo numero. Il tuo codice è 5leaegg3 


\section{References}

Bigoni, M., S. Bortolotti, M. Casari, D. Gambetta, and F. Pancotto (2016). Amoral familism, social capital, or trust? the behavioural foundations of the italian north-south divide. The Economic Journal 126(594), 1318-1341.

Grimalda, G., N. Buchan, and M. Brewer (2015). Globalization, social identity, and cooperation: An experimental analysis of their linkages and effects. Technical report, Global Cooperation Research Papers.

Guiso, L., P. Sapienza, and L. Zingales (2011). Civic capital as the missing link. Handbook of social economics 1, 417-480.

Henrich, J., R. Boyd, S. Bowles, C. Camerer, E. Fehr, H. Gintis, and R. McElreath (2001). In search of homo economicus: behavioral experiments in 15 small-scale societies. American Economic Review 91(2), 73-78.

Henrich, J., S. J. Heine, and A. Norenzayan (2010). The weirdest people in the world? Behavioral and brain sciences 33(2-3), 61-83.

Herrmann, B., C. Thöni, and S. Gächter (2008). Antisocial punishment across societies. Science 319(5868), 1362-1367.

Lamba, S. and R. Mace (2011). Demography and ecology drive variation in cooperation across human populations. Proceedings of the National Academy of Sciences 108(35), 14426-14430.

Liang, F., R. Paulo, G. Molina, M. A. Clyde, and J. O. Berger (2008). Mixtures of g priors for bayesian variable selection. Journal of the American Statistical Association 103(481), $410-423$.

Pancotto, F. and S. Righi (2021). Reflectivity relates differently to pro sociality in naïve and strategic subjects. Scientific reports 11(1), 1-15.

Pancotto, F., S. Righi, and K. Takacs (2020). Voluntary play increases cooperation in the presence of punishment. Working Paper 3908319. 